Revista Brasileira de Estratégia e Relações Internacionais Brazilian Journal of Strategy \& International Relations

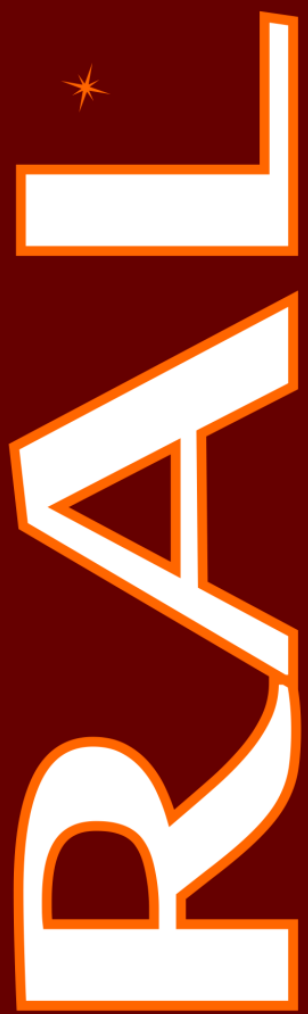

THE CRISIS TRANSFORMS THE INTERNATIONAL SYSTEM:

EMERGING SOUTHERN CONNECTIONS
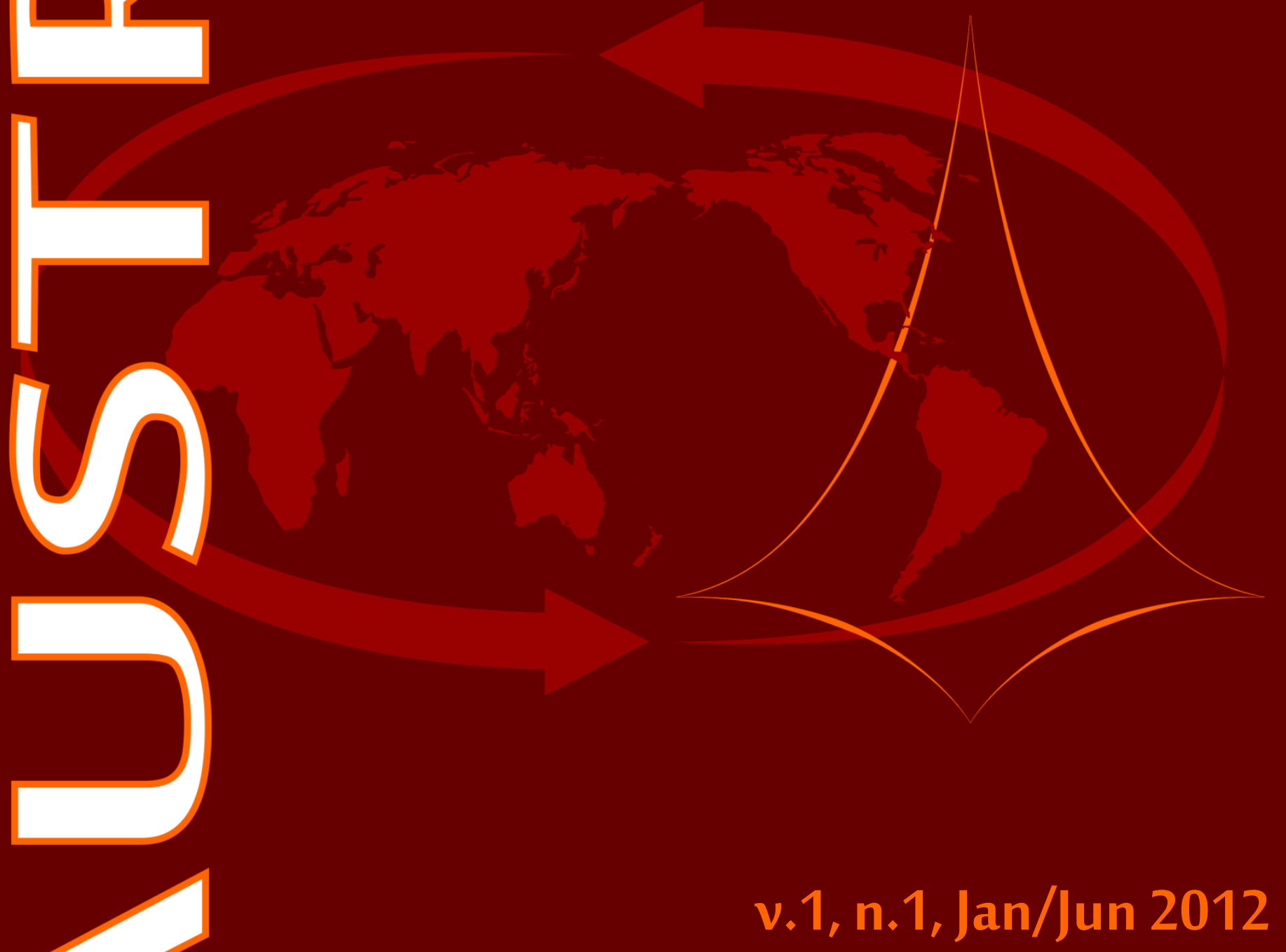


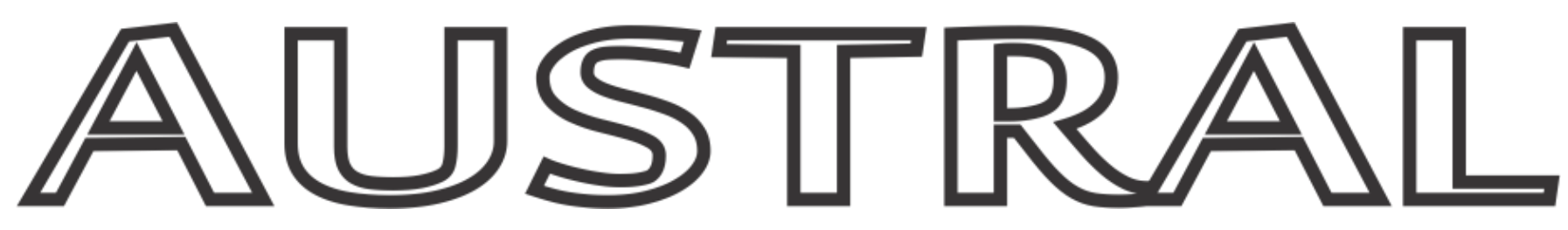

Revista Brasileira de Estratégia e Relações Internacionais Brazilian Journal of Strategy \& International Relations

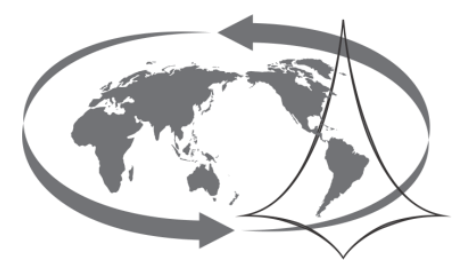

The Crisis Transforms the International System:

Emerging Southern Connections

Porto Alegre, n.1, v.1 | Jan/Jun. 2012
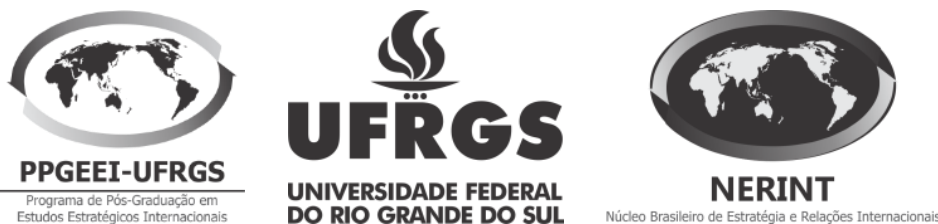
o presente trabalho foi realizado com 0 apoio do IPEA, entidade do Governo Brasileiro voltada para a pesquisa e desenvolvimento, e do Governo do Estado do Rio Grande do Sul.

This work was supported by IPEA, a research and development entity of the Brazilian Government, and by the Government of Rio Grande do Sul.
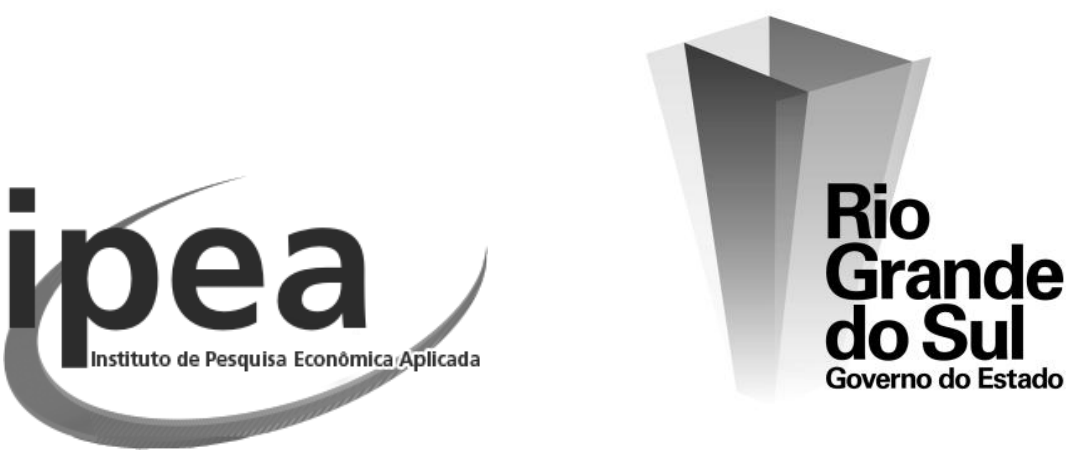


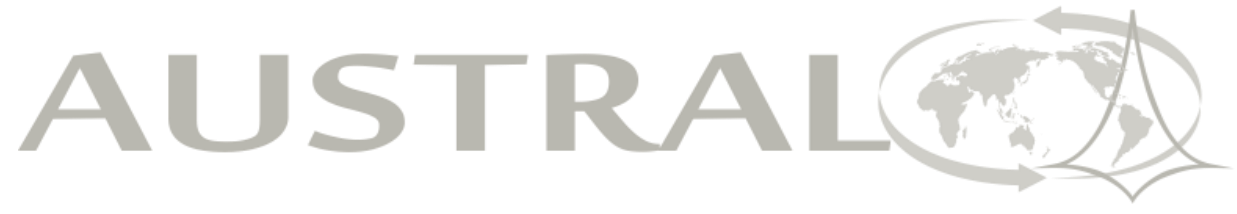

\section{SOBRE A REVISTA}

AUSTRAL: Revista Brasileira de Estratégia e Relações Internacionais é um veículo essencialmente acadêmico, ligado ao Programa de Pós-Graduação em Estudos Estratégicos Internacionais da Faculdade de Ciências Econômicas da Universidade Federal do Rio Grande do Sul/UFRGS e ao Núcleo Brasileiro de Estratégia e Relações Internacionais NERINT, Centro de pesquisa do Instituto Latino-Americano de Estudos Avançados da UFRGS. O enfoque pluralista está vinculado à contribuição para 0 debate sobre a transição da ordem política e econômica internacional, a partir de uma perspectiva dos países em desenvolvimento.

A revista publica artigos e resenhas inéditos nos idiomas inglês, espanhol e português cuja temática se situe na área das relações internacionais, com ênfase na política internacional dos países em desenvolvimento e que tenham como foco principal as Relações Sul-Sul, as questões de segurança, o desenvolvimento econômico, político e diplomático das nações emergentes e suas relações com as potências tradicionais. Tem como público alvo pesquisadores, especialistas e pós-graduandos da área de Relações Internacionais.

A Revista Austral procurará, na sua política de publicação, que cada número conste de, ao menos, um autor de cada grande continente austral (Ásia, América Latina, África) com vistas a estimular o debate e a articulação de conhecimento produzido nestas regiões. Todas as contribuições são submetidas à avaliação científica.

\section{ABOUT THE JOURNAL}

AUSTRAL: Brazilian Journal of Strategy \& International Relations is an essentially academic vehicle, linked to the International Strategic Studies Doctoral Program (PPGEEI) of the Faculty of Economics (FCE) of the Universidade Federal do Rio Grande do Sul (UFRGS) and to the Brazilian Center for International Relations and Strategic Studies (NERINT) - a research center of the Latin American Institute for Advanced Studies (ILEA/UFRGS). Its pluralist focus aims to contribute to the debate on the international political and economic order from the perspective of the developing countries.

The journal publishes original articles and book reviews in English, Portuguese or Spanish about themes that lie in the vast area of Strategy and International Relations, with special interest in issues related to developing countries and the South-South relations, their security issues, the economic, political and diplomatic development of emerging nations and their relations with the traditional powers. The journal's target audience consists of researchers, specialists and postgraduate students of International Relations.

The journal will try, through its publication policy, to ensure that each volume has at least one author from each of the great southern continents (Asia, Latin America, Africa), in order to stimulate the debate and the diffusion of the knowledge produced in these regions. All of the contributions will be subjected to a scientific review. 


\section{AUSTRAL}

Equipe Editorial Editorial Board

Editor Chefe Editor

Paulo Visentini (Universidade Federal do Rio Grande do Sul, Brasil)

Editor Adjunto Deputy Editor

Marco Cepik (Universidade Federal do Rio Grande do Sul, Brasil)

Comitê Editorial Editorial Board

André Luiz Reis da Silva (Universidade Federal do Rio Grande do Sul, Brasil)

André Moreira Cunha (Universidade Federal do Rio Grande do Sul, Brasil)

Adam Habib (University of Johannesburg, África do Sul)

Érico Esteves Duarte (Universidade Federal do Rio Grande do Sul, Brasil)

Fábio Morosini (Universidade Federal do Rio Grande do Sul, Brasil)

Gladys Lechini (Universidad Nacional de Rosário, Argentina)

Immanuel Wallerstein (Yale University, Estados Unidos da América)

Marcelo Milan (Universidade Federal do Rio Grande do Sul, Brasil)

Marco Cepik (Universidade Federal do Rio Grande do Sul, Brasil)

Ruchita Beri (Institute for Defence Studies an Analyses, Índia)

Assistente de Edição Edition Assistant

Guilherme Ziebell de Oliveira (Universidade Federal do Rio Grande do Sul, Brasil)

\section{Conselho Editorial Editorial Commitee}

Antônio Carlos Lessa (Universidade de Brasília, Brasil)

Amado Luiz Cervo (Universidade de Brasília, Brasil)

Antonio Jorge Ramalho (Universidade de Brasília, Brasil)

Bertrand Badie (Sciences Po, França)

Boris F. Martynov (Academia de Ciências da Rússia)

Carlos Arturi (Universidade Federal do Rio Grande do Sul, Brasil)

Chris Landsberg (University of Johannesburg, África do Sul)

Hüseyin Bağci (Middle East Technical University, Turquia)

Ilter Turan (Istanbul Bilgi University, Turquia)

José Ariosa Pérez (Universidad de la Habana, Cuba)

Liu Youfa (China Institute of International Studies, China)

Luis Augusto Estrella Faria (Universidade Federal do Rio Grande do Sul, Brasil)

Marcos Costa Lima (Universidade Federal de Pernambuco, Brasil)

Maria Regina Soares de Lima (IESP, Universidade do Estado do Rio de Janeiro, Brasil)

Mamoudou Gazibo (Université de Montréal, Canada)

Mehdi Parvizi Amineh (University of Amsterdam, Holanda)

Melissa H. Conley Tyler (Australian Institute of International Affairs, Austrália)

Mônica Hirst (Universidad Torcuato di Tella, Argentina)

Nikolai Mikhailov (Russkiy Mir Foundation, Rússia)

\section{Contato Contact}

Universidade Federal do Rio Grande do Sul - Faculdade de Ciências Econômicas Programa de Pós-Graduação em Estudos Estratégicos Internacionais

Av. João Pessoa, 52 sala 33A - CEP 90040-000 - Centro - Porto Alegre/RS - Brasil

Fone: +55 513308.3963 Fax: +55 513308.3963 Email: austral ${ }^{\circledR}$ ufrgs.br 


\section{AUSTRAL}

Volume 1, Número 1 (Jan-Jun 2012)

Apresentação

Celso Amorim

Editorial 9

Paulo Fagundes Visentini

O futuro do Mercosul 13

Samuel Pinheiro Guimarães

O Brasil de Lula: uma diplomacia global e afirmativa (2003-2010) 23

Paulo Fagundes Visentini

A virada russa para a América Latina 37

Yuri Paliev

Reordenando as Relações Internacionais: o Fórum de Cooperação China-

África.

Mamoudou Gazibo, Olivier Mbabia

A Política Externa do governo Jacob Zuma: associação ou dissociação?...... 79 Chris Landsberg

Cooperação Sul-Sul e a mudança de papel dos Estados do Golfo. 109 Kristian Coates UIrichsen

A crise financeira e a hegemonia do dólar.

Marcelo Milan

Parceiros

Normas de Submissão.

As opiniões expressas nos artigos publicados nessa revista são de responsabilidade de seus respectivos autores. 


\title{
APRESENTAÇÃO
}

\author{
Celso Amorim ${ }^{1}$
}

Vem em boa hora esta Austral: Revista Brasileira de Estratégia e Relações Internacionais. Em um mundo multipolar cujos contornos vão se delineando com rapidez por vezes desconcertante, é preciso acertar o passo da reflexão sobre a realidade internacional. Redefinir premissas, atualizar parâmetros e rever juízos tudo isso está na ordem do dia. O pensamento tradicional sobre Relações Internacionais é um campo aberto a esse trabalho. Se a década passada encerrou-se com o questionamento de um conjunto de enunciados sobre a economia global, a década que vai se abrindo pode testemunhar a inovação nas formas de pensar a política internacional.

Conceitos clássicos deverão ser reformulados para dar conta de fenômenos de tipo e alcance inéditos. Sem prejuízo do compromisso com a objetividade descritiva, a qualidade normativa das narrativas sobre o funcionamento da realidade internacional estará sob permanente escrutínio. Paz e guerra, diálogo e força, persuasão e influência, entre outros, compõem a constelação de ideias em que se travará esse debate a um tempo teórico e prático. E será preciso tomar parte nele a partir de perspectiva própria. A feliz escolha do nome desta revista, Austral, atesta sua identificação com esse propósito.

Perspectiva própria, mas não unívoca. A pluralidade de ideias e conceitos, marca da reflexão sólida, é o melhor ponto de partida para cogitar de nossa perspectiva sobre a ordem mundial.

Como democracia consolidada e economia em desenvolvimento, o Brasil tem sabido afirmar um ponto de vista independente sobre a ordem global neste princípio de século XXI. Em política externa, demonstramos que a solidariedade pode reforçar o interesse nacional, e que o Sul pode ter um papel construtivo e indispensável na formatação da ordem multipolar.

Isso não ocorreu de forma suave ou sem contestação. Como toda quebra de paradigma, a ruptura com ideias pré-concebidas provocou polêmica e gerou críticas,

\footnotetext{
${ }^{1}$ Ministro da Defesa e ex-Ministro das Relações Exteriores do Brasil. (austral@ufrgs.br)
} 
umas menos fundadas que outras. Mas hoje mesmo aqueles que criticaram várias das posturas adotadas têm que reconhecer a inédita posição de destaque do Brasil no cenário internacional. E o papel da política externa nessa ascensão tem sido assinalado por analistas de todas as partes do mundo.

Atitudes como as que o Brasil tomou nas negociações da ALCA e da OMC, o impulso dado à integração sul-americana, a aproximação com a África, a formação de grupos como o BRICS e o IBAS, além de posição desassombrada em temas como o Oriente Médio e a busca de solução pacífica para a questão do programa nuclear iraniano, fizeram do nosso país um ator respeitado, cuja participação é crescentemente requisitada.

O retorno do tema da defesa à agenda nacional nos últimos anos dá respaldo a essa postura. Costumo dizer que país pacífico não é sinônimo de país indefeso. Com a Estratégia Nacional de Defesa, o Brasil aceitou a tarefa exigente, e insubstituível, do provimento de seus próprios meios de defesa. Ao fortalecê-los, o Brasil não só diminui suas vulnerabilidades frente às ameaças potenciais de um cenário internacional crescentemente instável, mas também contribui para reforçar a multipolaridade orgânica, que deve ser a base de uma governança mundial mais segura e mais justa.

Abordando temas estratégicos e de segurança, a revista Austral contribuirá para o aprofundamento da reflexão sobre esses e outros assuntos de enorme valor para a política externa, a defesa e o desenvolvimento de nosso país.

Que venha o debate! 


\section{EDITORIAL}

\section{Paulo Fagundes Visentini ${ }^{l}$}

A política externa do Brasil atingiu, desde o início do século XXI, uma presença realmente mundial, que superou qualitativa e quantitativamente os grandes avanços da Política Externa Independente (1961-64) e dos momentos marcantes do Regime Militar (1964-85), como o Pragmatismo Responsável e o Universalismo. Quantitativamente, a diplomacia brasileira se fez presente, além das regiões e parceiros tradicionais, nas pequenas nações africanas, asiáticas e do mundo árabe, nas ex-repúblicas soviéticas e até nos distantes arquipélagos do Oceano Pacífico. Cabe aqui destacar o papel decisivo desempenhado pelo Ministério das Relações Exteriores (Itamaraty) e por outros órgãos governamentais neste processo.

Do ponto de vista qualitativo, tal presença ganhou notável intensidade política, econômica e programática com a participação "ativa, afirmativa e propositiva" em importantes fóruns internacionais e organismos multilaterais. Dentre eles podem ser mencionados a criação do Fórum de Dialogo IBAS (Índia, Brasil e África do Sul) e do G-20 Comercial, a participação no BRICS, no G-20 Financeiro, além da Organização Mundial do Comércio (OMC) e das Nações Unidas $(\mathrm{ONU})$. Este avanço diplomático foi acompanhado pela expansão mundial e pelo crescimento da economia brasileira, que ultrapassou o PIB de vários países da OCDE.

O Brasil recebeu o status de Parceiro Estratégico da União Européia e celebrou o mesmo vínculo com potências emergentes como a China, a Índia, a África do Sul e outras importantes nações. A integração sul-americana, com o Mercosul e a UNASUL, avançou de forma constante, inclusive com iniciativas extra-regionais, como a Cúpula América do Sul-África (ASA) e América do Sul-Países Árabes (ASPA). A Cooperação Sul-Sul foi outro eixo da diplomacia brasileira, com intensa presença na África (onde o então presidente Lula realizou 11 viagens, visitando 29 nações) e Ásia. Aliás, a projeção e prestígio mundiais do ex-presidente Luiz Inácio

1 Coordenador do Programa de Pós-Graduação em Estudos Estratégicos Internacionais da Universidade Federal do Rio Grande do Sul e Professor Titular do curso de Relações Internacionais. Pós-Doutorado pela London School of Economics e pesquisador do CNPq. (paulovi@ufrgs.br) 
"Lula" da Silva, ao longo de seus dois mandatos, representa um elemento inédito na diplomacia brasileira.

Ainda que tais avanços tenham sido abordados no exterior e nas diversas revistas científicas nacionais, carecíamos ainda de um veículo bilíngue (português ou espanhol e inglês), que estivesse focado exclusivamente na análise de tal performance. Ao mesmo tempo, fazia falta um instrumento que nos colocasse em contato direto com os demais centros de reflexão nos países em desenvolvimento, com os quais nos últimos anos estabelecemos contatos de alto nível. Por fim, com os acadêmicos e instituições que, no Norte, pensam criticamente as intensas transformações por que está passando o sistema mundial.

Assim, desde a criação do NERINT (Núcleo Brasileiro de Estratégia e Relações Internacionais), em 1999, a equipe de pesquisadores planejava a criação de uma revista científica que veiculasse suas pesquisas, pontos de vista e estabelecesse um diálogo com acadêmicos de outras nações e com membros do próprio corpo diplomático brasileiro. Para tanto, foram sendo feitos contatos no país e no exterior, ao longo dos anos. Ela deveria refletir a perspectiva do mundo em desenvolvimento, o "Sul", e este sonho antigo agora se torna realidade, nascido de uma cuidadosa, longa e pensada preparação.

Nesta perspectiva, estamos apresentando ao público brasileiro e estrangeiro a revista AUSTRAL, Brazilian Journal of Strategy and International Relations/ AUSTRAL, Revista Brasileira de Estratégia e Relações Internacionais, uma iniciativa do Programa de Pós-Graduação em Estudos Estratégicos Internacionais (PPGEEI) e do Núcleo Brasileiro de Estratégia e Relações Internacionais (NERINT) do Instituto Latino-Americano de Estudos Avançados da Universidade Federal do Rio Grande do Sul (UFRGS), em Porto Alegre. Austral significa Sul em português, em espanhol e em inglês. A revista tem frequência semestral, está disponível em formato eletrônico e impresso (www.ufrgs.br/austral) e é um desdobramento de outra iniciativa de sucesso, a revista bimestral Conjuntura Austral (www.ufrgs.br/ConjunturaAustral).

Trata-se de uma publicação essencialmente acadêmica voltada a temas políticos e econômicos internacionais, com ênfase na diplomacia dos países em desenvolvimento, que normalmente recebem atenção limitada ou etnocêntrica por parte das grandes revistas internacionais. $O$ foco principal da publicação são as Relações Sul-Sul, as questões de segurança, o desenvolvimento econômico, político e diplomático das nações emergentes e suas relações com as potências tradicionais, num contexto de crise e transição da ordem internacional. O Conselho Editorial 
conta com renomados acadêmicos de todos os continentes, especializados nos diversos temas, e a revista está aberta à contribuição de todos que desejam se somar a este esforço de análise da política externa brasileira e da transformação do sistema internacional.

Agradecemos o apoio do IPEA e o inestimável apoio do Governo do Estado do Rio Grande do Sul e sua Assessoria Internacional, para a publicação das duas edições iniciais da nova Revista. Agradecemos, também, aos professores Marco Cepik, Editor Adjunto da revista, e André Reis da Silva, pela colaboração técnica no projeto, bem como a toda equipe que trabalhou na edição e tradução, em particular ao incansável acadêmico de Relações Internacionais Guilherme Ziebell de Oliveira.

Paulo Fagundes Visentini 


\title{
O FUTURO DO MERCOSUL
}

\author{
Samuel Pinheiro Guimarães ${ }^{l}$
}

A análise da situação do Mercosul, de seus objetivos e das estratégias para alcançá-los, é de especial relevância no momento em que se vem de comemorar os vinte anos da assinatura, em 26 de março de 1991, do Tratado de Assunção, em plena e extraordinária crise e transformação política e econômica mundial.

Em 1991, era hegemônico o pensamento neoliberal, em um cenário econômico de grande otimismo. Era a Nova Ordem Mundial, anunciada pelo presidente G. H. Bush, a era da globalização, do fim das fronteiras, do fim da História, do progresso ilimitado para todos os Estados e para todos os indivíduos. Era o mundo unipolar, pacífico e próspero.

Esse pensamento neoliberal, que veio a ser articulado no Consenso de Washington e impulsionado pelas políticas dos países desenvolvidos nos organismos e negociações internacionais e em suas relações bilaterais com os Estados da América Latina, viria a se refletir, em decorrência dessas pressões externas e até por convicção das elites dirigentes, nas políticas domésticas, econômicas e sociais, dos quatro Estados do Mercosul.

Apesar das naturais diferenças entre as situações em que se encontravam Estados e sociedades naquele momento e do grau de radicalismo com que foram implementadas, essas políticas todas tinham como principal objetivo reduzir o Estado a seu mínimo, através de programas de privatização, de desregulamentação e de abertura externa para bens e capitais, muitas vezes adotados de forma unilateral, sem negociação, como "contribuição voluntária" ao progresso de globalização.

Em 1991, a situação política internacional estava marcada pela desintegração da União Soviética, pelo fim dos regimes socialistas da Europa Oriental, pelo desprestígio do socialismo como sistema político e econômico, pela expansão (voluntária ou "estimulada") de regimes democráticos, pelo fim aparente dos

\footnotetext{
${ }^{1}$ Alto Representante do Mercosul. (austral@ufrgs.br)
} 
conflitos regionais, pela "ressurreição" das Nações Unidas e, finalmente, pela hegemonia dos Estados Unidos.

Em 2012, a economia mundial se caracteriza pelo aumento da distância entre países desenvolvidos e subdesenvolvidos, pela expansão da globalização e das mega empresas multinacionais e, de outro lado, passa pela sua mais profunda crise desde 1929, a qual se originou em uma tendência à superprodução, à extensão excessiva do crédito e, finalmente, em um enorme movimento especulativo, desencadeado por bancos, fundos de investimento, auditoras e corretoras, permitido pela globalização e pela profunda desregulamentação nacional e internacional dos sistemas financeiros. A crise eclodiu nos Estados Unidos e se espraiou pelos sistemas financeiros dos demais países desenvolvidos, enquanto se atribuiu aos países emergentes, de forma indistinta, a capacidade de manter algum crescimento positivo da economia mundial. Enquanto os países ocidentais desenvolvidos se encontram mergulhados em suas crises, que já afetam a unidade europeia, a China surge como a segunda maior potência econômica do mundo.

Em 2012, o panorama político-militar internacional se caracteriza pelo desenrolar de guerras em países islâmicos, com a expansão dos poderes da OTAN para muito além de sua área de competência; pela luta contra um inimigo difuso, o terrorismo; pela eclosão, imprevista, de movimentos populares contra ditaduras árabes tradicionalmente apoiadas, e às vezes até financiadas, pelas potências ocidentais; pela intervenção das potências ocidentais, a pretexto humanitário, nos assuntos internos de Estados mais fracos; pelo ressurgimento da xenofobia e do racismo, em especial na Europa, com reflexos sobre imigrantes sul-americanos; pela crescente sofisticação e automação das forças militares das grandes potências e pelo seu esforço em desarmar, inclusive em termos convencionais, os Estados mais fracos e já desarmados.

Este cenário político-militar estará sendo cada vez mais transformado pela expansão geográfica da presença política, e no futuro militar, da China, a partir de sua crescente influência econômica, em sua qualidade de maior economia, maior potência exportadora e importadora, segundo maior destino de investimentos internacionais, de sua crescente capacidade científica e tecnológica, de sua situação de maior detentora de reservas internacionais e de maior investidora em títulos do Tesouro americano. Apesar de todas as dificuldades e desafios a trajetória econômica e política chinesa tende a não sofrer radicais alterações devido às características de seu sistema político colegiado e de ascensão gradual dos membros do Partido Comunista às posições de alta responsabilidade no Bureau Político do Comitê Central. 
A emergência da China como a maior potência econômica do mundo, e possivelmente, em breve, como a segunda maior potência política e militar, tem extraordinárias consequências para a América do Sul, mas muito especialmente para os Estados do Mercosul.

Em especial para o Mercosul, na medida em que certos governos da América do Sul tomaram a decisão, de grande importância para seus países e para o futuro político e econômico da América do Sul, que foi a de se inserir, inicialmente, no sistema econômico norte-americano, através da assinatura de amplos acordos econômicos, chamados impropriamente "de livre comércio", e, em seguida, na economia mundial, através da negociação de acordos, ai sim de livre comércio, com a União Européia e com muitos outros países, entre eles a China.

Esses países sul-americanos optaram por uma política de inserção irrestrita na economia global e abdicaram da possibilidade de utilizar diversos instrumentos de promoção do desenvolvimento, em especial importantes no caso de países subdesenvolvidos, com populações expressivas, com alto grau de urbanização, com grandes disparidades sociais e econômicas. E em consequência, abdicaram de uma participação mais intensa em um processo de integração regional sul-americano pela impossibilidade de participar de uma união aduaneira regional e de políticas regionais de natureza industrial que permitam o fortalecimento das empresas produtivas instaladas em seus territórios. Assim, a retórica presente em todos os encontros acadêmicos e políticos sobre a aspiração, a possibilidade e os benefícios de uma futura integração sul-americana deve ser vista à luz desta realidade atual.

O impacto da China sobre a economia dos países do Mercosul, que já é grande, se tornará extraordinário.

A economia chinesa vem crescendo a $10 \%$ ao ano, em média, nos últimos trinta anos, desafiando os recorrentes prognósticos negativos dos especialistas. Sua economia moderna é integrada por cerca de 300 milhões de indivíduos, com um déficit crescente de alimentos para uma população que melhora e diversifica seu padrão alimentar, sem suficientes terras aráveis e água para a irrigação em grande escala, (ainda que haja a possibilidade de dessalinização da água do mar e de desenvolvimento de tecnologias agrícolas adequadas às suas regiões inóspitas), com uma demanda voraz e um déficit de minérios muito significativo, e com um déficit energético crescente, apesar dos ambiciosos programas de expansão de seus sistemas eletro-nuclear e eólico. A incorporação gradual de mais de um bilhão de chineses, hoje no campo e em atividades de baixa produtividade, ao setor moderno da economia tornará a China o maior mercado do mundo, superior ao mercado americano e europeu somados. 
Apesar de a demanda chinesa por minérios, por alimentos e por energia poder ser suprida por outras regiões, em especial a África, a América do Sul e os países do Mercosul estão em condições especiais para atendê-la, como, aliás, já vem fazendo com suas exportações de soja e de minério de ferro, entre outros produtos.

A demanda chinesa por minérios, petróleo e produtos agrícolas contribui, de forma expressiva, para o aumento dos preços mundiais desses produtos, para um impulso inflacionário em todos os países, para a geração de grandes receitas cambiais nos países do Mercosul, e para a consequente valorização de suas moedas nacionais, afetadas pelo influxo simultâneo do excesso de moeda ofertada pelos Estados Unidos, através de sua política de "monetary easing".

Por outro lado, a China, que se constituiu, inicialmente, em uma enorme plataforma de produção e exportação das megaempresas multinacionais, passou, através de suas políticas comerciais, industriais e de transferência de tecnologia, a criar e desenvolver suas empresas de capital chinês, capazes de participar do mercado mundial, nos mais diversos setores, com produtos dos mais simples aos mais complexos, com custos de produção e preços de exportação altamente competitivos.

A própria situação da China e sua estratégia de desenvolvimento afetará da forma mais profunda as perspectivas de desenvolvimento de cada país do Mercosul, colocará em cheque suas políticas comerciais, industriais e tecnológicas, pautadas pelas normas da OMC, negociadas e adotadas em um contexto internacional diverso, e o próprio futuro do Mercosul, como esquema de desenvolvimento econômico, de transformação produtiva e de desenvolvimento social da região.

De um lado, a demanda chinesa por produtos primários e, de outro lado, sua oferta de produtos industriais a baixo preço, diante da ortodoxia de política econômica de certos países (centrada em uma excessiva preocupação com o combate à inflação e com o equilíbrio fiscal) e de seu baixo dinamismo tecnológico poderá levar, se não vierem a ser formuladas e implementadas firmes e permanentes políticas industriais de agregação de valor aos produtos primários em forte demanda, a uma especialização na produção primária para exportação, e à conquista pela China dos mercados de produtos industriais dos sócios do Mercosul e dos demais países da América do Sul .

Esta situação tenderia a se agravar com a superação da crise econômica nos países altamente industrializados, que provocou a redução temporária de sua demanda por insumos primários. Com a retomada de seu crescimento industrial e de renda, esses países passarão a exercer uma pressão adicional ainda maior sobre os 
mercados de produtos primários, agrícolas e minerais, com alta possibilidade de aprofundar o processo de especialização regressiva dos países da América do Sul e em especial do Mercosul, que inclui as duas maiores economias industriais da região.

Em sociedades cada vez mais urbanizadas e com populações expressivas, sob o impacto permanente da propaganda agressiva de estímulo ao consumo, essa especialização regressiva levaria a uma oferta de empregos industriais nessas sociedades insuficiente para atender à crescente demanda decorrente do crescimento demográfico e da necessidade de absorver os estoques de mão de obra secularmente subempregados e desqualificados. Os efeitos sociais dessa insuficiente geração de empregos urbanos seriam de extrema gravidade.

Esse cenário afetaria profundamente as perspectivas e as possibilidades de integração mais profunda entre os Estados do Mercosul na medida em que esta integração depende da vinculação cada vez maior entre suas economias (e consequente vinculação política) o que somente é possível pelo intercâmbio de produtos industriais pois, no setor agrícola, além da menor gama de produtos típica desse setor, as produções dos quatro países são, em larga medida, concorrentes. Suas economias ficariam gradual ou até mesmo rapidamente cada vez mais isoladas umas das outras e o processo de integração mais profunda ficaria definitivamente abalado e reduzido a esforços de cooperação em setores importantes, porém limitados.

\section{O desafio das assimetrias}

As assimetrias entre os Estados do Mercosul, que são notáveis em território e população, aspectos o primeiro fixo e o segundo de lenta transformação, mas que tem, todavia, grande importância econômica, vem crescendo rapidamente em termos de grau de diversificação produtiva, de dinamismo tecnológico e de dimensão dos respectivos parques produtivos.

A dinâmica dessas assimetrias, deixada ao sabor das forças de mercado, em uma união aduaneira e em uma área de livre comércio, na inexistência de esquemas corretivos, leva a um grau de desenvolvimento cada vez mais distinto e, portanto, a fricções, a frustrações e a ameaças permanentes à coesão do Mercosul, com todas as consequências para a capacidade, tanto dos Estados maiores mas em especial dos menores, de defender e de promover seus interesses em um cenário internacional cada vez mais caracterizado, apesar da crise, pela expansão de grandes blocos de países, nas Américas, na Europa e na Ásia. 
A redução das assimetrias é essencial para que as economias e as sociedades possam se beneficiar de forma equitativa do processo de integração. As assimetrias que, em termos concretos, correspondem a grandes diferenças de infraestrutura física e social, de capacitação da mão de obra e de dimensão das empresas, fazem com que os investimentos privados não possam se distribuir de forma mais harmônica dentro do espaço comum, que a geração e a qualidade de empregos seja desigual e que, portanto, seja desigual a geração de renda e o bem estar nas diversas sociedades.

Outros esquemas de integração, como a União Europeia, desde sua origem em 1958, se preocuparam com a existência e os efeitos de diferentes níveis de desenvolvimento entre os Estados que deles participavam e com a necessidade de promover o desenvolvimento mais acelerado dos países mais atrasados para tornar mais equilibradas as oportunidades dentro do espaço econômico comum. Lançaram mão de vários programas, basicamente de transferência de recursos, com o objetivo de nivelar a economia dos Estados que foram se agregando à União Europeia e que se encontravam em diferentes estágios de desenvolvimento. $O$ processo de reunificação das duas Alemanhas foi e é um exemplo de grande transferência de recursos que chega a atingir trilhões de dólares com o objetivo de nivelar duas economias e sociedades que se integram.

Devido à doutrina neoliberal e a seus objetivos implícitos, que presidiram à criação do Mercosul, inicialmente julgou-se e afirmou-se que as dimensões assimétricas dos Estados não afetariam o desenvolvimento de cada um deles e que a simples integração comercial automática, sem levar em conta de forma adequada essas assimetrias, permitiria a cada um deles usufruir, de forma igual ou semelhante, dos benefícios decorrentes do processo de integração.

Vinte anos depois do Tratado de Assunção há uma aceitação generalizada de todos os Governos da importância e das consequências de toda ordem das assimetrias entre os Estados e da necessidade de enfrentá-las com programas eficazes, cujo montante de recursos até agora alocados são absolutamente insuficientes para a dimensão da tarefa.

Algumas afirmações básicas podem ser feitas sobre a possibilidade de êxito no enfrentamento do desafio de redução das assimetrias, indispensável para a coesão e o futuro econômico e político do Mercosul:

a. sem a compreensão generosa (e, aliás, de seu próprio interesse, econômico e político) dos Estados maiores, que deve se refletir 
em suas contribuições financeiras para os diversos programas, em especial para o FOCEM (Fundo para a Convergência Estrutural do Mercosul) pode-se continuar a enfatizar retoricamente a importância das assimetrias mas elas não se reduzirão;

b. sem a construção da infraestrutura de energia e de transportes nos Estados menores as assimetrias não se reduzirão e

c. nenhum programa ou política comunitária em nenhuma das diversas áreas de integração poderá ir adiante sem a a criação de instrumentos financeiros assimétricos de financiamento desses programas e políticas.

\section{Ampliação geográfica do Mercosul}

Em um cenário internacional caracterizado pela ampliação de grandes blocos de países fortalecidos, a despeito da crise do euro, a capacidade do Mercosul de defender e de promover os interesses de seus Estados depende de seu fortalecimento econômico e político.

Do ponto de vista econômico e social, o fortalecimento do Mercosul resultará do desenvolvimento produtivo de cada uma das quatro economias nacionais, de sua integração física e comercial, da redução significativa das disparidades em cada uma das sociedades, de seu dinamismo tecnológico, da redução das vulnerabilidades externas de cada um de seus membros.

Do ponto de vista político, o fortalecimento do Mercosul como bloco depende de um lado de uma coordenação cada vez mais estreita de seus membros e, de outro lado, do número de Estados soberanos que o integram, Estados que, por esta razão, tem interesse em coordenar suas ações, como membros de um bloco, nas negociações e foros internacionais e diante de crises e iniciativas de terceiros Estados, em especial daqueles mais poderosos.

A ampliação geográfica do Mercosul significa a adesão de novos membros. Por causa de decisões que tomaram no passado, não podem, no momento atual, fazer parte do Mercosul Estados que assinaram acordos de livre comércio com outros Estados ou blocos, tais como a União Europeia, e que, por esta razão, aplicam tarifa zero às importações provenientes daqueles Estados ou blocos e que, assim, não poderiam adotar e aplicar a Tarifa Externa Comum do Mercosul. 
A ampliação geográfica do Mercosul teve início com o processo de adesão da Venezuela. A participação integral da Venezuela no Mercosul é da maior importância política e econômica, dada a riqueza de recursos minerais e energéticos do país e de sua decisão de desenvolver industrialmente sua economia. Depende ela agora somente de decisão do Senado Paraguaio, já tendo sido aprovada pela Argentina, Brasil, Uruguai e Venezuela.

Além da Venezuela, poderiam, em princípio, ingressar no Mercosul a Bolívia, o Equador, o Suriname e a Guiana. A possibilidade de Estados extra-regionais, isto é, situados fora da América do Sul, ingressarem no Mercosul é reduzida.

É de todo o interesse dos Estados do Mercosul criar as condições as mais favoráveis possíveis ao ingresso da Bolívia, do Equador, do Suriname e da Guiana como membros plenos no Mercosul e de fortalecer as relações com todos os demais países da América do Sul que, aliás, já são Estados associados, para que, no futuro, caso desejem ingressar no Mercosul, este ingresso seja mais fácil e eficaz, política e economicamente.

\section{O Mercosul como mecanismo de desenvolvimento regional}

À época da criação do Mercosul, existia a convicção nos governos dos Presidentes Menem, Collor, Rodrigues e Lacalle, de que a execução das políticas preconizadas pelo Consenso de Washington, isto é, de desregulamentação, de privatização, de abertura ao capital estrangeiro e de remoção das barreiras ao comércio, seriam suficientes para promover o desenvolviment o econômico e social.

O Mercosul foi criado em 1991 para ser um esquema de liberalização comercial, como uma etapa de um processo "virtuoso" de eliminação de barreiras ao comércio e de plena inserção na economia internacional, e não para ser um organismo de promoção do desenvolvimento econômico nem dos Estados isolados nem em conjunto.

A implementação do Tratado de Assunção, ao não levar em conta de forma adequada as diferenças entre os países e o impacto econômico e político dos deslocamentos econômicos causados pela redução de tarifas, levou a todo tipo de esquemas "provisórios", tais como o acordo automotivo e as exceções à TEC, periodicamente renovadas, para bens da capital e de tecnologia de informação, e os acordos, muitas vezes informais, de organização do comércio em certos setores empresariais. 
A transformação do Mercosul de uma simples união aduaneira e área de livre comércio imperfeitas em um esquema de desenvolvimento regional equilibrado e harmonioso dos quatro Estados, o que significa a eliminação das assimetrias e a gradual construção de uma legislação "comum", exigiria:

a) o reconhecimento enérgico das assimetrias, cuja realidade se verificaria pela constituição de fundos comuns assimétricos, com recursos adequados, em cada área de integração, para financiar projetos, inclusive de harmonização gradual da legislação;

b) a garantia de condições para permitir políticas de promoção do desenvolvimento industrial de cada Estado;

c) a celebração de acordos em setores industriais relevantes, semelhantes ao acordo automotivo;

d) a criação de mecanismos que impeçam a “desorganização dos mercados" nacionais e, ao mesmo tempo, evitem o desvio de comércio em favor de países não-membros do Mercosul;

e) o acesso das empresas de capital nacional, sediadas nos quatro Estados, aos organismos nacionais de financiamento de qualquer um dos quatro Estados do Mercosul;

f) a harmonização da legislação dos quatro Estados em todas as áreas de integração.

A crise econômica internacional, a estratégia e as políticas de desenvolvimento implementadas pela China, os programas implementados pelos países industrializados para enfrentar a crise e a verdadeira "suspensão", na prática, das normas incluídas nos diversos acordos da OMC, "negociados" à época da hegemonia do pensamento neo liberal, criam um ambiente propício à adoção deste elenco de medidas. 


\section{RESUMO}

Este artigo analisa a situação do Mercosul, de seus objetivos e das estratégias para alcançá-los, no contexto de comemoração dos vinte anos da assinatura, em 26 de março de 1991, do Tratado de Assunção e de plena e extraordinária crise e transformação política e econômica mundial.

\section{PALAVRAS-GHAVE}

Mercosul; Crise Econômica Mundial; Transformação Política. 


\title{
O BRASIL DE LULA: UMA DIPLOMACIA GLOBAL E AFIRMATIVA (2003-2010)
}

\author{
Paulo Fagundes Visentini ${ }^{l}$
}

O Brasil é o quinto país do mundo em população e em superfície territorial e chegou a ser a décima economia durante o Regime Militar (1964-1985), depois declinando durante a abertura à globalização neoliberal e o encerramento da Guerra Fria. Durante o Governo Luis Inácio "Lula" da Silva (2003-2010), todavia, o Brasil ganhou notável importância na política e na economia mundiais, alcançando a oitava posição. A diplomacia brasileira alcançou uma posição realmente global e a economia ganhou dinamismo e estabeleceu vínculos em todos os continentes. Como isto foi posssível?

\section{As Bases do Governo Lula e de sua Política Externa}

A esmagadora vitória do candidato da centro-esquerda à presidência, Luiz Inácio "Lula" da Silva, ocorreu de forma tranqüila, contrariando as especulações catastróficas e mostrando a existência de certas linhas de continuidade. $O$ novo governo, o primeiro liderado por uma pessoa oriunda da classe trabalhadora em 500 anos, estava apoiado num amplo leque de sustentação, do qual faziam parte as bases sindicais do PT, segmentos da classe média castigados pelo modelo econômico, setores das Forças Armadas, do Estado e políticos nacionalistas, além de empresários interessados em um mercado interno forte. Essa base incentivava a adoção de medidas capazes de reduzir o imenso déficit social legado pela era neoliberal, possibilitando a geração de empregos, a redução da criminalidade e da violência e o reforço de uma economia de produção.

Muitos esperavam um comportamento internacional baseado em visões ideológicas e um presidente despreparado. Mas o que se viu foi uma diplomacia dotada de sentido tático-estratégico, de visão de longo alcance e um presidente que se

1 Coordenador do Programa de Pós-Graduação em Estudos Estratégicos Internacionais da Universidade Federal do Rio Grande do Sul e Professor Titular do curso de Relações Internacionais. Pós-Doutorado pela London School of Economics e pesquisador do CNPq. (paulovi@ufrgs.br) 
revelou uma liderança carismática de nível mundial. Como vimos, embora o atual curso da política externa brasileira tivesse início já no segundo governo Fernando Henrique Cardoso, não houve, naquele momento, alterações significativas. O expresidente não possuía a vontade e a base política necessárias para uma mudança que ultrapassasse um tímido discurso crítico e uma inflexão limitada. A posse de Lula mudou esta situação e a política externa brasileira tem conhecido notável desenvolvimento e protagonismo, superando muitas expectativas.

O Embaixador Celso Amorim voltou a chefiar o Ministério das Relações Exteriores e, significativamente, o Embaixador Samuel Guimarães tornou-se Secretário Geral, exercendo um papel fundamental, sempre atacado por interesses estrangeiros, elementos da gestão anterior e setores da mídia ligados a ambos. Para a concretização da nova estratégia, as relações internacionais do governo Lula foram dotadas de três dimensões: uma diplomacia econômica, outra política e um programa social. A primeira dimensão é realista, a segunda de resistência e afirmação e a terceira propositiva. Trata-se de um projeto amadurecido por mais de uma década, e não uma política voluntarista, e tem demonstrado estar adequada à correlação de forças existente no país e no mundo.

Em relação ao primeiro aspecto, é necessário manter abertos os canais de negociação com o Primeiro Mundo, obtendo recursos (investimentos e tecnologia), negociando a dívida externa e sinalizando que o governo deseja cumprir os compromissos internacionais sem nenhuma ruptura brusca ou quebra do modelo macroeconômico. Mas essa dimensão "caudatária" da ordem mundial é compensada pelo reforço da postura negociadora junto aos organismos econômico-financeiros multilaterais e por ajustes internos para reforçar a capacidade de atuação do Estado e o mercado interno.

A diplomacia política, por sua vez, representa um campo de reafirmação dos interesses nacionais e de um verdadeiro protagonismo nas relações internacionais, com a intenção real de desenvolver uma diplomacia ativa e afirmativa, encerrando uma fase de estagnação e esvaziamento. $O$ governo Lula devolveu ao Itamaraty a posição estratégica que anteriormente ocupara na formulação e execução da política exterior do Brasil. Além disso, foi promovido amplo redimensionamento do Itamaraty: adoção de políticas afirmativas sem quotas, ampliação do número de diplomatas, abertura de numerosas embaixadas na África e na Ásia e maior abertura da diplomacia à sociedade civil e à academia.

Finalmente, o projeto interno do governo Lula também tem um significativo impacto internacional na medida em que suas propostas sociais vão ao encontro da agenda que busca corrigir as distorções criadas pela globalização centrada apenas em 
comércio e investimentos livres. A campanha de combate à fome representa o elemento simbólico que sinaliza a construção de um modelo sócio-econômico alternativo, respondendo à crise da globalização neoliberal.

Medidas como a revalorização do mercado doméstico e da capacidade de poupança interna, de uma economia de produção e de combate aos fatores internos que debilitam uma ação internacional mais qualificada (como desigualdade social, desemprego, criminalidade, fraqueza e desordem administrativa e caos fiscal), são evidências da construção de tal projeto. As políticas social, energética, urbana, fundiária e produtiva representam uma vontade política neste sentido. Paralelamente, o carisma do presidente parece haver sintetizado em sua figura franca e simples as características que o mundo admira no Brasil. Isso tem permitido que Lula desenvolva uma intensa agenda internacional como porta-voz deste projeto.

O Brasil age com otimismo e vontade política, criando constantemente fatos na área internacional. Anteriormente o país demonstrava uma baixa auto-estima, pois os governos Collor e Cardoso viam o país como atrasado em relação às nações ricas. Agora, ao contrário, o Brasil se considera protagonista de nível equivalente, com capacidade de negociação e portador de um projeto que pode, inclusive, contribuir para inserir a agenda social na globalização. Em lugar de vagos discursos contestatários e de uma obediência prática, o país tem proposto medidas e concretizado as que estão ao seu alcance. Sim, porque havia uma margem de manobra, embora limitada, que poderia mas não foi aproveitada nos anos 1990. A ênfase da era FHC foi invertida, o que implica uma inflexão significativa em termos de política externa.

Em termos práticos, o governo brasileiro suplantou a passividade do anterior e buscou alianças fora do hemisfério, como forma de ampliar seu poder de influência no âmbito internacional a partir da mencionada postura ativa e pragmática. A maior prioridade da agenda consiste na reconstrução do Mercosul e na integração sulamericana, criando um espaço para uma liderança brasileira compartilhada. Além disso, a solidariedade com a África também é central, pois associa princípios éticos e interesse nacional. A intenção de aprofundar as relações (e estabelecer uma parceria estratégica) com potências emergentes como China, Índia, Rússia e África do Sul, entre outras, ao lado do estabelecimento de uma associação estratégica com a União Européia e da valorização das organizações internacionais (especialmente a ONU), ao lado das vantagens econômicas que propicia, sinalizam a intenção de contribuir para o estabelecimento de um sistema internacional multipolar. O princípio de democratização das relações internacionais é invocado explicitamente. 
Todas essas iniciativas apontam para a tentativa de criar um equilíbrio em relação ao que permanece sendo, em função da globalização, a principal dimensão de inserção internacional: as relações com as grandes potências (especialmente os EUA) e com o capital internacional. Sem fugir a essa realidade, iniciou-se a construção de um espaço maior de barganha e de uma alternativa global, com o Brasil dando uma contribuição proporcional ao seu peso internacional. Na prática, isto significou que o Itamaraty, em lugar de concentrar-se na tentativa de cooperação com países em relação aos quais somos secundários e a mercados grandes, mas saturados, buscou os espaços não ocupados, exercitando uma diplomacia high profile. Com essas credenciais, o presidente brasileiro abriu a Assembléia Geral da ONU em Nova Iorque, evento que teve uma participação recorde de líderes em 2003.

\section{Mercosur, IIRSA e UNASUR: a integração Sul-Americana}

Uma das primeiras ações foi na Venezuela, quando o Brasil encaminhou ajuda ao país vizinho que enfrentava uma greve geral de quase dois meses mantida pela oposição contra o governo do presidente Hugo Chávez. Além disso, propôs a criação de um Grupo de Países Amigos da Venezuela, em apoio à mediação da OEA (incluiu Brasil, EUA, Chile, México, Portugal e Espanha). A proposta brasileira gerou críticas da oposição daquele país e certo desconforto por parte dos EUA. Washington foi surpreendida pela agilidade da diplomacia brasileira e procurou assumir a iniciativa como forma de minimizar a emergente liderança sul-americana do Brasil. Com o tempo, as relações do governo Bush com o Brasil se tornaram bastante cooperativas (para desalento da oposição brasileira), especialmente com o advento de novos governos de esquerda na América do Sul.

É necessário enfatizar que o Brasil possui relações intensas e amistosas com a Venezuela, independente de qual governo esteja no poder nos dois países. Acordos sobre controle de fronteira, complementação econômica, integração das redes de transporte e de energia foram estabelecidos entre Caracas e Brasília já em 1994, durante os governos Itamar Franco e Rafael Caldera (Protocolo La Guzmania). Desta forma, a ajuda brasileira não representou nenhum tipo de "solidariedade esquerdista" ou intromissão em assuntos internos de outro país, como argumentou a oposição venezuelana. Ao Brasil não interessava o caos político ou econômico em suas fronteiras (como já acontece em relação ao conflito na Colômbia), com um colapso da economia venezuelana ou uma guerra civil, que poderiam vir a ocorrer. Muito menos a quebra das regras constitucionais e a deposição de um governo eleito, o que já foi evitado com sucesso em mais de uma oportunidade pelo Mercosul em relação ao Paraguai. 
Analisando a integração sul-americana e do Mercosul definidas como a principal prioridade, oferece-se aos vizinhos uma parceria necessária para retomar o crescimento da economia, condição indispensável para que a integração deixe de ser virtual, e a possibilidade de uma ação estratégica no plano global que reverta a marginalização crescente que a região está sofrendo. Apenas a integração regional pode garantir governabilidade e desenvolvimento para toda a América do Sul e ser um instrumento indispensável nas negociações da ALCA.

Esta nova realidade permitiu reforçar a política lançada pelos países sulamericanos de desenvolver a infra-estrutura física (transporte, comunicação e energia), como forma de relançar o processo de integração. O Brasil do presidente Lula, por seu turno, dá à iniciativa uma importância estratégica, aprofundando qualitativamente a política esboçada pelo governo $\mathrm{FHC}$ em seu final. Assim, o BNDES já iniciou o financiamento de obras visando à integração física sulamericana e o assessor Marco Aurélio Garcia revelou que o governo pretendia duplicar os recursos para o programa, bem como buscar apoio do BID e outros organismos financiadores.

Já o presidente Kirchner, revelou a vontade argentina de mudar a política econômica que o país desenvolveu nos anos 1990, abandonando o neoliberalismo e buscando um modelo baseado em investimentos públicos e combate à pobreza. No plano internacional, ele manifestou a intenção de estreitar a cooperação com o Brasil, resgatar o Mercosul e contribuir ativamente para a integração sul-americana. Chama atenção que o novo governo argentino evoluiu das relaciones carnales de Menem com os EUA para uma atitude de eqüidistância, fazendo com que a Casa Branca comece a se preocupar com o surgimento de um polo autônomo BrasilArgentina.

Desta forma, o que se observa é o retorno da América do Sul ao protagonismo diplomático e ao processo de integração, com a afirmação paralela de agendas internas de desenvolvimento econômico e social. A atuação diplomática sulamericana, além disso, não se refere apenas ao plano regional, mas a uma atuação concertada de âmbito mundial. Em resumo, a associação do Peru ao Mercosul, a campanha por apoio dos países andinos à associação da Comunidade Andina de Nações ao Mercosul e o avanço concreto das medidas visando à integração da infraestrutura física dos países sul-americanos criaram um clima novo na região. Novos governos assumiram o poder com posições internacionais comuns às da diplomacia brasileira, outros alteram sensivelmente suas agendas, convergindo com a do Itamaraty. Mesmo a Colômbia, com a proposta brasileira de mediar a devolução de reféns em poder das FARC, parece começar a ver o Brasil com outros olhos, e apenas o Chile persegue seu caminho afastado de seus vizinhos. 
Integração sul-americana se realiza em três níveis: o Mercosul, a IIRSA e a CASA/UNASUL. O Mercosul representa o nível comercial e de investimentos, já relativamente encaminhado. Apesar de críticas de alguns líderes, geralmente voltadas para o público interno, o bloco tem avançado para outras áreas, como educacional, política e científico-tecnológica. Foram estabelecidas Cadeias Produtivas Regionais e um Programa de Substituição Competitiva de Importações, cujo objetivo é de fomentar as exportações dos demais membros do Mercosul para o Brasil, como forma de equilibrar o comércio. Além disso, todos os países da CAN e o Chile já são membros associados do Mercosul, apesar de que alguns deles firmaram acordos de livre comércio com os EUA.

A IIRSA, Iniciativa para a Integração Regional Sul-Americana, representa uma forma de integração funcional, voltada à construção de infra-estrutura de transportes, comunicações e energia. Ela interessa a todos os países e a atores externos como a China, a União Européia, o Japão e, mesmo, os Estados Unidos. Como frente de obras públicas ela permite gerar emprego e contornar a Lei de Responsabilidade Fiscal (ao aportar fundos internacionais não orçamentários), que limita a política de desenvolvimento interna dos Estados. A IIRSA desenvolve vários projetos, além de constituir um marco para a eventual construção dos oleodutos e gasodutos, superando a exploração da dimensão ideológica.

Por fim, a Comunidade Sul-Americana de Nações (CASA), criada em dezembro de 2004 e aprofundada em abril de $2007 \mathrm{com}$ sua transformação em União de Nações da América do Sul (UNASUL), representa um fórum para desenvolver a consciência política da integração (inclui também a Guiana e o Suriname). Ela constitui, igualmente, um locus onde ocorre um diálogo de alto nível entre os Estados membros e se resolvem muitas diferenças e divergências. Isso é particularmente útil com o advento de regimes de esquerda na região; se o Brasil, a Argentina, o Uruguai e o Chile representam modelos fortemente institucionalizados, a Venezuela, a Bolívia e o Equador ainda buscam formatar seus sistemas políticos, gerando a necessidade de um diálogo permanente. É forçoso reconhecer que a diplomacia brasileira tem tido sucesso em lidar com situações criadas pela nacionalização do gás boliviano, as crises venezuelanas e o confronto entre Colômbia e Equador em 2008, ainda que este último nos marcos da OEA. Fora da América do Sul, as ações mais relevantes têm sido a cooperação com Cuba e a Missão de Paz no Haiti. 


\section{Parcerias Estratégicas e Cooperação Sul-Sul: ideologia ou pragmatismo?}

No plano global, o Brasil tem procurado se portar à altura de um membro do BRICS (os gigantes Brasil, Rússia, Índia, China, e, depois, África do Sul, assim classificado pela consultoria Goldman-Sachs), dando conteúdo às parcerias estratégicas e fomentando a Cooperação Sul-Sul. Acusada pela oposição de iniciativa ideológica baseada na experiência do Movimento dos Países Não Alinhados nos anos 1970, as ações neste campo são focadas, pragmaticamente, em pontos comuns, sem a criação de uma frente anti-hegemônica ou anti-OCDE.

O primeiro passo foi a constituição do $\mathrm{IBAS}^{2}$ ou G-3, Fórum de Cooperação Índia, Brasil e África do Sul, uma iniciativa sul-africana, não apoiada pelo governo FHC. Os chanceleres Celso Amorim, Yashwant Sinhá e Nkosazana Dlamini-Zuma anunciaram que o G-3 buscaria promover a cooperação trilateral, a liberalização comercial recíproca e a unificação e fortalecimento de posições nos foros multilaterais. As negociações envolverão o Mercosul, a União Aduaneira da África Austral e, possivelmente, a SAARC (Área de Cooperação Regional da Ásia Meridional). Os três países manifestaram, igualmente, o desejo de se aproximar da Rússia e da China em um segundo momento, transformando-o em G-5 (se isto ocorresse, o Grupo aglutinaria quase metade da população mundial e considerável parcela da produção do planeta, podendo influir significativamente nas negociações multilaterais). A criação do G-3 constituiu uma iniciativa importante, no momento em que os países do Sul necessitam se mobilizar em defesa dos seus interesses e para alterar pontos importantes da atual agenda mundial. Trata-se, igualmente, de uma contribuição à construção de um sistema mundial multipolar, sem hegemonias e regido por organizações multilaterais.

Outras iniciativas a serem destacadas foram as visitas de Lula aos países árabes do Oriente Médio e a aproximação com a África, com oito visitas presidenciais a este continente nos primeiros seis anos de governo. Como resultado, realizaram-se regularmente Encontros de Cúpula América do Sul-Países Árabes (ASPA), tendo sido assinado acordo de cooperação Mercosul-Conselho de Cooperação do Golfo (maio de 2005) e as Reuniões de Cúpula África-América do Sul (ASA).

As visitas de Lula foram importantes não apenas para as relações do Brasil com a África (11 visitas, 29 países, 17 novas Embaixadas), mas, sobretudo, para o estabelecimento de uma associação institucionalizada entre o Mercosul e a SACU (União Aduaneira da África Austral), a área de integração nucleada pela África do

\footnotetext{
2 Ver: http://www.forumibsa.org, acesso em maio de 2009.
} 
Sul na parte meridional do continente. Na África, o Brasil se tornou um novo ator de peso, ao lado da China e da Índia. As relações com os paises Árabes e do Oriente Médio foram incrementadas não apenas em comercio, mas igualmente em termos diplomáticos, pois o Brasil foi convidado a mediar a crise do Irã e da Palestina.

Tratou-se de aproveitar as brechas existentes no sistema internacional, aprofundadas após o 11 de setembro de 2001, ocupando espaços que foram extremamente importantes para ampliar as exportações de bens e serviços e para expandir a ação de empresas brasileiras e a influência internacional do país. A solidariedade ativa também é importante, com os projetos na área social e da saúde, além da atuação conjunta nos organismos internacionais, através das coalizões de geometria variável, como o G-20 Comercial. O presidente Lula logrou a façanha de superar FHC em número de viagens ao exterior, embora numa geografia e com um estilo pessoal diferentes. Lula passou a ser visto como uma novidade, falando português, com seu estilo espontâneo, e as campanhas contra a pobreza, que tanto desdém desperta em nossa classe média, granjeou-lhe enorme prestígio mundial.

As relações com a China finalmente atingiram o patamar de uma Parceria Estratégica e a cooperação com a Rússia e, no plano bilateral, com a Índia e a África do Sul evoluem nessa direção. Não apenas no plano do comércio e dos investimentos há avanços, mas também nas ações concertadas no plano multilateral (apesar de algumas divergências pontuais) e nos projetos conjuntos em ciência e tecnologia de ponta (aero-espacial, energia atômica, militar). A campanha pela obtenção de um assento permanente no Conselho de Segurança da ONU, por sua vez, se apóia nessas alianças, no up grade da posição internacional do país e na proposta de associá-la a uma reforma que confiram maior poder à Assembléia Geral e ao Conselho Econômico e Social (ECOSOC).

\section{Um novo enfoque para as relações Norte-Sul}

No campo político-diplomático, o governo Lula iniciou quando estava para eclodir a invasão americana ao Iraque. A posição brasileira foi firme, recusando respaldar qualquer ação sem que os inspetores da ONU concluíssem seu trabalho e que a Organização desse seu aval. A atitude foi extremamente bem acolhida pelos integrantes do chamado Eixo da Paz (França, Alemanha e Rússia), ressaltando a nova autonomia da diplomacia do Itamaraty. Participar do Fórum Social Mundial em Porto Alegre e, dias depois, do Fórum Econômico Mundial em Davos, Suíça, aumentou o prestígio do presidente Lula, ainda que produzindo desencanto por parte da esquerda. Da mesma forma, a condenação ao terrorismo foi acompanhada da 
rejeição da agenda da Guerra ao Terrorismo, e o tempo somente veio dar sentido à postura brasileira.

Um exemplo adicional do contínuo poder de mobilização da diplomacia do governo brasileiro foi a estruturação do G-20, que atuou de maneira eficiente na reunião da OMC em Cancun. Cordial, mas contestadora, a diplomacia brasileira estabeleceu sua rede com os países em desenvolvimento afetados pelo protecionismo e pelos subsídios agrícolas do Primeiro Mundo. O chamado G-22 surpreendeu os países ricos e fez a insatisfação do Sul ser ouvida, em meio ao encerramento espetacular do encontro. Assim, a tendência é a de que uma constelação sulamericana e de outras importantes potências (não exatamente um "bloco") venha a contribuir para moderar a postura norte-americana nas relações internacionais, simultaneamente auxiliando na construção de um mundo multipolar regido pelo sistema das Nações Unidas.

Somados, todos estes acontecimentos tiveram impactos nas relações de Brasil e EUA e, certamente, nas negociações da ALCA. Atualmente as negociações da ALCA se encontram bloqueadas, apesar de que se afirmava que ela era "inevitável". As manifestações do presidente Bush de que não estaria disposto a retirar os gigantescos subsídios agrícolas à agricultura americana e o protecionismo a produtos como o aço, bem como a medidas unilaterais destinadas a defender a economia americana, representam uma resposta à base de poder do presidente, pouco propícia a grandes acordos multilaterais de liberalização comercial. Subsídios, barreiras nãotarifárias, patentes, compras governamentais e outros itens seriam encaminhados para a $\mathrm{OMC}$, e Bush teria uma sigla para exibir ao eleitorado americano. Na reunião da ALCA, realizada em Port of Spain, os EUA deixaram claras estas posições. Ocorre que para os países do Mercosul, e o Brasil em particular, estes temas eram fundamentais. E, da mesma forma, há questões na ALCA que não lhes interessam, o que dificulta o projeto.

Igualmente, o processo foi dificultado por outras questões estruturais de hegemonia norte-americana, como o custo de suas decisões referentes à Guerra do Iraque e do Afeganistão. Com isso, a Casa Branca, frente às crescentes dificuldades nas negociações da ALCA, necessitaria contar com o apoio brasileiro, pois sem ele a ALCA não será implementada, dado que os EUA já têm acesso às economias dos demais países, que são de dimensões menores que a brasileira. Ironicamente, colocar as negociações em bases corretas fez com que a iniciativa de congelar a ALCA viesse da própria parte americana, neutralizando prováveis reações por parte da oposição brasileira. As negociações da ALCA estão suspensas. 
O governo Lula, por sua vez, começou a negociar mais firmemente, visando defender os interesses econômicos brasileiros. Como global trader, o país deseja manter suas relações com várias áreas do mundo, priorizando o Mercosul e a integração sul-americana. Depois de reverter as expectativas americanas de que o governo teria políticas esquerdistas, Lula passou a ser "admirado" em Washington. Mas é preciso observar que a diplomacia do Brasil, ao contrariar alguns desígnios da potência hegemônica e ressaltar sua autonomia, criou uma razoável margem de manobra. Assim, chamou atenção para suas reivindicações sócio-econômicas e de obras de infra-estrutura com os vizinhos.

Dessa forma, a diplomacia se apresenta como o campo mais bem sucedido do atual governo, com o país recuperando uma ação de grande intensidade e alcance planetário, digna da quinta nação mais populosa e extensa e da décima economia do mundo. Este protagonismo junto ao Terceiro Mundo e a diversificação dos vínculos com o Primeiro Mundo dão também ao país certo cacife para intensificar a campanha pela obtenção de um assento permanente no Conselho de Segurança da ONU reformado, como membro permanente. Ironicamente, hoje o Brasil tem melhor diálogo com Washington e uma diplomacia mais respeitada, com capacidade de negociação. A crise econômica e o desgaste diplomático-militar dos EUA, no contexto do término dos dois mandatos do presidente Bush constituem pontos interessantes para reflexão.

\section{Balanço e perspectivas}

O presidente foi reeleito, em segundo turno, com 58 milhões de votos (61\%) e o segundo mandato tem, como foi prometido, dado maior atenção ao projeto de desenvolvimento e ao plano social. Novas jazidas de petróleo fizeram o país se tornar auto-suficiente e projetos como o etanol e o enriquecimento de urânio apontam para avanços, mas a frente política segue frágil, com enorme polarização, inclusive contra a política externa. O governo procura manter um baixo perfil e, nesse sentido, muitas vezes não reage de forma adequada. A razão da política externa ser a frente mais ousada do governo Lula reside no fato dela estar sendo dirigida pelo Itamaraty (e apoiada por parte dele), que recuperou seu espaço, e conta com o apoio de segmentos dentro do Estado, preocupados com a questão nacional, como o BNDES e as Forças Armadas.

O campo da ciência e tecnologia é decisivo, e os países que não focarem seu desenvolvimento nos setores aero-espacial, nuclear, de defesa, informática e biotecnologia, ficarão em segundo plano. É necessário, igualmente, promover a 
inclusão social (gerando um novo paradigma, que compatibilize trabalho e revolução tecno-científica), equilíbrio ambiental e governabilidade democrática. Mas esta tarefa não pode ser realizada no plano exclusivamente doméstico, e sim global, incluindo a questão social, ambiental e democrática na agenda da globalização, e para isso é necessário uma política externa à altura dos desafios.

Durante a última década o Brasil elecou sua posição política e econômica no cenário mundial, e esta tendência foi mantida mesmo com a crise financeira internacional, que atinge os países da OCDE desde 2008. No mesmo sentido, o nivel de vida dos brasileiros vem sendo melhorado significativamente. Por isto, a candidata indicada por Lula à presidencia, Dilma Rousseff, cujo governo iniciou em Janeiro de 2011, a despeito de alguns ajustes de estilo, está mantendo os aspectos principais do desenvolvimento e da diplomacia do ex-presidente. A participação do Brasil no G-20 Financeiro e no BRICS representam apenas alguns dos arranjos para lidar com o crescente desequilíbrio entre a ordem econômica (crescentemente multipolar) e a ordem politico-militar (que permanence dominada pela superpotência remanescente, os EUA).

\section{REFERÊNCIAS}

ALTEMANI, Henrique, e LESSA, Antônio Carlos (Orgs.). Relações Internacionais do Brasil. São Paulo: Saraiva, 2006. 2 vols.

BATISTA Jr, Paulo Nogueira. O Brasil e a economia internacional. Recuperação e defesa da autonomia nacional. Rio de janeiro: Campus/Elsevier, 2005.

CERVO, Amado. Relações Internacionais do Brasil. Um balanço da era Cardoso. Revista Brasileira de Política Internacional. Número 45: 2002, p. 5-35.

CEPIK, Marco (Org.). América do Sul: economia \& política da integração regional.Porto Alegre: UFRGS, 2008.

FARIA, Luiz Augusto Estrella. A chave do tamanho: desenvolvimento econômico e perspectivas do Mercosul. Porto Alegre: UFRGS, 2004.

GUIMARÃES, Samuel Pinheiro. Desafios do Brasil na era dos gigantes. Rio de Janeiro: Contraponto, 2006. 
MINISTÉRIO das Relações Exteriores. Repertório da Política Externa: posições do Brasil. Brasília: FUNAG, 2007.

. Obras de integração física na América do Sul. Brasília: MRE, 2007.

SALLUM Jr, Brasilio. “A condição periférica:o Brasil nos quadros do capitalismo mundial (1945-1990)". In MOTA, Carlos Guilherme (Org.). Viagem incompleta: a experiência brasileira (1500-2000)". São Paulo: SENAC, 2000.

SENNES, Ricardo. As mudanças da política externa brasileira nos anos 80: uma potência média recém industrializada. Porto Alegre: Ed. da UFRGS, 2003.

SILVA, Luiz Inácio Lula da, AMORIM, Celso, e GUIMARÃES, Samuel Pinheiro. $A$ política externa do Brasil. Brasília: FUNAG, 2003.

VISENTINI, Paulo, and SILVA, André Reis. "Brazil and the Economic, Political and Environmental Multilateralism" in Revista Brasileira de Política Internacional. Special Edition, Brasília, 2010.

VIZENTINI. Paulo. Relações Internacionais do Brasil: de Vargas à Lula. São Paulo: Editora Fundação Perseu Abramo, 2008. A política externa do regime militar brasileiro.

VIZENTINI, Paulo, \& WIESEBRON, Marianne (Eds.). Free trade for the Américas? FTAA and the US push for integration. London/ New York: Zed Books, 2004. 


\section{RESUMO}

Durante o Governo Lula (2003-2010) o Brasil viveu significativas melhorias sociais e econômicas, mas especialmente desenvolveu uma diplomacia "ativa e afirmativa" de envergadura global, que lhe garantiu autonomia e prestígio internacional. Sob a coordenação do Brasil a integração sul-americana avançou. O pais estabeleceu parcerias estratégicas com a China, a Rússia, a índia e a África do Sul, o que, somado ao avanço da cooperação Sul-Sul ganhou, alterou o rumo das negociações multilaterais globais. Ao lograr eleger sua sucessora, o legado da diplomacia de Lula deve se aprofundar, contribuindo para a reforma da ordem mundial.

\section{PALAVRAS-CHAVE}

Governo Lula; política externa brasileira; diplomacia do Brasil. 


\section{A VIRADA RUSSA PARA A AMÉRICA LATINA}

Yuri Paniev ${ }^{l}$

Café aromático, bananas maduras, belas orquídeas, samba ardente e novelas - esse é o padrão russo de associações que surge quando a América Latina é mencionada. E embora o pico da cooperação entre a União Soviética e o "continente flamejante" fora abandonado nos anos 1970, a Rússia moderna o está recuperando. Como resultado, a América Latina tem se tornado, talvez, o mais espetacular componente das atividades internacionais de Moscou nos últimos anos.

Bilhões de dólares em contratos, projetos conjuntos em várias esferas e tecnologias de última geração são o que aproxima Rússia e América Latina atualmente. A Rússia mantém relações diplomáticas com todos os 33 países da região, e com 18 deles possui acordos baseados em novos princípios cooperativos nada do tipo existiu anteriormente. Alguns analistas inclusive preveem uma nova "era de ouro" para a cooperação Rússia - América Latina.

De acordo com Vladimir Davydov, diretor do Instituto da América Latina e membro correspondente da Academia Russa de Ciência, a intensidade sem precedentes do diálogo Rússia-América Latina deve-se ao fato de que os líderes russos perceberam a importância estratégica do continente. "Por anos a iniciativa partiu da América Latina, que despontavam com suas exportações, visando aumentar o nível de contatos políticos. Moscou estava reagindo... sem verdadeira inspiração", salientou Davydov. "Felizmente, a situação mudou drasticamente". ${ }^{2}$

Nos dias de hoje, a Rússia tem o conceito de sua política externa, aprovada em 12 de julho de 2008, que reflete diretamente o desejo de Moscou de construir a cooperação política e econômica com os países da América Latina e do Caribe, expandi-la com eles em organizações internacionais, promover exportações de produtos industriais de alta tecnologia na região, efetuando projetos em energia e

\footnotetext{
1 Um dos grandes especialistas em América Latina, Academia Russa de Ciência (RAS). (austral@ufrgs.br)

2 "Gazeta", M., 21-23.11.2008
} 
infraestrutura, incluindo aquelas que fazem parte dos planos desenvolvidos pelas associações de integração regional. ${ }^{3}$

Falando sobre fatores que conduziram à aproximação da Rússia com a América Latina, o Ministro das Relações Exteriores da Rússia, Sergey Lavrov destacou a similaridade de pontos de vista acerca dos principais problemas internacionais. "Com os parceiros da América Latina nós daremos um passo a frente como aliados naturais em assuntos tais como a necessidade de assegurar a supremacia do direito internacional, o reforço de mecanismos multilaterais para a solução de problemas internacionais, o papel central das Nações Unidas e a procura de respostas coletivas para desafios do mundo moderno" - salientou Lavrov. "Nós também temos uma abordagem comum quanto à reforma da arquitetura do mundo financeiro". ${ }^{4}$

Além disso, a abordagem mútua ocorre devido a uma série de características similares no desenvolvimento social e político do passado recente e no presente dos dois. Esse importante fator deve ser levado em consideração quando se analisa todo o complexo das relações bilaterais.

Durante o período de 2000-2011 os presidentes da Rússia visitaram a região latino-americana seis vezes; os ministros de relações exteriores, mais de dez vezes. Por sua vez, só em 2009 nosso país foi visitado pelos presidentes de Bolívia, Brasil, Venezuela, Cuba, Chile e Equador. Encontros ao nível de primeiro ministros e chefes dos departamentos de diplomacia ocorrem regularmente, bem como contatos com líderes latino-americanos no decurso de diferentes fóruns internacionais. Durante esse período, mais de 200 documentos conjuntos abrangendo vários aspectos de cooperação foram assinados. Michelle Bachelet, ex-presidente do Chile, que visitou Moscou duas vezes, até sugeriu a ideia de fazer do Chile um tipo de plataforma para reforçar a cooperação russa com a América Latina. ${ }^{5}$

Uma menção especial deve ser feita ao Brasil, com o qual a Rússia tem desenvolvido parcerias no âmbito da coalizão dos BRICS, que também compreende China, Índia e África do Sul. Esses são os famosos gigantes de segundo nível, que contribuem com 25\% do PIB mundial, 30\% do território terrestre e $45 \%$ da população mundial. ${ }^{6}$ Esses países mantêm uma estreita cooperação em foros internacionais, incluindo o recém-estabelecido G-20, que está firmemente

\footnotetext{
${ }^{3}$ O Conceito de Política Externa da Federação Russa - http://www.mid.ru/ns-osndoc.nsf/

4 “Latin America”, M., 2009, № 2

5 "President", M., 16-22.09.2010

6 "International Life", M., 2011, № 6
} 
suplantando o antes onipotente G-8. Há muito bom senso na definição dos BRICS feita por Vadim Lukov, negociador russo e enviado especial. Ele denominou o BRICS como a "aliança dos reformadores", tendo em mente seu foco comum na reorganização das instituições internacionais e principalmente das financeiras. ${ }^{7}$

É importante que atualmente a Rússia esteja desenvolvendo relações construtivas não só com os países da América Latina de forma individual. Ela também estabeleceu contatos regulares com associações políticas regionais, incluindo o "Grupo do Rio", a Organização dos Estados Americanos (OEA) e com o sistema latino americano de integração. Essas estruturas possuem observadores russos, que produzem recomendações quanto aos métodos e meios de intensificar essa cooperação.

A política russa na América Latina tem se tornado, de longe, mais intensa. Entre desenvolvimentos novos e importantes, há o crescimento da atividade empresarial privada, que considera a região não somente como fonte de bens importados, sobretudo alimentares, mas também como um mercado considerável para os produtos industriais russos, incluindo alta-tecnologia, e como promissora área para investimentos. Afinal, a América Latina constitui um mercado bastante amplo e solvente, totalizando meio bilhão de consumidores. Um bom exemplo de tais desenvolvimentos pode ser a criação da quarta geração de redes e serviços de comunicações móveis na Nicarágua pela companhia russa Yota, que em termos de qualidade deixou para trás os serviços de outros concorrentes.

O interesse empresarial na América Latina está sendo impulsionado por desenvolvimentos positivos na economia de uma série de países, pela aceleração do crescimento do PIB e do volume de comércio externo, bem como pelo papel proeminente daqueles países na OMC e em outras organizações internacionais influentes. A maioria dos países latino-americanos tem sido capazes de suportar o choque de crise econômica global de 2008-2009, adotando efetivos programas anticrise e, desta maneira, confirmando o aumento de sua estabilidade econômica e financeira. É igualmente importante que os empresários latino-americanos têm acessado ativamente nosso mercado, estabelecendo clientes e relações de parceria na Rússia. Como resultado, o "sotaque latino-americano" no comércio exterior russo e em suas relações econômicas exteriores está se tornando cada vez mais distinto.

A experiência acumulada de cooperação econômica prova que as economias da Rússia e da maioria dos países latino-americanos são complementares: os latino-

\footnotetext{
7 “Independent Newspaper", M., 5.03.2012
} 
americanos requerem exportações russas e vice-versa. Isso, sem dúvida, é uma situação macroeconômica positiva que tem se desenvolvido naturalmente. Contudo, enquanto são implementadas, essas favoráveis pré-condições ainda enfrentam muitas dificuldades. Não admira que quase todos os documentos sobre resultados de visitas de qualquer nível incluam a disposição de que o atual nível dos laços econômicos russo-latino-americanos ainda está atrás de seu potencial.

Tais demandas tem toda razão de existir. Primeiramente, os negócios russos na maioria dos países latino-americanos são ainda pouco conhecidos e a imagem empresarial das empresas russas geralmente deixa a desejar. $O$ canal mais importante das propostas de propaganda comercial e dos projetos de investimento das principais companhias russas continua sendo as visitas de alto nível à região. Esse foi o caso, por exemplo, durante a viagem de Vladimir Putin a México, Brasil e Chile em 2004 e de Dmitry Medvev para Peru, Brasil, Venezuela e Cuba em 2008. Em segundo lugar, os empresários russos enfrentam uma árdua competição do mundo ocidental, e, mais recentemente, das companhias chinesas. Ambos recorrem a seus respectivos governos em caso de dificuldades e utilizam todo tipo de recurso para estabelecer relações com autoridades locais e com os meios de comunicação a fim de garantir um tratamento mais favorável. Em terceiro lugar, a estrutura das exportações russas para a América Latina tendem a se tornar mais primitivas que antes. Já há algum tempo as bases dos produtos russos para a região tem sido formada por bens atribuídos a grupos de produtos semi-acabados incluindo fertilizantes, aço laminado e produtos em papelão. Em certas categorias de produtos de alta tecnologia, Brasil e México deixaram a Rússia bem para trás. É difícil de acreditar, mas há 20 anos a situação era completamente diferente: de 25,3 mil carros importados pelo Brasil, 23,1 mil eram fabricados pela empresa russa VAZ. ${ }^{8}$

Finalmente, o sistema de pagamentos mútuos, investimentos e de cooperação tecnológica e científica continuam vulneráveis mesmo que a indústria de alta tecnologia possa se tornar o motor de uma pareceria bem-sucedida. Nesse aspecto, tanto Moscou quanto as capitais latino-americanas depositam suas esperanças na tão conhecida aliança tecnológica. No caso do Brasil, por exemplo, tal aliança é mais provável de se revelar na indústria aeroespacial. Tanto mais porque desde 2006 as partes assinaram um acordo de proteção mútua de tecnologia na área de exploração espacial e sobre uso do espaço para propósitos pacíficos. Os brasileiros estão interessados em usar nossa tecnologia para produzir combustível líquido para seus veículos de lançamento. É menos perigoso que o combustível seco e permitirá evitar

8 "Moscow News", M., 22-28.12.2006 
uma tragédia como ocorreu na área brasileira de Alcântara em 2003, quando 21 pessoas morreram.

Comércio russo com países latino-americanos (em milhões de dólares)

\begin{tabular}{|c|c|c|c|c|}
\hline País & 1992 & 2000 & 2008 & 2010 \\
\hline Região Inteira & 1330,3 & 5669,7 & 15935,0 & 12260,0 \\
\hline Argentina & 150,5 & 122,9 & 1975,9 & 1124,1 \\
\hline Brasil & 146,8 & 645,9 & 6711,2 & 5874,5 \\
\hline Chile & 22,4 & 19,5 & 364,7 & 356,6 \\
\hline Cuba & 832,1 & 385,2 & 265,1 & 276,0 \\
\hline Equador & 14,9 & 185,2 & 935,7 & 974,1 \\
\hline México & 19,0 & 156,7 & 1230,9 & 768,8 \\
\hline Peru & 19,2 & 35,7 & 327,6 & 328,0 \\
\hline Venezuela & 22,1 & 67,7 & 957,8 & 165,3 \\
\hline
\end{tabular}

Fonte: Serviço Federal de Alfândega da Federação Russa. Estatísticas da alfândega/comércio exterior para os respectivos anos.

Como se pode observar na tabela, o Brasil ocupa a primeira posição no volume de comércio russo com os países da América Latina. Se no período da Guerra Fria a motivação dos líderes soviéticos para desenvolver relações com a América Latina teve uma tonalidade ideológica, e o principal negócio e parceiro econômico na região, que nunca fora distinguido por elevados indicadores econômicos, foi Cuba. 
Hoje, substituindo a ideologia por uma abordagem programática, o principal parceiro é o Brasil, corretamente considerado a "superpotência regional".

O ex-presidente brasileiro Fernando Henrique Cardoso costumava enfatizar que o Brasil é uma espécie de "Rússia tropical" e que esses dois países têm muito em comum. A similaridade não se aplica só a parâmetros como o tamanho do território e a população, mas também aos indicadores macroeconômicos. Rússia e Brasil ocupam posições similares da divisão internacional de trabalho, atuando como importadores de tecnologias e de capitais avançados. Há também uma coincidência de objetivos na política externa, que incluem a formação de um novo sistema policêntrico internacional dependendo do processo de integração no nível regional.

O dia 22 de Julho de 2000 certamente se tornará um marco na história das relações econômicas Rússia-Brasil. Primeiramente, porque naquele dia uma reunião muito aguardada da alta comissão russa e brasileira para a cooperação ocorreu em Moscou (na época nós tínhamos comissões de tal nível somente com Ucrânia, Itália, França e Estados Unidos). Em segundo lugar, documentos importantes foram assinados e têm regulado as relações entre esses dois países até o presente. Em terceiro lugar, na capital russa os representantes dos círculos empresariais de ambos os países se encontraram em um seminário de negócios de uma escala sem precedentes. Tudo isso deu razão para o presidente da Câmara da Indústria, Comércio e Turismo Brasil-Rússia Gilberto Ramos dizer: "Depois de um longo período de namoro nossos países finalmente formalizaram relações e celebraram um casamento". 9

Como resultado, em dez anos o volume de negócios aumentou em mais de seis vezes, e, de acordo com o ministro de desenvolvimento, indústria e comércio exterior brasileiro, ultrapassou os 6 bilhões de dólares em 2010. No entanto, a porcentagem russa no volume de negócios do gigante da América Latina ainda corresponde somente a 2,2\%. ${ }^{10}$ Apesar do enorme potencial no comércio, a variedade de produtos ainda é bastante limitada. Atualmente as entregas russas para o mercado brasileiro são limitadas a matérias-primas e bens com baixos níveis de processamento: fertilizantes e níquel.

No que diz respeito às exportações brasileiras para a Rússia, sua estrutura é bastante diferente das exportações para países desenvolvidos, que se tornaram os maiores consumidores da produção industrial brasileira. A modernização no Brasil

\footnotetext{
9 “Time MN", M., 23.06.2000

${ }^{10}$ Ministério do Desenvolvimento, Indústria e Comercio Exterior. Intercâmbio comercial brasileiro com a Rússia. Brasilia. Doc. RT_102, 10/01/2011
} 
ainda está acontecendo muito mais rapidamente que na Rússia. O país alcançou a liderança em diversas áreas, sobretudo na produção de combustíveis alternativos. Hoje o Brasil é o terceiro maior exportador de aeronaves no mundo, e um sério concorrente no campo da genética e de tecnologias de perfuração em águas profundas. O Brasil é capaz de desenvolver os seus campos petrolíferos na plataforma continental, e em poucos anos se tornará o maior exportador de hidrocarbonetos.

Ao mesmo tempo, para a Rússia, o Brasil continua como um tradicional fornecedor de café, açúcar, soja, frango e carne congelados, que correspondem por mais de $90 \%$ do total de importações. Além disso, os fabricantes brasileiros estão enfrentando um problema com a grande falsificação de café instantâneo na Rússia, e com periódicas proibições nas importações de carne bovina e de porco devido a razões veterinárias, dentre outras. Em um país onde de acordo com as estatísticas há uma vaca para cada um dos 190 milhões de habitantes, o tema da carne se tornou um sério problema político, danificando as relações Rússia-Brasil. O Brasil é um dos principais fornecedores de carne para a Rússia, e, de acordo com o Instituto de Agromercado, em 2010 foi responsável por 35\% das importações de carne de porco da Rússia (215 mil toneladas), 45\% de carne bovina (269 mil toneladas) e 19\% de carne de ave (121 mil toneladas). ${ }^{11}$

Visando dar um novo impulso para a cooperação, Moscou e Brasília estão em processo para desenvolver mecanismos de pagamento baseados nas moedas nacionais. Em um futuro próximo, Rússia e Brasil planejam abandonar o dólar norte-americano como meio universal de pagamento das transações entre esses países. O Brasil tem sido bem-sucedido em adotar tal abordagem com a Argentina: ambos os países trocaram para suas respectivas moedas como um modo de pagamento no comércio bilateral no âmbito do Mercosul.

O ano de 2010 marcou o $125^{\circ}$ aniversário das relações diplomáticas entre Rússia e Argentina. Portanto, a visita do presidente Dmitry Medvedev em abril de 2010 - a primeira viagem de um oficial de primeiro nível russo para esse país - teve um significado simbólico, como foi salientado na declaração conjunta. Mais importante, contudo, foi o "conteúdo material" da visita. As negociações com a presidente Cristina Fernandez de Kirchner e os documentos assinados posteriormente em Buenos Aires registraram uma ampla variedade de relações

\footnotetext{
${ }^{11}$ On meat imports prohibition from 89 Brazilian producers to RF starting from June 15, 2011. http://www.agronews.ru/newsshow.php?NId=66514
} 
existentes e identificaram as áreas mais promissoras para a futura cooperação. Em particular, o conjunto de acordos estabelece ${ }^{12}$ :

- cooperação na área de uso pacífico da energia atômica, incluindo possível cooperação com a Rosatrom relativa à construção da usina nuclear Atucha III;

- $\quad$ acordo entre a Agência Espacial Federal (Roskosmos) e a Comissão Nacional de Atividades Espaciais (CONAE) para cooperação no uso e no desenvolvimento do Sistema Global de Navegação por Satélite - GLONASS;

- ação conjunta entre a Saturn Scientific and Production Association e o Governo da Província de Buenos Aires para modernização da Central Térmica de 9 de Julho;

- participação da Russian Railways JSC na modernização da rede ferroviária argentina;

- participação do All-Russia Research Institute of Geology Overseas no campo de estudos geológicos de hidrocarbonetos e minerais na Argentina;

- intenção de cooperação no domínio florestal.

Além disso, um memorando de cooperação entre organizações comerciais dos dois países foi assinado, e o presidente Medvedev participou da reunião de negócios entre representantes de importantes companhias e bancos russos e argentinos, fazendo o discurso de abertura. "Nós chegamos perto da implementação prática dos projetos nos campos de alta tecnologia, incluindo infraestrutura nuclear, espacial, energética e de transporte. Aqui ao nosso lado vocês têm os dirigentes das principais companhias russas, públicas e privadas. Nós já obtivemos histórias de cooperação bem-sucedidas no campo energético. Hoje, um quarto de toda energia na Argentina é gerada por turbinas russas". 13

Os círculos diplomáticos também prestaram atenção nas palavras de Medvedev, sublinhando que "a Rússia retornou à América Latina", fazendo-o "vigorosamente", e está agora desenvolvendo ativamente as relações com os parceiros latino-americanos. "É evidente que a posição da Rússia em relação à

\footnotetext{
12 Documents signed as a result of Russia-Argentina talks, April 15, 2010. http://news.kremlin.ru/ref_notes/522/print

13 “Página 12", Buenos Aires, 15.04.2010
} 
América Latina mudou", disse Medvedev. "Nós acreditamos que aqui vivem nossos amigos e pessoas próximas a nós, e gostaríamos de cooperar com eles mais intensamente". ${ }^{14}$

A Rússia ofereceu suas tecnologias à Argentina não somente no setor energético, onde já existe experiência de cooperação, mas também em algumas áreas como o transporte ferroviário (quase metade das ferrovias do país estão inoperantes), a pesquisa da Antártica, onde os quebra-gelos e os helicópteros russos são exigidos, a exploração espacial e o uso pacífico da energia nuclear. De acordo com Medvedev, a chegada de "Rosatom" no mercado argentino implicará em bilhões de dólares de investimento para a construção das respectivas unidades de geração de energia, bem como para o desenvolvimento de infraestrutura. Tais projetos criam o tão conhecido efeito multiplicador, que torna possível desenvolver sub-setores relacionados, novas unidades de produção e empregos.

O fato da cooperação com a Rússia ajudar a reduzir o desemprego - um problema doloroso para a América Latina - foi muito ilustrativo no caso da Venezuela. A chegada de corporações russas privadas e estatais como a GazpromNeft, Rosneft, LUKoil, Surgutneftegas e TNK-BP contribuíram para a criação de milhares de novos empregos no país. Grandes companhias energéticas russas, que juntamente com a companhia estatal venezuelana Petroleos de Venezuela (PDVSA) formaram o Consórcio Nacional de Petróleo (PNC), estão se preparando para extrair o "ouro preto" na área rica em petróleo Junin-6 do delta de Orinoco (petróleo bruto estimado em 53 bilhões de barris). $\mathrm{O}$ desenvolvimento desse rico campo levará cerca de 40 anos e necessitará de investimentos de 20 bilhões de dólares. ${ }^{15}$ Só para ter acesso ao campo de petróleo Carabobo-2, como foi aprovado em outubro de 2011, a Rosneft despendirá 1 bilhão de dólares. ${ }^{16}$

O aspecto fundamental da cooperação Rússia-Venezuela é o fato de que seu desenvolvimento ocorre sob o ideologicamente chamado "Projeto Bolivariano" liderado pelo presidente Cháves, que visa construir o socialismo do século XXI em um só país. Portanto, o motor venezuelano colocará sua cooperação com Moscou no contexto do discurso anti-estadunidense, o que às vezes tensiona o governo russo e, na prática, certamente cria um novo ambiente geopolítico no Caribe.

\footnotetext{
14 "Russian Newspaper", M., 16.04.2010

15 "Vedomosti", M., 2.02.2010

16 "Commersant", M., 8.10.2011
} 
Durante os anos de seu governo, Chávez visitou a Rússia nove vezes. Enquanto acolhia o líder venezuelano em 2001, Putin disse: "A cooperação com a Venezuela é um elemento fundamental das relações russas com a América Latina". 17 Naquele momento o diálogo político entre os dois países começara a ganhar forma junto às principais áreas de cooperação econômica: petróleo e gás, químicos e petroquímicos, desenvolvimento conjunto de recursos naturais e cooperação militar. Com o passar dos anos, ambos os países conquistaram resultados tangíveis em todas essas áreas, fazendo da Venezuela a parceira privilegiada da Rússia na região.

A Venezuela tornou-se o segundo maior comprador dos equipamentos militares russos, logo após a Índia. De acordo com o Centro para Análise de Comércio de Armas Global, o custo das armas e equipamentos militares russos adquiridos por Caracas é estimado em 4.4 bilhões de dólares. Isso inclui 24 jatos de combate Su$30 \mathrm{MK} 2 \mathrm{~V}, 100$ mil metralhadoras AK-103, mais de 40 helicópteros multifuncionais Mi-17V-5, 10 helicópteros de ataque Mi-35M2, 3 helicópteros de transporte pesado Mi-26T2, 5 mil rifles de precisão SVD, 12 sistemas de mísseis de defesa antiaérea TorM1, armas antiaéreas ZU-23-2 e um lote de mísseis antiaéreos portáveis Igla-S. De acordo com a agência de notícias ANV, em agosto de 2011 a Venezuela recebeu outro lote de armas antiaéreas ZU-23, morteiros portáveis e veículos blindados. De acordo com o Ministro de Defesa venezuelano Carlos Mata Figueroa "nós precisamos desses armamentos para a defesa do nosso país". 18

Julgando pelo resultado das negociações, das quais o Vice-Primeiro-Ministro russo Igor Sechin participou em outubro de 2011 em Caracas, a Venezuela receberá outros 4 bilhões de dólares de empréstimo da Rússia para modernizar as suas forças armadas. De acordo com Chávez "serão 2 bilhões no próximo ano e 2 bilhões em 2013". “Nós podemos fazer isso hoje porque nós somos livres - disse o líder venezuelano". "Nós não poderíamos ter feito isso antes porque éramos dominados pelos ianques, pelo o Banco Mundial e por toda uma estrutura imperial econômica e financeira". 19

Liberdade do Ocidente Caracas considera transferir suas reservas financeiras dos Estados Unidos e da Europa para o seu principal banco central e para países como Rússia, Brasil e China. Supõe-se que esses fundos servirão de garantia para empréstimos de que a Venezuela precisa. De acordo com várias estimativas, mais de 6 bilhões de dólares poderiam fluir da Venezuela para a Rússia, mais da metade do que é mantido na Suíça, enquanto que o restante é mantido nos bancos dos Estados

\footnotetext{
17 "Bilivarian Project and Prospects for Russia-Venezuela Partnership", M., 2005, c. 40.

18 "Independent Newspaper", M., 19.08.2011

${ }^{19}$ El Universal", Caracas, 7.10.2011
} 
Unidos, da Inglaterra e da França. Segundo o Banco Central da Venezuela, suas reservas estrangeiras chegam a 29,9 bilhões de dólares, dos quais 18,3 estão em ouro. ${ }^{20} \mathrm{Na}$ Venezuela eles estão convencidos de que no futuro próximo essas reservas irão aumentar significativamente, já que a liderança do país decidiu nacionalizar a exploração de ouro e minério.

Falando sobre os parceiros-chave da Rússia na América Latina, não se pode esquecer o antes maior aliado e amigo mais próximo - Cuba. No período póssoviético da cooperação Rússia-Cuba, que por 30 anos desempenhou o papel de suporte estratégico político e econômico para a União Soviética na América Latina (durante 1960-1990 em Cuba a União Soviética construiu mais de 1.000 instalações, 100 delas grandes empreendimentos industriais), houve uma queda drástica em todas as esferas.

Em 1991 Moscou informou Havana que iria recolher todas as 7 mil pessoas de sua equipe técnica em um mês, congelando todos os projetos de construção, e recusando todo suporte na esfera civil e militar. A evacuação ocorreu frente a surpresos e desorientados cubanos, da mesma maneira que especialistas estadunidenses fugiram do país antes da chegada do exército rebelde de Che Guevara em Havana. Como resultado, todas as atividades foram pausadas nos projetos industriais mais importantes, incluindo a planta metalúrgica Jose Martí, a planta de níquel Las Camariocas e a Havana TPP, nos quais enormes gastos foram feitos. Só para construir a usina nuclear de Jaragua, a União Soviética gastou cerca de 1,2 bilhão de dólares. ${ }^{21}$

A última grande "rendição" russa em Cuba ocorreu em 2003, quando o centro de vigilância rádio-eletrônico em Londres, que permitia aos especialistas russos interceptarem chamadas de telefone e emails em todo os Estado Unidos, foram desligados. De fato, poderia se dizer que a Rússia rejeitou Cuba e deixou-os sem apoio. Mas os cubanos, apesar das expectativas daqueles que se opunham ao regime de Fidel Castro, sobreviveram sem desistir dos princípios ideológicos e de sua persistência na construção do socialismo.

A nova situação geopolítica mundial e as mudanças políticas da América Latina levaram Moscou a procurar meios de restaurar as relações Rússia-Cuba. A primeira tentativa de reviver a cooperação foi feita em setembro de 2006 durante a visita do então primeiro-ministro russo Mikhail Fradkov, que resolveu o problema da dívida cubana com a Rússia, uma soma de 166 milhões de dólares, além de fixar

20 "The Financial Times", London, 17.08.2011

21 "Latin America in Current World Politics", M., 2009. c. 524. 
crédito para a compra de equipamentos russos e peças de reposição na soma de 355 milhões de dólares. ${ }^{22}$

A visita presidencial de Medvedev a Havana em novembro de 2008 marcou o início de um novo estágio nas relações bilaterais entre os países. Recordando que em tempos de União Soviética as relações com Cuba eram "bastante poderosas", Medvedev disse: "Agora é hora de restaurá-las". ${ }^{23}$

Em 2009 o então Presidente do Conselho de Estado e do Conselho de Ministros de Cuba Raúl Castro veio à Moscou. Durante a visita, um memorando sobre os princípios de cooperação foi assinado, estruturando a base para a revitalização da cooperação bilateral. Os acordos incluíram ações conjuntas para criar uma ordem mundial justa e policêntrica, além da implementação de um número de projetos importantes, principalmente na área de energia, transporte, aviação civil, biofarmácia e alta tecnologia.

Parece que a longa pausa das relações Rússia-Cuba chegou ao fim. Mas também é óbvio que o novo nível de cooperação exigirá esforços constantes de ambos os lados. Além do mais, nossas companhias terão que retomar o que antes foi descuidosamente abandonado pela Rússia sem se incomodar em contar as perdas. $O$ petróleo explorado por especialistas soviéticos na plataforma, na qual recursos consideráveis foram investidos, agora é produzido por canadenses, franceses e malaios. Como resultado, a GazpromNeft, por exemplo, não teve outra opção a não ser assinar um acordo com a companhia malaia Petronas, segundo o qual receberá 30 por cento da exploração e da produção conjunta offshore no setor cubano do Golfo do México. As reservas comprovadas de petróleo nessa área são pequenas: 260 milhões de toneladas. No entanto, o total das reservas é muito maior: a Cubapetroleo estima que superem os 2,7 bilhões de toneladas; segundo a U.S. Geological Survey, há 1,2 bilhão de toneladas de petróleo e 21 trilhões de metros cúbicos de gás. ${ }^{24}$

Uma situação inusitada foi construída nas relações entre Rússia e Equador: uma rota direta de containers ligando Guayaquil e São Petesburgo foi aberta. Existem projetos de investimentos em curso na agricultura e na indústria alimentícia. Os produtores de banana do Equador têm a oportunidade de desenvolver a produção usando investimentos provindos da Rússia. Investimentos também são feitos para desenvolver as áreas de processamento e de embalagem.

\footnotetext{
22 "Vremya Novostei", M., 29.09.2006.

23 "Russian Newspaper", M., 27.11.2008.

24 "Expert”, M., 2010, № 46.
} 
Também deve ser destacado que nos países latino-americanos os estudantes mantiveram o interesse em estudar na Rússia, apesar de não repetir a escala típica da era soviética. Atualmente, somente centenas de estudantes estão interessados em vir e estudar diferentes especialidades na Rússia. Existem certas dificuldades associadas à cobertura dos gastos da viagem e à garantia de uma bolsa escolar decente. No entanto, esses complexos problemas podem ser resolvidos. Os formandos de universidades russas criaram suas próprias associações em vários países da América Latina, construindo uma considerável contribuição para o desenvolvimento da cooperação bilateral e identificando abordagens para novas áreas.

A nova política russa na América Latina estimulou certa polarização de opiniões e comentários na região e além dela. Muitos observadores ocidentais acreditam que a revitalização da política de Moscou na região é um curso geopolítico que visa recuperar o estatuto de grande potência direcionado contra os Estados Unidos, enquanto a venda de armas para Venezuela está contribuindo para uma escalada da corrida armamentista na região. Para outros, a atividade russa na América Latina é somente uma resposta equilibrada para a expansão do Ocidente à Comunidade dos Estados Independentes (CIS).

De fato, a promoção da cooperação com a América Latina pela Rússia é guiada por considerações geopolíticas. Meu país, no entanto, não é o único quando se olha para formas de expandir presença no mundo utilizando rápido crescimento e oportunidades econômicas. Isso também se aplica à cooperação militar não somente com a Venezuela, mas também com Argentina, Bolívia, Brasil, Peru e Chile, cujos acordos foram assinados durante o período 2004-2009. Como grande produtor e exportador de armamentos, a Rússia, naturalmente, está procurando por novos mercados para os seus produtos, incluindo aqueles na América Latina. Todas as alegações de que isso está contribuindo para uma corrida armamentista não se sustentam. Aqui vai um fato eloquente: o líder regional em gastos militares é a Colômbia (4\% do PIB), enquanto a Venezuela gasta não mais que $1.3 \%$ do seu PIB. 25 No entanto, os armamentos da Colômbia não vêm da Rússia, mas dos Estados Unidos e da França, ambos, aliás, estão se tornando líderes em exportações para o mercado latino-americano nesse setor. Até o momento, a Rússia só conseguiu chegar ao terceiro lugar.

25 Nueva Sociedad", Buenos Aires, 2010, N 226, p. 9. 
Contudo, o raciocínio político russo pode ser totalmente diferente. Países latino-americanos têm aumentado constantemente seu potencial econômico, e seu papel nos assuntos mundiais são aperfeiçoados continuamente. Os exemplos não estão longe: México e Chile juntaram-se à Organização para a Cooperação Econômica e Desenvolvimento (OECD), um grupo da maioria das nações desenvolvidas, enquanto a Argentina, o Brasil e o México fazem parte do G-20. De fato nós estamos testemunhando a emergência de outro centro no mundo multipolar, algo impossível de ignorar. Além do mais, a Rússia e os países da América Latina clamam por um maior papel na economia global e na regulação financeira. Somente esforços conjuntos e interações construtivas com outros estados ascendentes ajudarão a atingir esses objetivos. Descrevendo a importância geopolítica da América Latina, o presidente Medvedev disse: “Nós estamos apenas no começo de uma relação forte, de grande escala e de mútuo benefício com os parceiros da América Latina. Não há motivo para sermos escrupulosos e medrosos acerca da competição. Nós devemos entrar logo na briga". ${ }^{26}$ Por "briga" ele obviamente quis dizer competição - os Estados Unidos estão tradicionalmente presentes na região, assim como a Europa Ocidental, e recentemente a China. A emergência da Rússia na América Latina é somente uma nova realidade geopolítica que evidencia seus interesses globais.

Recebido em 14 de março de 2012. Aprovado em 21 de março de 2012.

*Artigo traduzido por Gabriela Perin e revisado por Raul Cavedon Nunes

26 "Independent Newspaper", M., 1.12.2008. 


\section{RESUMO}

O artigo descreve as atuais relações da Rússia com os principais países latinoamericanos: Brasil, Argentina, Venezuela e Cuba no âmbito comercial, econômico e militar. $O$ autor chama atenção para as verdadeiras intenções da política russa de aproximação com o continente: seriam as parcerias geopolíticas aliadas na recuperação do status russo de potência direcionada contra os Estados Unidos ou simplesmente uma jogada inteligente frente à emergência de novas potências no mundo multipolar?

\section{PALAVRAS-GHAVE}

Rússia. América Latina; Parcerias estratégicas; Mundo multipolar. 


\title{
REORDENANDO AS RELAÇÕES INTERNACIONAIS: O FÓRUM DE COOPERAÇÃO CHINA-ÁFRICA
}

\author{
Mamoudou Gazibo e Olivier Mbabia ${ }^{I}$
}

A Emergência da China se tornou evidente durante os anos 2000, momento caracterizado pelo unilateralismo da superpotência americana sob a administração de George Bush Jr.. Essas circunstâncias explicam grande parte das estratégias adotadas pela China para evitar o isolamento e defender seus interesses ${ }^{2}$. É o caso, particularmente, do multilateralismo, anteriormente visto com desconfiança, mas que o país acabou por adotar, chegando a torná-lo um elemento essencial da "grande estratégia diplomática", tendo uma vocação a assegurar, especialmente em nível regional $^{3}$.

A China, assim, tem se envolvido em uma série de parcerias privilegiadas com grupos regionais como a União Europeia, a Organização de Cooperação de Xangai, a Asean e diversas outras organizações mundiais e regionais ${ }^{4}$. É nesse mesmo contexto que deve-se colocar o lançamento do Fórum de Cooperação China-África (FOCAC) em 2000 .

Pode-se entender o FOCAC como um grupo multilateral imperfeito, sabendo que as relações bilaterais estão no centro da interação entre a China e os países africanos, tanto dentro, quanto fora dessa instituição. Nessas condições, a necessidade Chinesa de balancear o unilateralismo americano é o suficiente para explicar adequadamente as razões de ser do FOCAC? Trata-se de uma organização no modelo de outras organizações, como a Commonwealth ou a Organização Internacional da Francofonia? Os países africanos são verdadeiros atores nessa

\footnotetext{
${ }^{1}$ Mamoudou Gazibo é professor do Departamento de Ciência Política da Universidade de Montreal, Canadá. Olivier Mbabia é pesquisador associado à Cátedra de Estudos Chineses Contemporâneos do Instituto Católico de Paris, França. (austral@ufrgs.br)

2 Melvin Gurtov e Peter Van Ness (dir.), Confronting the Bush Doctrine. Critical Views from South East Asia, Londres, Routledge, 2005.

3 Avery Goldstein, “The Diplonmatic Face of China's Grand Strategy: A Rising Power's Emerging Choice", The China Quarterly, vol. 168, 2001, p. 842-844.

${ }^{4}$ Guogang Wu e Helen Lansdowne, China Turns to Multilateralism: Foreign Policy and Regional Security, Londres, Routledge, 2008
} 
instituição, ou eles gravitam em torno da China que, esta sim, define as normas e princípios e se beneficia sozinha?

Nesse artigo, temos dois objetivos. Primeiro, mostrar como o FOCAC participa da estratégia chinesa de construção de alianças, permitindo-lhe resistir melhor ao unilateralismo americano e aos riscos de ser barrado por seus rivais ocidentais em geral ${ }^{5}$. Em seguida, mostrar que, como instituição, o FOCAC é um verdadeiro lugar de socialização, isto é, de construção e difusão de normas, de práticas e de comportamentos para e entre os participantes e que, longe de ser um simples instrumento manipulado pela China, ele é tanto uma estrutura quanto uma ferramenta com impactos compartilhados.

Em um primeiro momento, esboçaremos brevemente o arcabouço teórico e conceitual construtivista que sustenta nosso argumento, recorrendo a conceitos de soft balancing e de socialização. Na seção seguinte, recordaremos o contexto de criação do FOCAC destacando características institucionais e seu impacto nas relações sino-africanas. Não se trata de avaliar a adequação deste dispositivo institucional em relação aos objetivos declarados, mas de examinar a capacidade deste grupo de influenciar alguns aspectos da política internacional ao forjar uma identidade comum e privilegiando os interesses e as práticas comuns. Vemos, por fim, que apesar das características paradoxais da instituição que continua fortemente desequilibrada em favor da China, ela oferece aos seus participantes uma plataforma que permite, inclusive aos atores africanos, seguidamente considerados, de maneira equivocada, vítimas, dispor de recursos materiais e simbólicos que os quadros institucionais de cooperação tradicionais não proporcionam.

\section{Soft Balancing e socialização: o FOCAC em uma perspectiva construtivista}

Muito tem se falado na hegemonia do poder americano desde o fim da Era bipolar. Como resposta de sobre como os outros Estados reagiriam a este fato, certos observadores sugeriram a adoção de "estratégias de oposição", enquanto outros falavam em "estratégias de acomodação"6. Nesse caso, o FOCAC pode ser considerado como um grupo multilateral que visa não somente contrabalançar a

\footnotetext{
5 Mamoudou Gazibo e Roromme Chantal, Un nouvel ordre mondial made in China ?, Montréal, Presses de l'Université de Montréal, 2011.

6 Ver Stephen M. Walt, Taming American Power: The Global Response to US primacy, New York, Norton, 2005.
} 
primazia americana, mas também construir uma identidade e interesses compartilhados entre os seus membros.

O multilateralismo pode, grosso modo, ser entendido como uma ação coletiva institucionalizada por um grupo determinado de Estados independentes. No entanto, é mais "útil" insistir na dimensão institucional do multilateralismo, que remete a toda ação entre três, ou mais, Estados " com base nos princípios gerais de conduta " (não discriminação, indivisibilidade e reciprocidade $)^{7}$. Soma-se à isso uma dimensão normativa que faz dessa forma institucional uma estrutura capaz de criar e promover normas comuns ${ }^{8}$.

Contrariamente à abordagem institucionalista neoliberal que defende a importância da influencia exercida pelas instituições sobre o comportamento dos Estados, os construtivistas afirmam que as instituições participam da constituição das identidades e dos interesses. Nesse sentido, os entendimentos e representações que os agentes sociais tem do mundo são "amplamente compartilhadas" 9 . Na verdade, os padrões cognitivos que orientam as práticas de um agente são intersubjetivas e produtoras de normas, de regras e de instituições. Para os construtivistas, essas normas e regras são forças constitutivas ao invés de simplesmente reguladoras, o que significa que elas possibilitam determinados comportamentos ao intervir na constituição das identidades e dos interesses dos atores $^{10}$. As instituições são, então, entidades fundamentalmente cognitivas que não existem para além das ideias dos atores.

Além disso, o conceito de Soft Balancing permite explicar como a China baseia-se, em sua estratégia internacional, em fóruns como o FOCAC, o Fórum de Cooperação China-América Latina e o Fórum de Cooperação Sino-Árabe. Por Soft Balancing, entende-se geralmente qualquer ação tomada por um Estado fraco para ganhar influência frente a um outro Estado mais forte. Outros limitam a noção aos esforços coordenados entre países menos influentes e ações em resposta à ameaças de segurança por parte da potência hegemônica ${ }^{11}$. Segundo T.V. Paul, a noção remete a uma "construção de uma coalizão não-defensiva para neutralizar uma potência

7 John Ruggie, "Multilateralism: the Anatomy of an Institutional Form”, in J. G. Ruggie (dir.) Multilateralism Matters: the Theory and Praxis of an International Form, New York, Columbia University Press, 1993, p. 11.

${ }^{8}$ De acordo com Marie-Claude Smouts, uma das funções do multilateralismo é de construir um "senso comum" . Marie-Claude Smouts, Les Organisations internationales, 1995, Paris, Armand Colin, p. 29.

9 Alex Macleod, Evelyne Dufault et F. Guillaume Dufour (dir.), Relations internationales. Théories et concepts, Montréal, Athéna éditions, 200 (2e édition), p. 32-34

10 Ibid.

${ }^{11}$ Para o debate sobre Soft Balancing, ver em particular os 4 artigos sobre o conceito em International Security, Vol. $30, \mathbf{n}^{\circ} 1$, Summer 2005. 
consideravelmente ameaçadora"12. Esse autor indica que longe de apresentar um desafio militar, o Soft Balancing é um instrumento através do qual as potências médias são capazes de desafiar a superpotência em termos de legitimidade de suas políticas ${ }^{13}$. O Soft Balancing, que frequentemente toma forma no uso da diplomacia, das instituições internacionais, do direito internacional, das pressões econômicas, não permite, em geral, frear ou conter a superpotência, mas torna sua tarefa mais complexa e o custo político ou financeiro por ela suportado maior. O FOCAC pode, a partir deste ponto de vista, ser entendido como uma organização multilateral não só reguladora, mas também produtora de normas de interesse.

\section{A institucionalização do Fórum de Cooperação China-África e seus efeitos de estruturação das relações sino-africanas}

O Fórum de Cooperação Sino-Africano ${ }^{14}$ é, oficialmente, uma plataforma de consultas e diálogos coletivos entre a China e os "países africanos amigos". Apresenta-se como uma estrutura de colaboração igualitária entre os países que sofreram os danos do colonialismo e que querem se inserir, na continuidade do espírito de Bandung, a base do movimento dos Não-Alinhados. Nessa linha, o Fórum se reúne com o objetivo de "combater juntos a hegemonia e a dominação ocidentais" e estabelecer "uma nova ordem mundial"15.

Três aspectos são dignos de nota: a institucionalização gradual do FOCAC, o efeito estruturante da instituição que ele se tornou com as relações econômicas sinoafricanas e a emergência através dele, de questões políticas comuns.

\section{O processo de institucionalização do FOCAC}

O FOCAC foi lançado durante a presidência de Jiang Zemin, por ocasião da primeira conferência ministerial realizada em outubro de 2000, em Pequim. $O$ evento reuniu 44 países africanos, organizações internacionais e regionais, bem como

\footnotetext{
12 T.V. Paul, "Introduction: The Enduring Axioms of Balance of Power Theory and Their Contemporary

Relevance," in Balance of Power. Theory and Practice in the 21st Century, ed. T.V. Paul et al. (dir.), Stanford, Stanford University Press, 2004, p. 14.

${ }^{13}$ Ibid., p. 59.

${ }^{14}$ Estas informações estão disponíveis no site do FOCAC na internet (http://www.focac.org/)

15 "Le nouvel ordre chinois en Afrique", La Libre Belgique, 26 avril 2006.
} 
representantes do setor privado. Essa primeira iniciativa contou com a presença, além do Secretário-Geral da Organização da Unidade Africana (OUA), dos chefes de Estado da Argélia, do Togo, da Tanzânia e da Zâmbia.

A coordenação política do Fórum é realizada pela Conferência de Ministros que acontece trienalmente, alternadamente na China e em um país africano. Foi a primeira conferência que aprovou, em outubro de 2000, o texto fundador intitulado "Programa de Cooperação Sino-africana para o Desenvolvimento Econômico e Social", bem como os três Planos de Ação seguintes (Addis Abeba, Pequim e Sharmel Sheikh).

Depois de Pequim, em 2000, a Segunda Conferência Ministerial foi realizada em Adis Abeba, Etiópia, em dezembro de 2003. Além dos promeiros-ministros Wen Jiabao da República Popular da China (RPC) e de Meles Zenawi da Etiópia, participaram seis chefes de Estado, três vice-presidentes, dois primeiros-ministros, um presidente de senado, o presidente da Comissão da União Africana (UA, Alpha Omar Konaré) e o representante do Secretário-Geral das Nações Unidas.

A partir dessa cúpula, vemos uma verdadeira institucionalização do Fórum. Na terceira Conferência Ministerial, o FOCAC se transformou em uma cúpula de alto nível. O presidente chinês recebeu assim 48 chefes de Estado e de governo africanos em Pequim, em novembro de 2006. No mês de novembro de 2009, elites chinesas e africanas se encontraram no Egito para a quarta Conferência Ministerial do FOCAC, enquanto a quinta conferência acontecerá durante o outono de 2012, na China.

O FOCAC é dotado de um mecanismo de acompanhamento que é resultado das consultas ministeriais entre chineses e africanos realizada na Zâmbia, em 2001. Depois de entrar em vigor em abril de 2002, o mecanismo de acompanhamento é feito de encontros entre o Comitê de Acompanhamento chinês e funcionários africanos. O Comitê de Acompanhamento chinês do Fórum, cujo secretariado está localizado no Departamento Africano do Ministério chinês de Relações Exteriores, é presidido pelos Vice-Ministros de Relações Exteriores e de Comércio.

As conferências ministeriais são uma oportunidade de anunciar as decisões tomadas durante as discussões. Esses anúncios assumem a forma de Declarações e de Planos de Ação ${ }^{16}$, que lembram os princípios da parceria sino-africana, retomam as realizações do FOCAC e dão uma orientação de natureza programática à cooperação entre as partes nos três anos que se seguem depois de cada Fórum.

${ }^{16}$ Para ter acesso aos documentos, dirigir-se ao site do FOCAC, <http:/www.focac.org/>. 
Principais medidas anunciadas pelos Planos de Ação, 2003, 2006 e 2009

\begin{tabular}{|c|c|}
\hline $\begin{array}{l}\text { Plano de } \\
\text { Ação de Adis } \\
\text { Abeba (2004- } \\
2006)\end{array}$ & $\begin{array}{l}\text { - Reforçar a cooperação em matéria de exploração de recursos } \\
\text { humanos e oferecer treinamentos multissetoriais à } 10000 \text { africanos; } \\
\text { - Acordar uma tarifa zero para a importação de certos produtos } \\
\text { provenientes dos países africanos menos avançados; } \\
\text { - Expandir a cooperação turística através da concessão do status de } \\
\text { "destino aprovado" à Etiópia, ao Quenia, à Zambia, às Ilhas } \\
\text { Maurício, Seychelles, ao Zimbabue e à Tunísia; } \\
\text { - Multiplicar o intercambio entre os povos através da organização } \\
\text { em Pequim, em 2004, do Festival das Juventudes Chinesa e } \\
\text { Africana. }\end{array}$ \\
\hline $\begin{array}{ll}\text { Plano de } & \text { Ação } \\
\text { Pequim } & \\
(2007-2009) & \end{array}$ & $\begin{array}{l}\text { - Duplicar de } 2006 \text { à } 2009 \text { a ajuda à África; } \\
\text { - Fornecer US } \$ 5 \text { bilhões de créditos preferenciais; } \\
\text { - Estabelecer um fundo de desenvolvimento de } 5 \text { bilhões de dólares } \\
\text { para encorajar os investimentos chineses na África; } \\
\text { - Anular as dívidas dos países pesadamente endividados e menos } \\
\text { desenvolvidos; } \\
\text { - Remover as tarifas de } 440 \text { produtos dos países africanos menos } \\
\text { desenvolvidos; } \\
\text { - Criar três à cinco zonas de livre-comércio e de cooperação } \\
\text { econômica; } \\
\text { - Completar, ao longo dos três anos seguintes, a formação de } 15000 \\
\text { profissionais africanos, duplicar o número de bolsas de estudos } \\
\text { universitários concedidas aos estudantes africanos; } \\
\text { - Enviar } 100 \text { agrônomos e abrir } 10 \text { centros pilotos de técnicas } \\
\text { agrícolas; } \\
\text { - Construir } 300 \text { hospitais e conceder US } \$ 30 \text { milhões para o combate } \\
\text { à malária; } \\
\text { - Enviar } 300 \text { jovens voluntários, construir } 300 \text { escolas. }\end{array}$ \\
\hline
\end{tabular}




\begin{tabular}{|c|c|}
\hline $\begin{array}{lr}\text { Plano de } & \text { dẽão de } \\
\text { Sharm } & \text { el- } \\
\text { Sheikh } & (2010- \\
2012) & \end{array}$ & $\begin{array}{l}\text { - Estabelecer uma parceria sino-africana de luta contra as } \\
\text { mudanças climáticas através da realização de } 100 \text { projetos de } \\
\text { energia limpa (solar, biogás, pequenas centrais hidrelétricas); } \\
\text { - Implementar } 100 \text { projetos pilotos de pesquisa científica conjunta e } \\
\text { receber } 100 \text { pós-doutorandos na China; } \\
\text { - Fornecer US\$ } 10 \text { bilhões em empréstimos preferenciais, incluindo } \\
1 \text { bilhão para ajudar pequenas e médias empresas africanas; } \\
\text { - Dar tratamento tarifário zero à } 95 \% \text { dos produtos provenientes } \\
\text { dos países menos desenvolvidos, dos quais } 60 \% \text { antes do fim de } \\
\text { 2010; } \\
\text { - Elevar para } 20 \text { o número de centros agrícolas piloto, enviar } 50 \\
\text { missões técnicas agrícolas e formar } 2000 \text { técnicos agrícolas } \\
\text { africanos; } \\
\text { - Fornecer material para os centros anti-malária e formar } 3000 \\
\text { enfermeiros e médicos para a África; } \\
\text { - Construir } 50 \text { escolas, formar } 1500 \text { diretores de escola e professores } \\
\text { e elevar para } 5500 \text { o número de bolsas do governo chinês. }\end{array}$ \\
\hline
\end{tabular}

Fonte : compilação dos autores a partir dos Planos de Ação de Adis Abeba 2003, de Pequim 2006 e de Sharm el-Sheikh 2009.

\section{O FOCAC e a reestruturação das relações econômicas sino-africanas}

O FOCAC reestruturou as relações entre a China e a África sob dois ângulos principais. Por um lado, ele produz um efeito de coordenação das intervenções chinesas na África e, por outro, ele literalmente aumenta o nível da cooperação entre a África e a China.

O FOCAC permite, em primeiro lugar, que a China coordene melhor a ação de seus diferentes atores na África. $\mathrm{Na}$ verdade, o crescimento dos interesses estratégicos chineses na África desde a segunda metade dos anos 90 colocou em pauta a questão crucial da "orquestração" dos assuntos africanos. Três principais atores desempenham um papel nas relações com o continente: os governos central e provinciais, as empresas multinacionais e seus representantes e, por fim, os atores individuais, sejam eles empresários privados ou trabalhadores. Esses atores com racionalidades diversas (imagem e reputação internacionais para o governo nacional, 
prioridade local para as províncias e regiões chinesas, aventurismo ou empreendedorismo dos empresários chineses) representam um verdadeiro desafio à prática da política no local. Nessa lógica, o FOCAC aparece, antes de tudo, como uma resposta organizacional à multiplicação de interesses e aos múltiplos atores que influenciam na definição e execução da política chinesa na África.

O FOCAC permite, também, uma progressão, tanto quantitativa, quanto qualitativa, das interações entre chineses e africanos, sendo possível falar sobre certos aspectos - e no caso de certos países africanos - de reorientação de suas relações internacionais.

É claro, não se pode atribuir a expansão do intercâmbio econômico e comercial, a renovação diplomática e o rápido estabelecimento de comunidades chinesas na África e africanas na China simplesmente às decisões tomadas no FOCAC. É preciso reconhecer, entretanto, que essa instituição atua como um catalisador desses desenvolvimentos. Na verdade, medidas como a eliminação de barreiras tarifárias, o envio de voluntários, a simplificação dos procedimentos consulares ou a cencessão de bolsas agora são decididas no FOCAC (ver tabela acima). Como exemplo, conjuntamente ao FOCAC II, foi realizada a primeira Conferência de Empresários Chineses e Africanos, na qual foram celebrados 21 acordos, em um total de 1 bilhão de dólares ${ }^{17}$.

No plano comercial, as medidas tomadas em Adis Abeba, em 2003, e em Pequim, em 2006, favoreceram o crescimento do volume de comercio entre a China e a África, que passou de 10 bilhões de dólares em 2000, para 124 bilhões de dólares em $2010^{18}$. Além disso, seis zonas de cooperação econômica estão sendo construídas e cerca de 1600 empresas chinesas se instalaram na África, onde os investimentos diretos chineses atingiram 7,8 bilhões de dólares.

Além da revitalização dos interesses econômicos e comerciais, o FOCAC também oferece uma plataforma de promoção de interações humanas. Pode-se notar um aprofundamento da cooperação cultural e social entre a China e a África (aumento do número de bolsas de estudos do governo chinês para estudantes africanos, cuja presença em instituições acadêmicas chinesas é cada vez mais importante). Como exemplo, quatro das oito medidas anunciadas na $4^{\text {a }}$ conferência do FOCAC são diretamente associadas à educação e à formação de profissionais. Além disso, os intercâmbios culturais se intensificam através do envio de jovens

17 " 1 ère conférence des Entrepreneurs chinois et africains", disponível em: <http://www.focac.org/fra/ltda/dejbzjhy /INFO2/t163432.htm>.

18 "Chine-Afrique : un immense potentiel de coopération économique”, Xinhua, 27 janvier 2012 
voluntários chineses à África, bem como pelo recebimento de artistas africanos em manifestações culturais na China. Ainda, desde a abertura do primeiro Instituto Confucius em Nairobi, no Quênia, em 2005, vários outros surgiram ${ }^{19}$.

Existe um debate sobre a durabilidade do engajamento chinês na África. Alguns, que o consideram ligado a interesses específicos como os hidrocarbonetos ou o isolamento de Taiwan, acreditam que ele será reduzido à medida que esses objetivos forem sendo atingidos. No entanto, tudo leva a crer que a trajetória tomada pelas relações sino-africanas desde o estabelecimento do FOCAC deve ser mantida no longo-prazo. Na verdade, a função de pivô realizada pelo Fórum nas relações entre a China e a África parece expandir-se gradualmente. Mecanismo diplomático único dedicado à promoção do diálogo entre a China e a África, o FOCAC "facilita também o desenvolvimento de uma agenda política e econômica comum, necessária para o estabelecimento de uma cooperação política e econômica Sul-Sul mutuamente benéfica. Instrumento de reforço da cooperação sino-africana, o FOCAC é igualmente uma estrutura que permite desenvolver uma agenda comum em um sistema internacional mais globalizado. As deliberações do FOCAC aproximaram os líderes africanos e chineses e esculpiram uma visão compartilhada em matéria de coordenação política, de maior interação comercial e de prosperidade comum"20.

Além disso, essa institucionalização é vista no fato de que além das relações bilaterais com os países da África ou multilaterais com o conjunto do continente, a China desenvolve também uma cooperação com as organizações regionais ou subregionais africanas. Ela tem uma cooperação estreita com a Nova Parceria para o Desenvolvimento Africano (NEPAD), assim como apoia a União Africana (UA) para que ela desempenhe um papel ativo nos assuntos regionais e internacionais. A construção da nova sede da UA em Adis Abeba constitui, indubitavelmente, uma das manifestações mais simbólicas da atenção crescente que os dirigentes chineses dedicam aos organismos regionais africanos. Na verdade, a China lançou um diálogo estratégico anual com a Comissão da União Africana, em 2008 ${ }^{21}$, bem como um fórum econômico e comercial com a Comunidade Econômica dos Estados da África Ocidental (CEDEAO). Anteriormente, a China havia nomeado representantes junto à UA, junto à Comunidade de Desenvolvimento da África Austral (SADC), junto à CEDEAO e junto ao Mercado Comum da África Oriental e Austral (COMESA).

\footnotetext{
${ }^{19}$ Confucius Institute Online, <http://www.confuciusinstitute.net/>

20 Garth Shelton et Farhana Paruk, The Forum on China-Africa Cooperation: A Strategic Opportunity, Johannesburg, Institute for Security Studies, 2008, p. 2.

${ }^{21}$ Ministério de Relações Exteriores da RPC, “China-AU Strategic Dialogue Officially Launched" 27 de novembro de 2008.
} 
Além disso, Pequim realizou modestas contribuições financeiras às missões da União Africana no Sudão (Darfur) $)^{22}$ e na Somália.

Essa estruturação cada vez mais densa das relações sino-africanas tem como consequência o crescimento dos interesses comuns às duas partes em diversos aspectos.

Aspectos econômicos do FOCAC nos projetos e interesses políticos comuns

Desde a sua criação, o FOCAC foi apresentado como uma instituição voltada a facilitar a cooperação dos membros em matéria de relações internacionais. Como precisa a Declaração de Pequim, de 2000, as partes se comprometem a reforçar o papel das Nações Unidas e de promover ativamente as reformas da ONU e das instituições financeiras internacionais, de maneira à obter uma representação adequada dos países em desenvolvimento, particularmente os africanos. A partir dessa perspectiva, a instituição aparece com um instrumento voltado a contrabalançar o unilateralismo através da criação de relações entre Estados, que rompem diametralmente com o sistema característico da Guerra Fria ${ }^{23}$.

Com as transformações recentes no cenário internacional (afirmação de novas potências emergentes e dificuldades econômicas no ocidente), a República Popular da China ambiciona publicamente contribuir para uma redefinição do sistema internacional. Seus objetivos parecem convergir em torno da promoção de uma cooperação Sul-Sul ${ }^{24}$, que levaria à um mundo constituído de diversos polos de poder. A partir dessa perspectiva, o efetivo africano na Organização das Nações Unidas (quase um terço dos Estados membros) e, por consequência, seus votos potenciais na Assembleia Geral, fazem do continente um ator no qual a China pode confiar. A África, por sua vez, poderia igualmente buscar apoio de Pequim em questões internacionais dentro da $\mathrm{ONU}$.

\footnotetext{
${ }^{22}$ He Wenping, "China's unceasing efforts to resolve Darfur issue”, China Daily, 3 de janeiro de 2008.

23 Zheng Bijian, "China's Peaceful Rise to Great Power Status", Foreign Affairs, vol. 84, $\mathbf{n}^{\circ} 5$, September/October 2005, p. 18-24.

24 Nesse contexto, a cooperação Sul-Sul pode ser definida como a promoção das interações econômicas entre países em desenvolvimento a nível bilateral, regional e global, a fim de alcançar a autosuficiência coletiva. Considerada nesse contexto, a cooperação é um processo que implica um crescimento do comércio e do investimento juntamente à transferência de tecnologias e uma cooperação política e econômica adequada através de uma sincronização das políticas. Ver Chris Alden, "Southern Africa in South-South Relations", in Philip Nel, Patrick McGowan (eds.), Power, Wealth and Global Order, Rondebosch, University of Cape Town Press, 1999.
} 
Oficialmente, um dos objetivos da diplomacia chinesa é a construção de laços estreitos no Sul, se opondo à uma dominação unilateral global. O reagrupamento multilateral representado pelo FOCAC permite, dessa forma, com a renovação da retórica da luta contra o colonialismo e pela emancipação dos povos, forjar, ou legitimar, uma frente comum contra toda tentativa de hegemonia global. Em Adis Abeba, em 2003, o premiê Wen Jiabao lembrava que "a hegemonia continua seu caminho"25, daí a necessidade de fazer oposição com os esforços unidos. Na verdade, "Devido à sua percepção de sua própria posição no sistema internacional, a China tem construído uma política externa consistente, focada em prevenir ou limitar o desenvolvimento de "hegemonia", enquanto busca, ao mesmo tempo, criar um espaço para que ela mesmo, assim como sua economia, continue crescendo. ${ }^{26}$.

Para além de reforçar os mecanismos de cooperação bilateral e regional com os Estados africanos, a China privilegia igualmente o reforço da cooperação e a consulta entre a China e a África nos fóruns multilaterais como a Organização Mundial do Comércio e a Conferência das Nações Unidas sobre o Comércio e o Desenvolvimento (CNUCED), como forma de coordenar seus pontos de vista e aumentar o poder de negociação dos países em desenvolvimento, como um grupo, na definição do sistema econômico e comercial multilateral e de suas respectivas regras. Dessa forma, Pequim argumenta que a China e a África juntas poderiam contribuir para o estabelecimento de uma nova ordem econômica justa e razoável ${ }^{27}$.

Certamente, como diz a pesquisadora chinesa He Wenping, a China, em sua progressão rumo ao status de polo que faz diferença no sistema internacional "também terá necessidade de apoio político e moral da África" ${ }^{28}$. Mas a retórica em favor de um mundo mais justo encontra uma resposta positiva na África, porque corresponde aos objetivos africanos.

Na verdade, a China está comprometida, em parceria com a África, através do FOCAC, em contribuir para a melhoria da posição dos países em desenvolvimento na arena internacional. Daí sua reivindicação pela democratização das relações internacionais e por mais igualdade nas instâncias decisórias, tanto políticas quanto econômicas, especialmente a OMC e a ONU. Observadora assídua dos mecanismos institucionais e do funcionamento da ONU, a China esta, hoje em dia, pronta a

25 Discurso de Wen Jiabao na cerimônia de abertura do FOCAC II, Addis Abeba, 15 décembre 2003.

${ }^{26}$ Ian Taylor, China and Africa: Engagement and Compromise, London, Routledge, 2006, p. 1.

27 Garth Shelton, “China, Africa and South Africa Advancing South-South Co-operation” in Atilio Boron, Gladys Lechini, Politics and Social Movements in an Hegemonic World: Lessons from Africa, Asia and Latin America, Buenos Aires, Clacso, 2005, p. 347-383.

${ }^{28}$ He Wenping, “The Balancing Act of China's Africa Policy”, China Security, Vol. 3, n 3, 2007, p. $23-40$. 
pressionar por uma reforma institucional da organização, para promover a entrada de países africanos. Na perspectiva da reforma do Conselho de Segurança da ONU, por exemplo, a China apoia abertamente a admissão de países africanos. $\mathrm{O}$ conjunto de países africanos se reúne em torno de uma proposição, apoiada por Pequim, que demanda dois assentos permanentes com direito à veto e dois assentos não permanentes suplementares para a África. A esse respeito, no lançamento do FOCAC III, a Declaração de Pequim - documento adotado em conjunto - é bastante clara: "Nós demandamos uma reforma da ONU e de outras instituições internacionais multilaterais com o objetivo de que elas sirvam melhor todos os membros da comunidade internacional. Essa reforma deve objetivar o aumento do papel da ONU, um maior aproveitamento das funções da sua Assembleia Geral e a dar uma maior atenção à questão do desenvolvimento. É preciso dar prioridade ao aumento da representação e da plena participação dos países africanos no Conselho de Segurança da ONU e em outras instituições das Nações Unidas ${ }^{29}$.

Podemos ver que o FOCAC se tornou uma verdadeira instituição. Ele fornece um novo contexto às relações sino-africanas que têm progredido consideravelmente nos planos político e econômico, baseadas em interesses comuns. Esta intensificação das relações não é apenas física. Ela também leva, cada vez mais, a uma mudança de visão dos atores que nela estão engajados.

\section{FOCAC, lugar de socialização e promoção de normas}

Convém analisar a função de socialização do FOCAC, na acepção da abordagem construtivista segundo a qual uma instituição produz modos de fazer e de pensar sua internalização em um grupo. Ela produz um habitus, isto é, um conjunto de disposições profundamente incorporadas, que norteiam as práticas, os gostos, as escolhas e as aspirações dos atores que, por sua vez, também interpretam e influenciam as normas que lhes guiam ${ }^{30}$.

\footnotetext{
29 Declaração de Pequim, Cúpula do Fórum de Cooperação Sino-Africana. Pequim, Novembro de 2006.

30 O habitus aqui tem o sentido dado por Pierre Bourdieu. Ver Dominique Bolliet et Jean-Pierre Schmitt, La socialisation, Rosny-sous-Bois, Bréal, 2008, 2e édition, p. 21.
} 


\section{O FOCAC e a construção de uma identidade compartilhada}

Os mecanismos de construção desta identidade se manifestam através da evocação contínua de um passado comum e, sobretudo, pela auto-identificação da China com o Terceiro-Mundo, do qual a África é parte. O vocabulário engajado, que converge essencialmente em torno de expressões chave, como "interesses comuns", "necessidades mútuas", "confiança mútua", ilustra o desejo de criar um laço de identidade.

Primeiramente, percebe-se uma recorrente lembrança do "passado comum", a partir do qual aspira-se legitimar um destino comum. Tendo vivido a dominação ocidental no passado, o FOCAC é o lugar para recordar (escondendo as dificuldades encontradas em certos países) que a China e a África sempre demonstraram simpatia e apoio às lutas de libertação nacional, e forjaram, entre elas, uma "amizade profunda". Aqui, os dirigentes chineses reforçam a militância revolucionária e a solidariedade terceiro-mundista dos anos 1950 à 1970, e conclamam o surgimento de um "futuro luminoso". Durante o seu discurso na inauguração do FOCAC em Pequim, o presidente Jiang Zemin declarou: "Ao longo do século XX, os povos chinês e africano lutaram firmemente e avançaram em ondas sucessivas até a conquista da independência e da liberdade nacional e para alcançar a paz e o desenvolvimento. (...) Depois de acabar com o jugo da dominação colonial, muitas vezes secular, os povos africanos conquistaram a libertação nacional e tornaram independentes seus Estados.(...) O povo chinês, por sua vez, derrubou três grandes montanhas: o imperialismo, o feudalismo e o capitalismo burocrático, e proclamou a República Popular da China, da qual ele é o mestre ${ }^{31}$.

A história é utilizada para justificar as relações atuais. Os discursos chineses se combinam para fazer ressurgir a origem dos contatos com a África em um passado distante. Como lembrou o presidente Hu Jintao no FOCAC III, em Pequim: "Apesar da distância geográfica, a amizade sino-africana mergulha suas raízes na profundidade do tempo, e não para de se aprofundar com o passar dos anos". É a razão pela qual, quando se fala das relações com a África, sempre há uma referência ao contexto histórico.

Pequim insiste na questão histórica por diferentes razões: enfatizar a antiguidade e a continuidade dessas relações; focar a atenção em um passado de valores comuns (colonialismo, racismo, terceiro mundismo, anti-hegemonismo); conciliar seu status de potência mundial emergente com sua identidade terceiro-

\footnotetext{
31"Para uma cooperação sino-africana mais solidária no contexto de um novo século", discurso do presidente Jiang Zemin na cerimônia de abertura do FOCAC I, Pequim, 10 de outubro de 2000.
} 
mundista. Nesse sentido, o premiê chinês, Wen Jiabao, declarou em seu discurso na cerimônia de abertura da quarta Conferência Ministerial do FOCAC, em Sharm elSheikh: "Eu gostaria de reforçar aqui que nem a presença chinesa na África, nem o apoio dos países africanos à China datam de hoje. Já nos anos 50 e 60 do século passado, a China e a África combateram lado a lado na luta contra o imperialismo, o colonialismo e o hegemonismo, e avançaram, de mãos dadas, no árduo caminho de recuperação da economia nacional" 32 .

Assim, a equipe dirigente chinesa tende sempre a apresentar a China aos parceiros africanos do FOCAC reforçando sua natureza de país em desenvolvimento: "a China é o maior país em desenvolvimento do mundo, enquanto que o continente africano, por sua vez, reúne o maior número de países em desenvolvimento" ${ }^{33}$. Essa identificação tem uma conotação altamente política, uma vez que, é importante lembrar, é menos sobre os critérios econômicos do que políticos que a China se apresenta como um país do Terceiro-Mundo. Este último é entendido, na verdade, como o mundo dos povos oprimidos e submetidos pela dominação dos Estados imperialistas ${ }^{34}$. Essa escolha de identidade é feita apesar do fato de a China, pelo seu peso econômico e seus ativos políticos (membro permanente do Conselho de Segurança da $\mathrm{ONU}$, potência nuclear) ser mais semelhante às grandes potências do norte, que influenciam nas relações internacionais. Essa opção é relativamente facilitada pelo fato de que é difícil classificar a China apenas em uma categoria, uma vez que ela é, ao mesmo tempo, país do Terceiro Mundo e potência de influência mundial. Além disso, ao contrário de vários países do norte, ela produziu em conjunto com os países africanos, em questões essenciais para eles, normas nas quais eles se reconhecem.

\section{O FOCAC como instância de promoção de normas}

A China desenvolveu uma visão das relações internacionais que dá uma clara preferência ao respeito da soberania de seus parceiros e à primazia do desenvolvimento econômico. Essas prioridades se opõe diametralmente à primazia das liberdades individuais e à importância de reformas políticas, promovidas pelo mundo ocidental. Uma análise dos documentos importantes do FOCAC (Declarações

\footnotetext{
32 Discurso de Wen Jiabao na cerimônia de abertura do FOCAC IV, Sharm el-Sheikh, 8 de novembro de 2009.

${ }^{33}$ Discurso do presidente Jiang Zemin na cerimônia de abertura do FOCAC I, Pequim, 10 de outubro de 2000.

34 François Joyaux, La tentation impériale. Politique extérieure de la Chine depuis 1949, Paris, Imprimerie nationale, 1994, p. 329.
} 
e Planos de Ação) permite constatar que, dentro da instituição, as partes se comprometem a estabelecer e trabalhar para a implementação de certos costumes e práticas normativas como a sacralização do princípio da soberania do Estado e da reforma do sistema econômico internacional.

Primeiramente, o princípio da soberania se tornou um dos norteadores dos governos chineses desde a fundação da RPC. Ele transparece práticas discursivas e diplomáticas da China, que regular e assiduamente evoca a soberania como sendo a base das relações internacionais contemporâneas e do direito internacional ${ }^{35}$. $O$ corolário é o de que o princípio da inviolabilidade da soberania estatal é uma característica distintiva da concepção chinesa do direito internacional. $O$ conceito de soberania e, em particular a doutrina de "inviolabilidade da soberania", são desenvolvidos como uma "arma defensiva" contra a ingerência nas questões internas ${ }^{36}$. Essa doutrina tradicional e rígida do princípio de soberania é lembrada nos discursos e documentos do FOCAC. O presidente Jiang Zemin afirmou, nesse sentido, na inauguração do FOCAC em 2000, que "da história do século passado, nós podemos tirar a seguinte conclusão: os povos da China e da África são ferozmente ligados às suas independências nacionais".

Esse conceito muito se explica pela necessidade de isolar Taiwan, na incapacidade chinesa de incorporá-la à RPC. Daí resulta a "One China policy", que estabelece a restrição das relações diplomáticas aos Estados que reconhecem exclusivamente a República Popular da China. Os países africanos membros do FOCAC não estão descontentes, já que apoiam, em suas declarações, o projeto de ver se realizar "a nobre causa da reunificação pacífica da China".

Este é um padrão perfeitamente compartilhado na África. Deve-se lembrar, na verdade, que os princípios da soberania e intangibilidade das fronteiras resultantes da colonização são centrais nas relações interestatais africanas. Eles foram não apenas os princípios fundadores da Organização da Unidade Africana (OUA) nos anos 1960, mas também explicam em grande parte a sobrevivência dos

35 Wang Tieya, "International Law in China", 221 Collected Courses of The Hague Academy of International Law, $\mathrm{n}^{\circ}$ 2, 1991, p. 288.

36 Jerome Cohen et Hungdah Chiu, People's China and International Law: a Documentary Study, Princeton, Princeton University Press, 1974, p. 117-118; Shan Wenhua, « Redefining the Chinese concept of sovereignty » in Wang Gungwu et Zheng Yongnian (dir.), China and the New International Order, London, Routledge, 2008., p. 53-80. 
Estados africanos fracos, multiétnicos e com fronteiras recortadas, por vezes ao acaso, definidas pelos colonizadores ${ }^{37}$.

Em segundo lugar, chineses e africanos exigem uma reforma da ordem econômica internacional. Os dirigentes chineses se comprometem publicamente a promover o estabelecimento de uma "ordem comercial multilateral justa e racional" e a aumentar o poder de voz e de decisão dos países em desenvolvimento nos assuntos financeiros internacionais. De acordo com os termos da Declaração de Pequim de 2006: "(...) Os ministros unanimemente concordam que, tendo em conta a atual ordem internacional, injusta e desigual, a China e os países africanos devem se esforçar para influenciar o estabelecimento de uma nova ordem internacional que responda às suas necessidades e interesses" 38 .

Lembramos que no início dos anos 1980, a China já havia militado contra a deterioração dos termos de troca e, portanto, para o equilíbrio do comércio internacional entre o preço das matérias-primas e dos produtos manufaturados importados pelos africanos. Na mesma ótica, os chineses, sabe-se, dão prioridade ao desenvolvimento econômico em relação à reforma política. O centralismo político oferece um ambiente estável, sem o qual não pode haver reforma econômica ${ }^{39}$. Os países africanos que, em parte sob a pressão das potências ocidentais, tem se envolvido, desde o início dos anos 1990, em processos de reforma política com resultados negativos, não podem não ser sensíveis a uma tal concepção. Dentro do FOCAC, a mensagem chinesa ligada a esse princípio é bem recebida na África: "Nós sublinhamos que a diversidade do mundo deve ser respeitada e preservada, que todos os países do mundo, grandes ou pequenos, ricos ou pobres, fortes ou fracos, devem ter grande estima mútua, tratar-se igualmente e viver na paz e na amizade, e que as diferentes civilizações e as diversas formas de desenvolvimento devem se inspirar umas nas outras, progredir conjuntamente e coexistir em harmonia ${ }^{40 "}$.

O FOCAC se tornou uma instituição renovadora, em muitos aspectos, das relações internacionais das partes envolvidas. Isso significa que esta instituição afeta as partes, é afetada por elas, ou produz resultados iguais para China e África?

\footnotetext{
37 Robert H. Jackson and Carl G. Rosberg "Why Africa's Weak States Persist: The Empirical and the Juridical in Statehood», World Politics, Vol. 35, No. 1 (Oct., 1982), pp. 1-24.

38 Preâmbulo do Programa de Cooperação Sino-Africana sobre o desenvolvimento econômico e Social. Pequim, outubro de 2000.

${ }^{39}$ Zhiming Chen, "La voie chinoise de développement”, Études internationales, vol. XLI, n 4, 2010 , p. 455-483.

${ }^{40}$ Declarações da Cúpula de Pequim sobre a Cooperação sino-africana, 16 de novembro de 2006.
} 


\section{O FOCAC: um multilateralismo assimétrico?}

Apesar do estabelecimento de uma identidade comum e de normas compartilhadas, o FOCAC, à semelhança de outras instituições multilaterais internacionais, é fortemente instrumentalizado. Essa instrumentalização deve ser considerada tanto no caso do membro mais poderoso do FOCAC - a China - quanto no caso dos membros africanos, a priori menos influentes. Se trata mais de desequilíbrio ou de assimetria.

A forma hierárquica dessa instituição torna possível, para a China, defender as causas africanas servindo seus próprios interesses, sejam eles materiais ou simbólicos. Esse reagrupamento permite também aos pequenos Estados da África existir no cenário internacional, compensando a sua falta de poder e, "apesar dos recursos limitados, de sair, mesmo que apenas simbolicamente, de sua própria área geográfica"41. Esse espaço serve como um amplificador de suas reivindicações (respeito à soberania, melhor representatividade nas instituições financeiras mundiais, etc.). De resto, em um contexto de rarefação da ajuda e da assistência tradicional, a China representa no âmbito do FOCAC, uma alternativa amplamente apreciada pelas autoridades políticas africanas. Altamente significativo a este respeito é a recepção favorável das "generosidades" chinesas e de sua capacidade para cumprir os compromissos atuais e futuros. Isso é ilustrado pelas palavras de Denis Sassou Nguesso, presidente do Congo (Brazzaville) e então presidente em exercício da União Africana: "Como de costume, as autoridades chinesas tem mantido a sua palavra"42.

Por causa do desequilíbrio existente entre a líder China e os países africanos, alguns geralmente percebem o FOCAC como um instrumento inteiramente a serviço da nova política econômica da chinesa na África. Falando sobre a Cúpula de Pequim, um autor escreveu: "E é efetivamente a China que convidou seus novos parceiros comerciais a vir passar alguns dias em Pequim"43. Até certo ponto, não podemos refutar a existência de várias formas de assimetria nesse fórum. Dito de outra forma, constata-se efetivamente que a relação é frequentemente apresentada e percebida no sentido China-África, e não África-China, mesmo que a África represente uma parte importante nesse conjunto e forneça recursos imensos ao crescimento chinês.

41 Bertrand Badie, "Le défi de la puissance" in Bertrand Badie et Guillaume Devin (dir.), Le multilatéralisme: nouvelles formes de l'action internationale, Paris, La Découverte, 2007, p. 215-232. 42 “Main basse sur l'Afrique”, Marchés Tropicaux \& Méditerranéens, 10 novembre 2006.

43 Antoine Kernen," Les stratégies chinoises en Afrique : du pétrole aux bassines en plastiques", Politique africaine, $\mathrm{n}^{\circ}$ 105, mars 2007, p. 163-180. 
No entanto, é a China, com sua forte capacidade econômica e financeira, que investe na África mais do que os países africanos na China. Além disso, é ela que faz promessas e realiza inúmeras obras em todo o continente africano. Na verdade, frente a uma China tão poderosa quanto resoluta a cumprir seus objetivos, os países africanos parecem mover-se em ordem dispersa, com uma visão nem sempre clara da oportunidade que poderia representar a ação coletiva africana em tal instituição. Apesar de algumas iniciativas da União Africana nesse sentido, os africanos não possuem um mecanismo estruturado e aparentam, pelo menos até agora, deixar o comando das operações para a China.

A heterogeneidade dos Estados africanos, que se encontram em diferentes fases de desenvolvimento, torna a operação complicada. A situação é bastante diferente, sendo o país economicamente sólido, ou não. A África do Sul, por exemplo, tem menos dificuldade de influenciar a agenda chinesa, uma vez que o país possui uma das infraestruturas viáveis e instituições capazes de monitorar o comportamento dos investidores estrangeiros ${ }^{44}$. Para os países menos avançados economicamente, a operação é bastante mais difícil, e o risco é que, não podendo influenciar a agenda com a China, as elites se utilizem das realizações do FOCAC para garantir a sua autoridade, em detrimento do desenvolvimento econômico e social de seus países. Este é o centro das preocupações ligadas à transparência e a governança dos fundos atribuídos no âmbito do FOCAC. A adesão à instituição pode, em certos casos, servir apenas para promover retornos financeiros pontuais, sem impacto real sobre a diversificação econômica e os padrões de vida das populações.

A não participação, no Fórum de Cooperação China-África, dos países que reconhecem a República da China (Taiwan), também demonstra o desequilíbrio existente dentro do FOCAC em favor da China. Dado que a política de "uma China" constitui a condição sine qua non de cooperação oficial com a China, os únicos Estados africanos ausentes do Fórum são aqueles que mantém relações com Taipei (Burkina Faso, Gâmbia, São Tomé e Príncipe e Suazilândia). A partir dessa perspectiva, a atitude chinesa é particularmente ambígua, podendo a soberania dos Estados africanos "amigos" ser excepcionalmente contornada quando isso importa para resolver uma questão interna: a questão de Taiwan.

A mesma análise pode ser feita relativamente à auto-identificação chinesa com o Terceiro-Mundo. Fundamentalmente, se trata, para a China, de conciliar sua

\footnotetext{
44 Sanusha Naidu, “The Forum on China-Africa Cooperation: What does the Future Hold?", China Report, vol. 43, n 3,2007 , p. 283-296.
} 
"identidade" de país terceiro-mundista com sua progressão rumo ao status de potência de influência mundial. A China, de fato, sempre lutou contra o isolamento e busca manter uma especificidade "chinesa" ao tentar completar a sua integração à comunidade internacional. A política exterior chinesa continua, sobretudo hoje em dia, a ser motivada pelos interesses nacionais mais do que pela ideologia. E a autoidentificação terceiro-mundista contribui para a consecução dos objetivos fundamentais, que não mudaram com a renovação das diferentes equipes dirigentes: preservar a segurança nacional e promover o reconhecimento do lugar e do papel da China no mundo ${ }^{45}$. Desde a fundação da RPC, em 1949, a retórica política de Pequim deu grande prioridade às relações com a Ásia, a África e a América Latina, ou seja, o Terceiro-Mundo. Na realidade, a China tem seguidamente utilizado sua relação com o Terceiro Mundo, no caso com a África, para melhorar sua posição em relação aos EUA ou à União Soviética antes de seu desmantelamento. A teoria dos três mundos de Mao, bem como a oposição à hegemonia americana depois da Guerra Fria, tinham como objetivo criar coalizões capazes de limitar a influência da superpotência. Oficialmente, entretanto, a vontade de pertencer ao Terceiro-Mundo mobilizada dentro do FOCAC objetiva também garantir aos líderes africanos que, apesar de sua emergência à posição de potência mundial, a China continuará fiel aos interesses dos países em vias de desenvolvimento. Há aí, portanto, um dilema de política estrangeira, no qual a história é frequentemente utilizada como solução ${ }^{46}$.

Além disso, sobre a reforma das instituições financeiras e políticas internacionais, pode-se, com razão, ter reservas quanto às declarações oficiais chinesas. A RPC ambiciona verdadeiramente se opor ao clube exclusivo das potências que recorrem cada vez mais a uma "diplomacia de conivência 47 ", uma vez que ela faz parte dele? A universitária chinesa Wang Jisi destaca que seria irracional Pequim questionar diretamente a ordem internacional e as instituições favorizadas pelo mundo ocidental e que, em realidade, tal contestação é improvável ${ }^{48}$. Membro permanente do Conselho de Segurança com direito a veto, os interesses da China são, em certas perspectivas, tão conservadores quanto os dos países ocidentais. No que concerne a reforma da $\mathrm{ONU}$, é provável que a China não tenha nenhum interesse em ver o Japão chegar ao Conselho de Segurança, com medo de que isso interfira em seu destaque no ambiente asiático. Alguns observadores acreditam que os novos aliados

${ }^{45}$ Craig Harris et Robert Worden, China and the Third World, London \& Sydney, Groom Helm Ltd, 1986, p. 1-13

46 Chris Alden et Ana Cristina Alves, (2008), "History and Identity in the Construction of China's Africa Policy", Review of African political economy, vol. 35, $\mathrm{n}^{\circ} 115$, March, p. 43-58.

${ }^{47}$ Bertrand Badie, La diplomatie de connivence. Les dérives oligarchiques du système international, Paris, La Découverte, 2011.

48 Jisi, « Searching for Stability with America », Foreign Affairs, vol. 84, n 5, Sept/Oct. 2005, p. 39 48. 
africanos poderiam ajudar a China a impedir a entrada do rival japonês no Conselho de Segurança ${ }^{49}$. Isso mostra a capacidade de instrumentalização do FOCAC para servir nas batalhas internacionais da China.

\section{Conclusão}

A recepção africana do Fórum de Cooperação China-África tem sido, em geral, positiva, mesmo se, por razões diversas, alguns países têm expressado opiniões reservadas, incluindo a África do Sul que, por intermédio do ex-presidente Thabo Mbeki, continuou a alertar contra os desequilíbrios potencias da cooperação sinoafricana. Vimos que em certa medida, o FOCAC é uma instituição - desequilibrada de caráter multilateral, que garante a socialização, através de práticas compartilhadas por seus membros, mas também promove interesses e normas compartilhadas, como a soberania, a primazia do desenvolvimento econômico e os princípios de igualdade e equidade nas instâncias internacionais.

Essa concepção parece ser unanimidade entre os membros africanos do FOCAC. Nesse sentido, no lançamento do FOCAC III, o presidente argelino Abdelaziz Bouteflika reforçou esta convergência de pontos de vista nos seguintes termos: "A China e a África podem, de fato, contar com um novo tipo de parceria, mutuamente benéfica e que não sofre as consequências da história colonial e daquela prejudicial, induzida por uma ajuda paternalista ao desenvolvimento" $" 50$.

Para compensar os desequilíbrios (agenda, política de uma China única, etc.), que são indiscutivelmente favoráveis ao líder chinês no FOCAC, os países africanos deveriam também estar estreitamente envolvidos na administração e na coordenação do acompanhamento das decisões do FOCAC. Pode-se lamentar a timidez do engajamento africano: não existe um comitê de monitoramento em nível regional. Isso reforça a tendência bilateral das negociações tanto dentro quanto fora do FOCAC. Essa tendência ao bilatrealismo - que a China aprecia, paradoxalmente pode favorecer as práticas clientelistas de certos dirigentes.

O que aparenta ser um multilateralismo de aprendizagem poderia se revelar uma arma particularmente eficaz para tratar em bloco com outros parceiros

\footnotetext{
49 Ver William Leday, "Dimensions politiques du partenariat stratégique Chine-Afrique", Défense nationale et sécurité collective, janvier 2007, p. 95-102.

50 Declaração do presidente argelino Abdelaziz Bouteflika no lançamento da Cúpula China-Africa, disponível em <http://www.el-mouradia.dz/>, novembro 2006.
} 
extracontinentais, bem como em instâncias multilaterais internacionais. A União Africana parece ter compreendido a urgência da situação, adotando uma das recomendações de uma equipe especialmente contratada para refletir sobre as ações a serem adotadas em relação aos países emergentes. A equipe concluiu que a África deveria desenvolver uma estratégia clara para evitar reproduzir uma segunda colonização, e que deveria utilizar seus recursos naturais eficazmente para acelerar a industrialização do continente ${ }^{51}$.

Certamente, longe de ser exclusivamente motivado pela partilha idealista de valores e de interesses comuns, o FOCAC constitui um projeto marcado pela utilização do Soft Power $^{52}$, ou seja, da potência econômica e persuasiva, bem como da oferta de apoio político-diplomático da China para influenciar as escolhas dos países africanos. Mas essa instituição aparece também como um grupo multilateral que é usado pelos membros como um multiplicador de poder: é um retransmissor das reivindicações dos pequenos Estados africanos e do prestígio internacional da potência emergente que é a China. Se doze anos depois de seu lançamento os horizontes do FOCAC, a longo prazo, são pouco claros - deve-se, sempre, levar em conta os programas trienais Chineses - é certo, no entanto, que esta instituição serve aos seus membros na mesma medida que eles servem à ela.

\section{REFERÊNCIAS}

ALDEN Chris, ALVES Ana Cristina, (2008), "History and Identity in the Construction of China's Africa Policy", Review of African political economy, vol. $35, \mathrm{n}^{\circ} 115$, March, p. 43-58.

BADIE Bertrand, DEVIN Guillaume (dir.), Le multilatéralisme: nouvelles formes de l'action internationale, Paris, La Découverte, 2007.

BADIE Bertrand, La diplomatie de connivence. Les dérives oligarchiques du système international, Paris, La Découverte, 2011.

\footnotetext{
51 “African Countries Draft Plan for Relations with 'Emerging Powers' Like China, India and Brazil”, World Politics Review, 23 outubro $2006, \quad$ disponível $\quad \mathrm{em}$ http://www.worldpoliticsreview.com/articlePrint.aspx?ID=279

52 Joseph Nye, Soft Power. The Means to Success in World Politics, New York: Public Affairs, 2004.., p. 5-11.
} 
BOLLIET Dominique, SCHMITT Jean-Pierre Schmitt, La socialisation, Rosnysous-Bois, Bréal, 2008 (2édition).

CHEN Zhiming, "La voie chinoise de développement", Études internationales, vol. XLI, $\mathrm{n}^{\circ} 4,2010$, p. 455-483.

GOLDSTEIN Avery, “The Diplonmatic Face of China's Grand Strategy : A Rising Power'S Emerging Choice", The China Quarterly, vol. 168, 2001, p. 842844.

GOLDSTEIN Avery, Rising to the Challenge: China's Grand Strategy and International Security, Stanford, Stanford University Press, 2005.

GURTOV Melvin, VAN NESS Peter (dir.), Confronting the Bush Doctrine. Critical Views from South East Asia, Londres, Routledge, 2005.

HARRIS L. Craig, WORDEN Robert, China and the Third World, London \& Sydney, Groom Helm Ltd, 1986.

HE Wenping, "The Balancing Act of China's Africa Policy", China Security, vol. 3, $\mathbf{n}^{\circ} 3,2007$, p. $23-40$.

JACKSON Robert H., ROSBERG Carl G. «Why Africa's Weak States Persist: The Empirical and the Juridical in Statehood», World Politics, Vol. 35, No. 1 (Oct., 1982), p. 1-24.

JOYAUX François, La tentation impériale. Politique extérieure de la Chine depuis 1949, Paris, Imprimerie nationale, 1994.

KERNEN Antoine, "Les stratégies chinoises en Afrique : du pétrole aux bassines en plastiques", Politique africaine, $\mathrm{n}^{\circ} 105$, mars 2007, p. 163-180.

KIM Samuel, "China's International Organizational Behavior", in ROBINSON Thomas and SHAMBAUGH David (dir.), Chinese foreign policy: Theory and practice, Oxford, Oxford University Press, 1995, p. 401-434.

LEDAY William, "Dimensions politiques du partenariat stratégique ChineAfrique", Défense nationale et sécurité collective, janvier 2007, p. 95-102.

LI Weijian, Beijing Summit \& Third Ministerial Conference of the Forum on ChinaAfrica Cooperation - Appraisal and Prospects, Report of Shanghai Institute for International Studies (SIIS), décembre 2008.

MACLEOD Alex, DUFAULT Evelyne, DUFOUR Guillaume (dir.), Relations internationales. Théories et concepts, Montréal, Athéna éditions, $2004 \quad\left(2^{\mathrm{e}}\right.$ édition). 
NAIDU Sanusha, "The Forum on China-Africa Cooperation: What does the Future Holds?", China Report, Vol. 43, n 3, 2007, p. 283-296.

NEL Philip, MCGOWAN Patrick (dir.), Power, Wealth and Global Order, Rondebosch, University of Cape Town Press, 1999.

NYE Joseph, Soft Power. The Means to Success in World Politics, New York, Public Affairs, 2004.

SHAN Wenhua, "Redefining the Chinese concept of sovereignty" in WANG Gungwu, ZHENG Yongnian (dir.), China and the New International Order, London, Routledge, 2008, p. 53-80.

SHELTON Garth, "China, Africa and South Africa Advancing South-South Cooperation", in BORON Atilio and LECHINI Gladys, Politics and Social Movements in an Hegemonic World: Lessons from Africa, Asia and Latin America, Buenos Aires, Clasco, 2005, p. 347-383.

SHELTON Garth, PARUK Farhana, The Forum on China-Africa Cooperation: A Strategic Opportunity, Johannesburg, Institute for Security Studies, 2008.

T.V. Paul, Balance of Power. Theory and Practice in the 21st Century, ed. T.V. Paul et al. (dir.), Stanford, Stanford University Press, 2004.

TAYLOR Ian, China and Africa: Engagement and Compromise, London, Routledge, 2006.

TULL Denis, “China's engagement in Africa: Scope, Significance and Consequences", Journal of Modern African Studies, vol. 44, $\mathbf{n}^{\circ} 3,2006$, p. 459-479.

VERMANDER Benoît, Chine brune ou Chine verte? Les dilemmes de l'Etat parti, Paris, Presses de Sciences Po, 2007.

WANG Gungwu, ZHENG Yongnian (dir.), China and the new International Order, London, Routledge, 2008.

WANG Jisi, "Searching for Stability with America", Foreign Affairs, Vol. 84, n 5 , September/October 2005, p. 39-48.

WU Guogang, LANSDOWNE Helen, China Turns to Multilateralism: Foreign Policy and Regional Security, Londres, Routledge, 2008.

ZHAO Suisheng (dir.), Chinese Foreign Policy: Pragmatism and Strategic Behavior, Armonk, M.E. Sharpe, 2003. 
ZHENG Bijian, "China's Peaceful Rise to Great Power Status", Foreign Affairs, vol. 84, $\mathrm{n}^{\circ}$ 5, septembre/octobre 2005, p. 18-24. 


\section{RESUMO}

A emergência chinesa tornou-se evidente nos anos 2000, em um contexto de unilateralismo dos EUA, comandados por George Bush Jr. Esse contexto explica, em grande medida, as estratégias adotadas pela China para evitar o isolamento e defender seus interesses. É o caso do multilateralismo, anteriormente visto com desconfiança mas que tornou-se um elemento essencial de sua estratégia diplomática, especialmente em âmbito regional.

Nesse contexto, o FOCAC (Fórum de Cooperação China-África) apresenta-se como um grupo multilateral imperfeito, sabendo que as relações bilaterais são o núcleo das relações entre a China e os países africanos, Trata-se de uma organização no modelo de tantas outras, como a Commonwealth ou a Organização Internacional da Francofonia? Os países africanos são verdadeiros atores nessa instituição, ou eles gravitam em torno da China que, esta sim, define as normas e princípios e se beneficia sozinha?

Esse artigo tem dois objetivos. Primeiro, mostrar como o FOCAC participa da estratégia de construção de alianças, lhe permitindo resistir melhor ao unilateralismo americano e aos riscos de ser barrado por seus rivais ocidentais em geral. Em seguida, mostrar que, como instituição, o FOCAC é um verdadeiro lugar de socialização, isto é, de construção e difusão de normas, de práticas e de comportamentos para e entre os participantes e que longe de ser um simples instrumento manipulado pela China, ele é tanto uma estrutura quanto uma ferramenta com impactos compartilhados. Em um primeiro momento será esboçado, brevemente, o arcabouço teórico e conceitual construtivista que sustenta o argumento dos autores, recorrendo a conceitos de soft balancing e de socialização. Na seção seguinte, retoma-se o contexto de criação do FOCAC, destacando características institucionais e seu impacto nas relações sino-africanas.

\section{PALAVRAS-GHAVE}

Multilateralismo; Instituições Internacionais; FOCAC; Soft Balancing; Socialização; Relações Assimétricas. 


\title{
A POLÍTICA EXTERNA DO GOVERNO JACOB ZUMA: ASSOCIAÇÃ̃O OU DISSOCIAÇÃO?
}

\author{
Chris Landsberg ${ }^{1}$
}

\section{Introdução}

Como a África do Sul se aproxima do aniversário de terceiro ano do governo Jacob Zuma, é um momento oportuno para mapear algumas de suas trajetórias políticas. Neste ensaio, discutirei a política externa e os objetivos estratégicos dessa administração, com a avaliação de suas prioridades diplomáticas dominantes. $\mathrm{O}$ expresidente, Thabo Mbeki, possuía uma narrativa de política externa claramente articulada e altamente ambiciosa, da qual o novo presidente Jacob Zuma alegaria divergências. No entanto, quando o novo presidente finalmente conseguiu costurar sua política externa, ele acabou por se apoiar naquela formulada pelo próprio expresidente Mbeki. Além disso, a política externa de Zuma, como está escrita no papel, guarda pouca semelhança com a que está sendo implementada. Isso, juntamente com querelas e acusações de fraqueza de liderança da atual administração, implica em um elemento de confusão, cujas raízes podem ser encontradas na transferência de poder entre os dois líderes. Neste sentido, pode-se dizer que a política externa da África do Sul foi "Polokwanizada", uma referência às tensões entre o ex-presidente Thabo Mbeki e seu sucessor Jacob Zuma, e às implicações desta disputa sobre a política, em geral, e a política externa, em particular.

\section{A agenda da política externa do governo Zuma}

Enormes expectativas receberam o atual governo sul-africano na $52^{\text {a }}$ Conferência Nacional do Congresso Nacional Africano (CNA) em Polokwane, em 2007. Isso pelo menos entre os partidários da facção que tomou de Thabo Mbeki o controle do partido e o entregou a Jacob Zuma. Muitas dessas expectativas giravam

${ }^{1}$ Por Chris Landsberg, Professor do Departamento de Política, Universidade de Johanesburgo. (austral@ufrgs.br) 
em torno da ideia de que o golpe democrático ocorrido na política sul-africana traria não apenas uma mudança de personalidades, mas de políticas reais (Landsberg, 2011, p. 246).

Mbeki havia seguido uma abordagem fundada em quatro objetivos estratégicos, na qual ele procurou combinar políticas externa e interna (Landsberg, 2006, p.256). A chamada 'Agenda Africana'; a cooperação Sul-Sul; o diálogo NorteSul; e questões socioeconômicas e político-securitárias; todos esses pontos incorporaram o movimento do país na era pós-Apartheid que buscava combinar crescimento interno com a substituição do isolamento internacional por meio de ligações continentais e ultramarinas e de uma abordagem em direção à governança global (Landsberg, 2006, p.257).

Foi neste contexto que, em agosto de 2009, foi anunciado um Plano Estratégico de Médio Prazo para Guiar o Programa Governamental para o Mandato Eleitoral no período de 2009-2014². Esse plano sinalizou que a administração de Zuma defenderia a sua política externa sob a vasta rubrica da "Busca pelo Progresso Africano e do Reforço da Cooperação". O governo ergueu uma série de pilares, marcadamente similares àqueles de Mbeki, nomeadamente:

(1) preencher a lacuna entre política interna e externa, ou os chamados interesses nacionais;

(2) promover a integração da Comunidade de Desenvolvimento da África Austral (SADC)

(3) priorizar o continente africano através do "Avanço Africano" (African advancement);

(4) fortalecer as relações Sul-Sul;

(5) melhorar as relações estratégicas com o Norte;

(6) reforçar as relações políticas e econômicas, e

(7) participar do sistema global de governança.

\footnotetext{
2 Medium-term Strategic Framework to Guide Government's Programme for the Electoral mandate Period 2009-2014.

3 Southern African Development Community
} 
O cimento destinado a unir o edifício que estes pilares deveriam suportar foi manifestado como 'interesse nacional', mas logo se tornou aparente que as fundações em si poderiam não ser capazes de suportar o peso deste edifício. Para os observadores críticos, logo se transformou em uma questão central o fato de se estes objetivos de política externa representaram uma mudança acentuada, ou apenas um reforço dos perseguidos por Mbeki, e porque houve tantas variações e divergências na sua implementação. Se Zuma quis divergir da agenda de Mbeki, por que ele a adotou em primeiro lugar? Alternativamente, teria Zuma sido pego entre os reformadores entusiastas que o colocaram no poder e os poderes reais capazes de colocar a sua política em prática?

\section{Dos Assuntos Externos às Relações Internacionais e Cooperação}

Em uma das primeiras medidas anunciadas pela Ministra NkoanaMashabane, de acordo com a resolução adotada pelo Congresso Nacional Africano em Polokwane, o nome do departamento responsável pela gestão a e coordenação da diplomacia e da política externa da República mudaria de Departamento de Assuntos Externos (DFA) para Departamento de Relações Internacionais e Cooperação (DIRCO). A ideia por trás disso era a de sinalizar a intenção do governo Zuma de introduzir um novo estilo e uma nova abordagem para a condução dos assuntos externos. A ênfase agora estava na colaboração e na atitude nãohegemônica que apregoava o chamado 'balanceamento suave', no qual as táticas de intimidação dos sucessivos governos do Apartheid haviam sido substituídas por acordos com as potências estrangeiras visando um reconhecimento mútuo e os interesses de cada parte.

Em seu primeiro discurso público como nova Ministra, Nkoana-Mashabane explicou o raciocínio por trás da mudança do nome, afirmando que se destinava a "refletir o novo foco que nosso governo deseja colocar sobre as parcerias e sobre a cooperação para o desenvolvimento". Em um discurso na Conferência dos Chefes de Missão do DIRCO, em agosto de 2009, ela expandiu essa motivação quando afirmou que "foi em grande parte influenciada por tendências internacionais que obrigam os Estados a pôr ênfase na cooperação ao invés da competição, e na colaboração ao invés do confronto". A Ministra foi além, realçando que "a natureza globalizada do mundo exige que os Estados continuem a criar melhores formas de cooperação entre si" (Nkoana-Mashabane, 2009a).

Outra motivação por trás da mudança no nome do Departamento relacionase à tentativa de redução da lacuna entre os assuntos nacionais e estrangeiros, mas 
também como forma de desmistificar o último e torná-lo acessível ao público. Nas palavras da Ministra, "uma das áreas importantes do nosso trabalho será fazer com que os sul-africanos estejam cientes do trabalho do Departamento. Neste sentido, pretendemos reforçar as nossas iniciativas de diplomacia pública e aumentar o nível de nosso compromisso com os sul-africanos em assuntos de política externa". E para ganhar o apoio da população, ela afirmou, "nosso trabalho precisa ser conhecido e compreendido pelos sul-africanos de todos os estratos". Isso exigiria "uma maior clareza e um maior foco no papel do Departamento e no cumprimento de nossas prioridades nacionais através de parcerias internacionais e de cooperação" (NkoanaMashabane, 2009b). A Ministra estava implicitamente reconhecendo que havia a necessidade de o governo melhorar suas estratégias de aproximação entre a política externa e interna. Havia, no mínimo, uma expectativa de que o governo comunicasse para o público doméstico de forma mais eficaz as lógicas que sustentavam a sua política externa.

Durante o seu Programa de Divulgação na Universidade de Limpopo em outubro de 2009, a Ministra articulou uma visão de interesse nacional que desafiou a noção realista de poder e de dominação, preferindo uma noção que envolveria cooperação e parceria, e reconheceu a sua complexidade. Este versátil adesivo, "interesse nacional", reuniu as "ambições e objetivos do país; os quais estão relacionados com a sobrevivência do Estado, estendendo-se à sua busca por riqueza, crescimento econômico e poder". O DIRCO anexou grande valor para o balanceamento suave, estabelecendo uma conexão muito próxima entre política externa e a interna:

Nós não acreditamos que o sistema internacional é caracterizado pela
anarquia e que os Estados têm de se esconder atrás da capa de sua
soberania e focar estritamente na busca de seu interesse nacional. No
esquema dos interesses nacionais da África do Sul, os Estados podem
trabalhar juntos em torno de uma agenda global comum e de valores
compartilhados por um mundo melhor. (Nkoana-Mashabane, 2009c).

No entanto, se essa retórica se destina a sinalizar uma mudança fundamental na política do novo governo, ela teria que ir mais longe do que uma mudança nominal. Examinadas de perto, tanto a presidência de Mandela quanto a de Mbeki há muito denunciaram as abordagens hegemônicas para assuntos internacionais em favor de promessas públicas de cooperação e de construção de parcerias. No continente africano, em especial, a "nova África do Sul" adotou de forma consistente uma postura de parceria, ao menos em uma tentativa de tranquilizar seus vizinhos sobre suas boas intenções, e anunciando que pretendia ser um parceiro pacífico e confiável, que não se empenharia em perseguir seu próprio interesse à custa daqueles países. 


\section{Estabelecendo uma Agência Sul-africana de Desenvolvimento}

Mas, além da mudança de nome, o que mais havia de novo? Outra ideia noticiada pelo novo governo de Zuma foi o estabelecimento de uma Agência SulAfricana de Parceria e Desenvolvimento (SADPA) ${ }^{4}$, com o objetivo de promover parcerias para o desenvolvimento. Segundo a Ministra Nkoana-Mashabane (2009c), o novo governo pretendeu reunir o trabalho de vários departamentos em uma unidade administrativa mais ágil. A visão que emanava de Pretoria-Tshwane era de integração entre "cooperação", "coordenação" e "coerência". Em agosto de 2009, a Ministra confirmou que a SADPA estava operacional, e iria "contribuir para a capacidade e o fortalecimento institucional, bem como apoiar o desenvolvimento de recursos sócio-econômicos e humanos" (Nkoana-Mashabane, 2009c).

No entanto, embora a ideia da SADPA tenha sido apresentada para trazer ordem ao caos anterior, não produziu novidade alguma. $O$ primeiro exemplo concreto que traduz essa visão cooperativa em um programa de ação já havia sido estabelecido por Mbeki para transformar a África do Sul em um país doador virtual, disposto a colocar recursos substanciais à disposição do "Renascimento Africano". Isso também se destinava a combater a hegemonia ocidental sobre o continente, e sinalizava para os parceiros continentais que as relações neocoloniais deveriam ser desafiadas. Em 2000, passado apenas um ano de presidência de Mbeki, a África do Sul estabeleceu o Fundo para o Renascimento Africano e a Cooperação Internacional $^{5}$ (ARF, 2000, Act 51, seção 2), tornando-se efetivamente um país doador africano, capaz de influenciar a política continental de forma mais direta. $\mathrm{O}$ país revertera o escopo do Fundo de Empréstimo para a Cooperação Econômica ${ }^{6}$ (Lei 68 de 1968), que havia sido utilizado pelo Estado do Apartheid para atrair os Estados africanos relutantes a cooperar. Em termos de estrutura, o ARF estava sob o controle do Diretor-Geral de Assuntos Externos. Fundos para projetos eram desembolsados após a aprovação do Diretor-Geral ou do próprio Ministro dos Assuntos Externos (DFA, 2008).

O Departamento de Assuntos Externos (DFA) também poderia recorrer aos seus próprios recursos departamentais e reclamar a sua devolução após aprovação do Ministro das Finanças. Empréstimos ou assistência financeira eram concedidos em conformidade com acordos celebrados entre o país em questão e o Ministro SulAfricano de Assuntos Externos. A ajuda concedida estava sujeita aos termos e condições estabelecidos pelo país beneficiário e pelo Ministro, e em todos os casos em

\footnotetext{
4 South African Development Partnership Agency

${ }^{5}$ African Renaissance and International Co-operation Fund

${ }^{6}$ Economic Co-operation Loan Fund
} 
consulta com o Ministro das Finanças (DFA, 2008). Um comitê consultivo foi criado para gerir o Fundo, e foi lhe dada a tarefa de fazer recomendações ao Ministro sobre o desembolso de fundos através de empréstimos e ajuda financeira aos demais países. O ARF impulsionou efetivamente a África do Sul no sentido de desafiar a hegemonia dos doadores estabelecidos. Seu objetivo era "promover a cooperação entre a República da África do Sul e outros países através da concessão de empréstimos e/ou concessão de apoio financeiro para projetos de desenvolvimento em outros países". $O$ fundo fora estabelecido para promover "de um modo pró-ativo" as seis áreas prioritárias que seguem (DFA, 2008):

(1) Cooperação entre a República da África do Sul e outros países, em particular países africanos

(2) Promoção da democracia e da boa governança

(3) Prevenção e resolução de conflitos

(4) Desenvolvimento socioeconômico e integração

(5) Assistência humanitária

(6) Desenvolvimento de recursos humanos

Em 2007, o ARF havia construído um forte histórico de financiamento multilateral e bilateral na África. Naquele momento, o governo reconheceu a necessidade de desenvolver para a República um programa político de ajuda ao desenvolvimento. $O$ palco estava armado para a África do Sul se tornar um doador de pleno direito que competiria e desafiar os doadores estabelecidos na África. $O$ DFA e o Tesouro haviam tomado a dianteira em 2005 ao trabalhar em uma estratégia para transformar o ARF no, mais coerente, Programa e Fundo de Assistência para o Desenvolvimento da África do Sul 7 , enquanto um memorando detalhado do Gabinete foi preparado para enunciar os seus princípios (DFA, 2008). A África do Sul participou do chamado "mecanismo do Clube de Paris", que focou a atenção no fluxo de ajuda, na reforma substancial de políticas de ajuda obsoletas e ineficazes e na gestão que favorecesse o apoio orçamentário em oposição à ajuda condicionada (tied aid). Uma avaliação global do progresso foi feita em questões tais como o alcance dos indicadores da Declaração de Paris. O governo Mbeki foi tão sério sobre jogar no nível estratégico de financiamento que explorou a ideia de

\footnotetext{
${ }^{7}$ Development Assistance Fund and Programme for South Africa
} 
dobrar a ajuda à África até 2010, e programou para 2015 a alocação para a ajuda de não menos de $0,7 \%$ da renda anual.

O documento de 2007 sobre a estratégia de como se tornar um Estado doador considerava tanto o financiamento multilateral e como o bilateral, e admitiu que o último exigiria ampla infraestrutura, a fim de garantir a sua eficácia. A África do Sul precisaria trabalhar para reforçar essa infraestrutura, e teria que aprender com o Departamento Britânico de Desenvolvimento Internacional (DFID), a GTZ da Alemanha, a Agência Americana para o Desenvolvimento Internacional (USAID), Agência Canadense de Desenvolvimento Internacional (CIDA), os doadores escandinavos e outros. Se fosse bem sucedido como um país doador estaria então em posição de influenciar a OCDE e o Clube de Paris, para garantir que a ajuda se torne mais alinhada com as agendas nacionais de desenvolvimento dos países em desenvolvimento, e ao mesmo tempo fazer campanha para uma redução da ajuda condicionada. A efetivação desse projeto daria a África do Sul uma voz para pressionar por maiores níveis de ajuda a serem alocados para o continente e para outros países em desenvolvimento e economias emergentes.

A questão sobre quão longe esta política foi continuada por Zuma e quão longe ela foi substituída por uma nova está intimamente relacionada com a crescente preocupação com o compromisso do governo em realizar o objetivo de estabelecer a sua agência em meio a uma recessão econômica global, bem como atender aos desafios socioeconômicos domésticos. Assim como está em uma grande crise de provimento de serviços, o governo do CNA enfrenta ataques de sua base tradicional de apoio, os sindicatos, e atualmente está travando bloqueios com a mídia, enquanto tenta amordaçar a liberdade de expressão em uma vã tentativa de impedir a divulgação de críticas do presidente e da corrupção generalizada que tem permeado todos os níveis do governo e do serviço civil.

À medida que a visão de Mbeki de um Renascimento Africano parece estar caindo no esquecimento, por causa do desejo pela nova elite dominante de se distanciar do ex-chefe de Estado, o governo tem mostrado poucos sinais de tornar operacional a sua agência de cooperação. Se e quando ele fizer isso, é duvidoso que será capaz de continuar a prosseguir os objetivos gerais promovidos pelo ARF, ou seja, a democracia e a boa governança, a prevenção e a resolução de conflitos; o desenvolvimento socioeconômico e a integração; a assistência humanitária e o desenvolvimento de recursos humanos. Mais provavelmente, ele terá de aperfeiçoar e racionalizar essas metas para algo menos ambicioso, talvez uma área nicho de construção do Estado democrático. Além disso, existem desafios políticoinstitucionais, tais como onde situar a agência, seja como parte do DIRCO, como órgão estabelecido no Tesouro, ou como uma entidade em si separada. Qualquer que 
seja a rota que o governo decida, uma coisa é certa, haverá a necessidade de existir um alto grau de cooperação entre DIRCO e uma série de outros departamentos, em especial da Presidência, o Tesouro, o Departamento do Comércio e da Indústria (DTI), o Departamento de Administração e Serviços Públicos (DPSA) e outros. O que mais preocupa é se o governo está realmente comprometido com a realização da meta ambiciosa de deixar de lado $0,7 \%$ do PIB para a ajuda externa, quando a sua própria população está manifestando inquietação crescente com o que é amplamente percebido, com ou sem razão, como governança caótica.

\section{Buscando o Avanço Africano}

A dimensão-chave da política externa do governo Zuma, como foi o caso com Mbeki, tem sido a "priorização contínua do continente africano", buscada no âmbito de duas grandes áreas temáticas: a melhoria da integração política e econômica continental e a Comunidade para o Desenvolvimento da África Austral (SADC). No entanto, por trás da retórica da mudança, há mais uma vez uma nota de familiaridade. Estratégias que desfilam sob o rótulo de "Avanço Africano" revelam uma política que empresta profundamente a noção do governo de Mbeki de "Agenda Africana", como explicitado por Nkoana-Mashabane, quando anunciou que "a consolidação da Agenda Africana continua sendo central para os nossos objetivos de política externa" e que o novo governo "continuará a trabalhar para alcançar uma visão da África unida, pacífica e próspera" (Nkoana-Mashabane, 2009c).

Especulações também têm sido frequentes quanto ao futuro da Nova Parceria para o Desenvolvimento da África ${ }^{8}$ (NEPAD) na abordagem de tipo regador (destituída de um foco específico) para a política externa por parte dos políticos de Zuma. Veio como novidade quando o governo começou recentemente a afirmar em público que permaneceu comprometido com o NEPAD. Isso porque havia ficado em silêncio sobre esta questão na maior parte de seus primeiros três anos e porque corre o risco, como um Estado líder na formação do NEPAD, de se distanciar da política interna a favor de sonoras razões de política externa. Na prática ainda há muita incerteza sobre o futuro deste programa. Ao comprometer-se, relutantemente, com o NEPAD, e ao melhorar o clima regional para o crescimento e desenvolvimento, assim como inserir os requerimentos de desenvolvimento do continente na agenda global, o governo está demonstrando que continuará a usar os veículos de Mbeki, o Plano de Ação G8-África e o Fórum de Parceria com a África. No entanto, ele não

${ }^{8}$ The New Partnership for Africa's Development. 
vai seguir o seu antecessor em anunciar esta, ou mesmo qualquer orientação política, como sendo de interesse nacional, a despeito de o NEPAD continuar sendo o principal quadro de referência para as relações intra-africanas e para a parceria da África com seus parceiros internacionais, como a Parceria Estratégica da ÁfricaUnião Européia (UE), o Fórum de Cooperação entre China e África (FOCAC), o G8, a Nova Parceria Estratégica África-Ásia (NAASP), e a Organização para a Cooperação e o Desenvolvimento Econômico (OCDE) (Nkoana-Mshabane, 2009c). Amplamente considerada como um pouco mais do que uma tertúlia, é difícil ver como Zuma poderia convencer sua audiência interna dos benefícios de continuar membro desses grupos, mesmo se ele mesmo soubesse.

Esses temores refletem também na relação do governo com o Mecanismo Africano de Avaliação pelos Pares ${ }^{9}$ (APRM), cuja implementação ele inicialmente apoiou. Existem agora sérias dúvidas sobre o futuro deste instrumento de governança, e quase um ano depois de que Chris Stals deixou o cargo de representante sul-africano no Painel de Personalidades Eminentes, apenas no início de 2012 fomos informados que a presidente do CNA, Baleka Mbete, substituirá Stals cinco anos depois que ele abdicou da posição. Isso não demonstra uma boa liderança, somado ao fato de que há questionamentos sobre o futuro do mecanismo internamente e sobre a implementação do plano de ação. As tensões entre o governo e a sociedade civil a respeito do processo e das estruturas internos do APRM estão bem documentadas, mas as tensões e os problemas persistem, com ambos os lados tendo algumas respostas a dar sobre como eles pretendem restaurar a credibilidade do instrumento.

O governo Mbeki repetidamente enfatizou a necessidade de reforçar a União Africana (UA) e suas instituições dentro do contexto de debate da Grande África. Sobre o governo da UA, a sua posição foi a favor não dos Estados Unidos da África (USAf) de Gaddafi, mas da União dos Estados Africanos. Novamente, houve uma oportunidade para o governo Zuma ir além das deliberações cautelosas de seu antecessor e abraçar uma visão federal para o continente. No entanto, uma vez mais, seu compromisso declarado de apoiar o velho paradigma de construção de uma União de Estados Africanos e de continuar a trabalhar para o fortalecimento da UA e de suas instituições confederadas o colocou firmemente nos passos do homem cujo golpe de Estado tinha derrubado: "A África do Sul vai continuar a defender uma abordagem gradual e incremental, concentrando-se nas organizações regionais, como blocos de construção em direção ao Governo da União, a abordagem da África do Sul continua a se basear no entendimento de que "a União Africana é uma união

\footnotetext{
${ }^{9}$ African Peer Review Mechanism.
} 
Estados soberanos e independentes", e que as ações da UA "são contingentes sobre o mandato dos Estados membros" (Nkoana-Mashabane, 2009c). Não é de surpreender, à luz de tal dogma intelectualmente falido, que os problemas críticos enfrentados pelo continente e pelo país possam encontrar quaisquer soluções rápidas e de longo prazo.

De maneira característica, substituindo retórica por política substantiva, a política declarada ressaltou que iria, através de questões continentais e regionais, trabalhar em direção ao fortalecimento da democracia e do respeito pelos direitos humanos no continente Africano (Nkoana-Mashabane, 2009c). Basta lembrar aqui que o equilíbrio entre direitos humanos e justiça em relação a uma abordagem de segurança, paz e desenvolvimento tem sido uma tarefa difícil para este país alcançar no decurso dos últimos quinze anos.

Já existe muita expectativa nas mídias local e internacional de que o governo Zuma prosseguirá uma política externa pró-direitos humanos, mas isso resiste a um exame minucioso? A apresentação das expectativas, sem contar a sua execução, terá de ser cuidadosamente gerida, para que a política externa não se torne apenas outro pedaço de superficial discurso internacional de direitos humanos.

Em consonância com sua abordagem neofuncionalista, as estratégias da política externa de Mbeki compreendiam o fortalecimento da União Africana (UA) e das suas instituições, como parte essencial para o fortalecimento da unidade e do desenvolvimento da África. O governo de Zuma prometeu continuar a contribuir para os órgãos da UA, nomeadamente instituições financeiras, tais como o Banco Central Africano, o Fundo Monetário Africano e o Banco Africano de Investimento, bem como a Corte Africana de Justiça e a Corte Africana de Direitos do Homem e dos Povos. Como anfitriões do Parlamento Pan-Africano, a África do Sul considera ter "uma responsabilidade especial em assegurar que este órgão da UA goze de legitimidade e eficácia no seu mandato" (Nkoana-Mashabane, 2009c). As políticas salientam a necessidade de garantir os recursos necessários e o apoio político para concretizar estes objetivos, mas assim como com as promessas de crescimento econômico sustentado e equitativo no continente africano, isso mostra mais uma vez, como a Ministra de Relações Internacionais revelou em numerosas ocasiões, que a abordagem de desenvolvimento para a política externa é de fato semelhante à postura adotada pela administração Mbeki. 


\section{A abordagem do governo Zuma para a resolução de conflitos em África}

A administração de Zuma evitou usar a ideia evocativa e controversa da "diplomacia silenciosa" como um meio de promover a resolução de conflitos na África. Distanciar-se desse conceito controverso foi uma tentativa de mostrar uma ruptura entre a sua administração e a de Mbeki. Mas para além de ter se livrado do termo "silenciosa", na prática, a postura adotada por Zuma na resolução de conflitos foi semelhante à adotada pela administração de Mbeki. Em seu primeiro ano, Zuma já estava mostrando uma preferência pelas soluções não-confrontacionistas, acomodativas e mediadas para conflitos e guerras na África.

O governo Mbeki foi ativista na área da diplomacia para a paz, na reconstrução e no desenvolvimento pós-conflito. O novo governo se comprometeu a contribuir para a promoção da paz, segurança e estabilidade, entre outros meios, pela sustentação do envolvimento em operações de paz na África. Ele chegou a afirmar que a África do Sul ajudaria na reconstrução e no desenvolvimento do continente africano, especialmente em países em situação de pós-conflito, como República Democrática do Congo, Sudão, Burundi, Saara Ocidental e Zimbábue. Mas como e onde este foco se sustentaria?

Aqui poderia haver evidência de uma ruptura entre a política dos dois presidentes. Começando com as questões bilaterais, mais especificamente a escolha de Zuma por Angola como destino para sua primeira visita de Estado, realizada em agosto de 2009. Na ocasião o presidente foi acompanhado por 11 Ministros de gabinete, altos funcionários do governo e a maior delegação empresarial a acompanhar uma visita oficial de um Chefe de Estado sul-africano desde 1994. Zuma estava determinado a restabelecer a solidariedade com Angola, um país com o qual as relações tinham sido severamente tensionadas durante os anos Mbeki. Angola não gostava do status hegemônico da África do Sul na região, e o presidente angolano, José Eduardo dos Santos, nunca respondeu positivamente às iniciativas de Mbeki em direção a relações mais estreitas. Ao longo de quase uma década de seu governo, Mbeki falhou em sua tentativa de garantir uma visita oficial de seu homólogo angolano à África do Sul. Em 2007, o relatório Browse Mole Intelligence Report foi vazado pela agência de combate ao crime organizado da República, os 'Escorpiões' (Scorpions), contendo alegações graves contra o presidente angolano e acusando-o de ter apoiado um complô para derrubar Mbeki, fornecendo apoio financeiro e político para a campanha do vice-presidente do CNA Jacob Zuma para substituí-lo como chefe de Estado (Mail \& Guardian Online, 2009). O relatório de inteligência sugeriu que Angola estava descontente com o papel preeminente que Mbeki passou a desempenhar na diplomacia africana, e que os angolanos eram favoráveis a uma estratégia na qual o papel dele seria reduzido. 
Tendo como pano de fundo essas acusações e um gélido relacionamento entre Luanda e Pretória-Tshwane, não foi de estranhar que Zuma tenha escolhido Angola como seu primeiro destino para uma visita oficial após tornar-se chefe de Estado. Em uma postura positiva, a ideia de elevar os laços entre África do Sul e Angola a um plano mais estratégico soou como uma medida positiva, e certamente havia benefícios bilaterais a serem alcançados economicamente. Em um nível mais sutil, surgiu a questão de saber se a restauração dos laços sinalizou uma mudança geocontinental na política, que se distanciaria dos gostos de Nigéria, Argélia, Etiópia, Tanzânia e Gana. Caso negativo, não está claro como África do Sul e Angola esperam alcançar a meta estabelecida, que surgiu durante a Cúpula, de os dois países desempenharem um papel estratégico sub-regional e continental. No caso de Angola seria curiosa uma escolha por desempenhar esse papel. Enquanto Luanda abriga um desejo de ser reconhecida como um hegêmona regional, e busca o status e o prestígio do rótulo, é menos claro se o país tem um plano sub-regional e continental, muito menos a vontade para executá-lo.

A escolha de Zuma de ungir Angola como o parceiro estratégico africano número um da República teve sérias implicações para a, até então, mais forte relação bilateral africana na história do pós-Apartheid. Entre 2009 e 2012 observou-se um declínio acentuado na relação entre Pretória e Abuja, com esta última sentindo-se abandonada pela África do Sul e as tensões no relacionamento vindo à tona durante a guerra da Organização do Tratado do Atlântico Norte (OTAN) contra a Líbia em 2011. O voto sul-africano na questão da Líbia foi contra as aparentes proposições fundamentais sobre a política externa da África do Sul, incluindo soluções pacíficas de controvérsias; soluções africanas para problemas africanos; defesa da soberania dos Estados Africanos; e defesa do multilateralismo e da centralidade das Nações Unidas (Landsberg \& Moore, 2011, p.72). Embora tenha sido a UA que em 2010 nomeou a África do Sul para retornar ao Conselho de Segurança como membro nãopermanente de janeiro de 2011 a dezembro de 2012 - quase dois anos após ter terminado a sua primeira passagem pelo órgão, de janeiro de 2007 a dezembro de 2008 - o governo Zuma, juntamente com a Nigéria e Gabão, votou a favor das resoluções da Líbia em aparente isolamento da UA (Landsberg \& Moore, 2011, p.73). A África do Sul também realizou o seu voto sem consultar os seus novos parceiros do BRICS (Brasil, Rússia, Índia, China), para o desgosto de alguns deles, como China e a Rússia.

Como consequência parcial da tempestade sobre a Líbia, "a África do Sul e a Nigéria, além de não estarem se relacionando bem”, argumentou Patrick Smith, "vão se amarrado com suas próprias confusões políticas" (Relatório da África, Fevereiro de 2012, Editorial). Esta foi uma situação lamentável. Deve-se lembrar 
que entre 1999 e 2008, África do Sul e Nigéria construíram uma das mais fortes parcerias estratégicas no continente africano, estabelecida para "facilitar o fortalecimento da cooperação existente ... em questões de paz, segurança e estabilidade" (citado em Landsberg, em Adebajo \& Mustapha, 2008, p.204). A relação bilateral e multilateral entre os dois países foi de importância estratégica, na medida em que ambos ajudaram a construir a UA e engendrar o NEPAD. Ambos os países moldaram a UA de forma distanciada dos planos de Muammar Gaddafi dos Estados Unidos da África (USAf), como uma ideia de união de Estados e sob a liderança de Mbeki e Obasanjo. Os dois Estados africanos pivôs embarcaram em um concerto real de diplomacia "no interesse da renovação africana, tentando assumir a responsabilidade primária de gestão dos assuntos inter e extra-africano" (citado em Landsberg, em Adebajo \& Mustapha, 2008, p.204).

Pretoria-Tshwane e Abuja acordaram em "manter e aumentar, se necessário, a frequência e a regularidade das consultas entre os dois países sobre questões de interesse multilateral, internacional e regional". Os dois países consideraram o seu relacionamento como "... de importância estratégica, particularmente à luz da promoção do desenvolvimento e da promoção do NEPAD ... assim como a evolução dos mecanismos em torno da UA" (Landsberg, em Adebajo \& Mustapha, 2008, p 0,204). Desde os desagradáveis acontecimentos dos votos da Líbia em 2011, houve um esfriamento na relação entre Nigéria e África do Sul, a tal ponto que no final de 2011 e início de 2012 houve um efetivo congelamento no relacionamento. De acordo com Adekeye Adebajo, “a diplomacia desajeitada da África do Sul nas questões da Costa do Marfim e da Líbia [resultou] no esfriamento de relações com seu anteriormente próximo parceiro estratégico, a Nigéria" (Adebajo, 9 de Fevereiro de 2012). Patrick Matlou do Africa Institute of South Africa argumentou que, "o que deveria ser uma parceria estratégica está cada vez mais ficando atolada em diferenças entre os dois países, amplamente vistas nas formas de engajamento dos seus governos". Ele nos lembra que "não houve comemorações da [comissão] binacional em 2010 e 2011" e que "África do Sul e Nigéria são muitas vezes vistas e atuam como rivais". Há pouca dúvida de que uma das relações bilaterais mais estratégicas e importantes do continente se degenerou para tensas relações nos últimos anos. A Nigéria se vê como o gigante, "como maior e possuidora de mais recursos" e um "um líder de longa data na África". Acreditam que foram "os campeões da luta anti-Apartheid e que a África do Sul deve mostrar agradecimento pela assistência que desempenharam na sua transformação. A África do Sul, segundo a expectativa de Abuja, deve "ficar em segundo plano em relação à Nigéria", e, ao mesmo tempo, de acordo com Matlou, "tem por meio da força do exemplo, a clareza de suas relações internacionais e políticas, e através do papel de liderança agraciado a ela, e é frequentemente convidada a liderar, até mesmo onde ela está relutante" 
(ASIA Focus, Nov / Dez 2011, p.3). E há ainda a rivalidade em relação ao assento no Conselho de Segurança da ONU.

Há pouca dúvida de que uma das mais estratégicas e importantes relações bilaterais do continente se degenerou nos últimos anos em direção a uma interação tensa. Enquanto que durante os anos de Mbeki e Obasanjo houve tensões os dois líderes garantiram a sua administração e preservaram as relações no nível de um “concerto de potências". Desde 2009, no entanto, o relacionamento se deteriorou a tal ponto que os dois Estados estão mal se falando. Em um recente boletim político, o Centre for Conflict Resolution recomendou que "as relações entre África do Sul e Nigéria - os dois principais hegêmonas regionais na África subsaariana - devem ser urgentemente melhoradas para proporcionar uma liderança para reunir uma frente diplomática africana na ONU e em outros fóruns diplomáticos internacionais" (CCR, 2012 , p.5). Muitos sentiram que era imperativo que estes Estados africanos pivôs assumissem a liderança na restauração da eficiência e eficácia na UA e nas demais organizações continentais.

Embora tenha havido diversas promessas de que Zuma adotaria uma postura confrontacionista mais dura em direção a Mugabe e ao Zimbábue, é menos provável que haja uma mudança da abordagem tradicional, que, para além de um compromisso explícito de trabalhar para uma eleição livre e justa o mais breve possível, parece evocar os negócios (ou a falta deles) como ponto crucial para Tshwane-Pretória. Zuma disse que iria trabalhar com todas as partes no governo de unidade nacional do Zimbábue, a Zanu-Pf, MDC-Tsvangarai, e MDC-Mutambara, para tratar de "linhas de fratura potenciais" dentro do governo inclusivo, para resolver suas diferenças e para assegurar que este governo trabalhe mais efetivamente (Diretor-Geral Ayanda Ntsuluba, 2009). Isso inclui resolver as diferenças sobre questões como os cargos de Governador do Banco Central e de Procurador-Geral (Diretor-Geral Ayanda Ntsaluba, 2009). No entanto, o Governo da Unidade Nacional (GNU) é frágil e as três partes envolvidas no pacto são relutantes. É provável que o GNU passe por muitos ajustes e retomadas, e há ainda uma chance de ocorrer uma ocasional evasão de alguma das partes, especialmente as duas facções do MDC. A África do Sul disse que iria trabalhar com as potências ocidentais como a União Europeia e outros parceiros para reengajar o Zimbábue, mas como Mugabe continua com o seu declínio à senilidade e com acessos cada vez mais bizarros, a questão pertinente é quem é o mais distante da realidade, ele ou Zuma?

No que diz respeito à República Democrática do Congo (RDC), o governo de Zuma continua utilizando o veículo criado pelo governo Mbeki para comprometer o país centro-africano com a gestão de seus conflitos civis pós-coloniais, a saber, a Comissão Binacional RDC-África do Sul (Diretor-geral Ayanda Ntsaluba, 2009). Ao 
se comprometer com a RDC, a África do Sul se concentraria na análise do progresso na implementação de projetos e em questões-chave relacionadas com a reconstrução e o desenvolvimento pós-conflito, em particular, ajudando a RDC a construir a capacidade de suas forças policiais e de segurança e a edificar as instituições do Estado para governar de forma mais efetiva. Enquanto que o governo de Mbeki ajudou a intermediar uma aproximação entre Ruanda e Burundi, Zuma escolheu assumir este papel e enfatizar a necessidade de os dois países melhorarem a situação de frágil segurança entre eles.

O Sudão é outro país e desafio sobre o qual a África do Sul tem investido muito capital político na tentativa de resolver questões políticas e de segurança. Ao passo que Mbeki tomou um interesse particular no Sudão e engajou-se regularmente na diplomacia pessoal, Zuma parece preferir uma abordagem mais secundária e delegar consultas em torno da questão à sua Ministra das Relações Internacionais e Cooperação. $O$ governo Zuma adotou uma visão de que a unidade entre o Norte e o Sul permanecia frágil e que a autodeterminação para que o recém-formado Sudão Sul poderia desenterrar mais tensões e divisões entre o Norte e o Sul, ao invés de cimentar unidade e solidariedade. A Ministra das Relações Internacionais confirmou que a África do Sul deu "uma importante contribuição para encontrar uma paz duradoura no Sudão quando presidiu a Comissão Ministerial de Reconstrução Pósconflito no país" (Nkoana-Mashabane, 2009a). Ela confirmou que as tropas sulafricanas foram um componente importante da presença da UA e da ONU na manutenção da paz em Darfur e que "o ex-presidente Thabo Mbeki está liderando um painel de alto nível da União Africana, cujo trabalho deverá nos ajudar a enfrentar os desafios da justiça e de reconciliação naquele país" (NkoanaMashabane, 2009a).

Uma área em que o governo Zuma não buscou disfarçar a sua política de continuidade com relação à linha de Mbeki foi a preferência para negociar a favor de governos inclusivos no continente. Por exemplo, apoiou o trabalho do ex-presidente de Moçambique Joachim Chisano como mediador nomeado pela SADC para tentar resolver a crise em Madagascar, que foi caracterizada pela SADC e pela UA como um exemplo de "mudança inconstitucional de governo" (Nkoana-Mashabane, 2009a). Prática essa que tem sido rejeitada por estas instituições continentais. Decidida a reverter a prática inconstitucional e a restaurar a ordem em Madagascar, PretoriaTshwane saiu em defesa do movimento de Chissano em favor de um governo inclusivo que veria Ravalomanana como presidente, e o personagem que o expulsou, Rajoelina, como participante de tal governo (Nkoana -Mashabane, 2009a). Ambos seriam autorizados a participar de uma nova corrida presidencial após o período de transição. 
Na realidade, houve indícios de associação e dissociação de Zuma com a política estrangeira de Mbeki. Seja no papel ou na teoria, a posição do governo Zuma para a resolução de conflitos na África era, portanto, muito em linha com a preferência da administração de Mbeki por soluções inclusivas e negociadas, e apresentou um notável grau de continuidade com a abordagem do governo anterior. Mais uma vez, qualquer postura de mudança e ruptura em relação à abordagem do governo de Mbeki para resolução de conflitos não resiste a um exame minucioso. Na realidade a nova administração optou por se construir sobre a abordagem do governo antecessor. Além disso, há ainda sinais de que a pretensão retórica de procurar a mudança é, em alguns casos, ignorada completamente, e a continuidade passa a ser aparentemente aceita como norma. No que concerne a Zuma, ele procurou a oportunidade política, permitindo alguns a acreditar que modificaria a agenda de Mbeki, enquanto sabia muito bem que teria que principalmente se ater a essa agenda que ele mesmo ajudou a moldar durante 1999-2005.

\section{Melhorar a Integração Política e Econômica da SADC}

Agora, é pertinente considerar as estratégias planejadas da África do Sul para melhorar a integração política e econômica da SADC, o que se relaciona com a priorização pelo novo governo das Comunidades Econômicas Regionais (CERs), as quais atuam como pilares institucionais da união continental. Como a Ministra da Cooperação Internacional colocou, a política é "informada pelo nosso compromisso de contribuir para a transformação e o realinhamento da SADC, de uma organização regional preocupada principalmente em uma agenda política para uma Comunidade Econômica Regional (CER), que irá atender os desafios da globalização"(NkoanaMashabane, 2009a).

Assim como na integração regional e no papel da SADC em questões relativas à paz e à segurança, e destacando-se a governança como prioridade, o governo Zuma prometeu se concentrar em fazer uma contribuição para a coesão política e o fortalecimento da governança e da capacidade da SADC, incluindo o estabelecimento de pessoal em posições estratégicas dentro do Secretariado. É importante ressaltar aqui que esse foco sobre a coesão regional dado pela administração de Zuma não é novo; tem sido uma questão perturbadora da política externa desde o fim do Apartheid, sobretudo, a lacuna existente entre intenções e capacidade. Não obstante a imponente promessa elevada dada pelo governo, a África do Sul continua sendo um dos países africanos mais sub-representados em fóruns internacionais multilaterais, com sérias implicações para os objetivos relacionados ao núcleo do seu interesse nacional e à política externa. Por um lado, o país promete promover a integração 
regional, nomeadamente através de protocolos da SADC, que visa melhorar a segurança e a estabilidade, a infraestrutura, os transportes (terrestre, aéreo e marítimo), a administração pública e outros setores, a coordenação de planos multisetoriais, e a harmonização de políticas industriais. Por outro lado, enquanto é sabido que existe uma política de destacamento internacional sobre a mesa, o status prático dessa política permanece obscuro.

O governo Zuma declarou também que avançará para uma maior integração econômica regional e debaterá as fontes de desacordo entre os membros da União Aduaneira da África Austral ${ }^{10}$ (SACU) sobre questões como a política comercial e receitas. Questiona-se, entretanto, se a nova administração planeja continuar com o paradigma político inovador do governo de Mbeki, apresentado nos últimos anos da administração anterior, nomeadamente o da integração regional de desenvolvimento. O que de fato está indicado é que o governo de Zuma estará se movendo para uma integração regional econômica aprimorada e tratará das fontes de desacordo entre os membros da SACU sobre questões como a política comercial e a partilha de receitas.

O mais próximo de uma ideia explícita de desenvolvimento encontra-se na política declarada do governo para os Acordos de Parceria Econômica (EPAs), articulada no Quadro Estratégico de Médio Prazo ${ }^{11}$ (MTSF) de 2009, onde a ideia sugerida foi que a África do Sul procure garantir que os EPAs tenham uma agenda de desenvolvimento e apóiem a integração regional. No entanto, continua existindo uma grande diferença entre os países membros da SADC sobre como responder aos EPAs, com alguns estando apreensivos sobre a adoção desta plataforma e outros a vendo como um gatilho importante para o desenvolvimento. De qualquer maneira, são necessárias posições comuns da SADC sobre os EPAs e outros instrumentos comerciais. Foi compreensível, portanto, quando a Ministra das Relações Internacionais declarou que a África do Sul deve "continuar a refletir sobre os desafios em relação à nossa interação com os países da SADC, em particular nossas diferentes posições sobre as negociações em torno dos EPAs com a UE" (NkoanaMashabane, 2009a ). Há, portanto, a necessidade de analisar as implicações dos EPAs sobre o programa de integração regional da SADC.

O governo Zuma também está às voltas com a questão da colocação em funcionamento do Fundo de Desenvolvimento de Preparação de Projetos ${ }^{12}$ (PPDF), como o primeiro passo para o Fundo de Desenvolvimento da SADC. Este plano coincide com a crise financeira global e as dificuldades dos doadores honrarem seus

\footnotetext{
10 Southern African Customs Union.

11 Medium Term Strategic Framework.

12 Project Preparation Development Fund.
} 
compromissos para os Estados-membros da SADC, algo que tem sido um duro golpe para a região. As perguntas surgem sobre se a África do Sul vai tomar a iniciativa de envolver a fraternidade dos doadores para assegurar que cumpram as obrigações e transformem as promessas em desembolsos. E sobre a relação entre o Fundo da SADC e a SADPA? Quais são os planos da África do Sul para reforçar esse fundo? Uma pergunta ainda mais importante no contexto deste trabalho é se o governo Zuma vai ser mais eficaz na execução de seu mandato regional declarado, ou se estamos propensos a ver hesitação do governo, o que resultaria na aplicação deficiente das metas estabelecidas?

\section{Fortalecimento da Cooperação Sul-Sul}

O terceiro pilar da política externa a ser considerado pela administração de Zuma é, segundo o MTSF de 2009, o “fortalecimento das relações Sul-Sul”. O primeiro ponto a ser notado é que há um grande grau de continuidade em relação à administração de Mbeki de "consolidação da agenda do Sul" através da cooperação Sul-Sul. A principal lógica sustentando as estratégias de cooperação Sul-Sul do governo de Zuma seria "garantir a criação de esferas políticas, econômicas e sociais necessárias para a luta contra a pobreza, o subdesenvolvimento e a marginalização do Sul". Novamente, a Ministra Nkoana-Mashabane admitiu estar seguindo Mbeki quando salientou que "a África do Sul continuará a construir relações baseadas na solidariedade e na cooperação com grupos regionais e sub-regionais do Sul tais como o Movimento dos Não-Alinhados (MNA), o Fórum para Cooperação China-África (FOCAC), o Fórum África-Índia, o G77 mais a China e a Nova Parceria Estratégica África-Ásia (NAASP) em busca da consolidação da Agenda Africana". O MTSF de 2009 declarou que o foco das estratégias de "cooperação Sul-Sul" seria (MTSF, 2009):

1. Continuar o compromisso com organizações do Sul, como o Movimento dos Não-Alinhados (MNA), o G77 mais a China, e outros.

2. Implementar e monitorar os Planos de Ação e o Fórum de Acordos Trilaterais entre a Índia-Brasil-África do Sul (IBAS), bem como assegurar que acordos setoriais alcancem resultados tangíveis que cheguem e beneficiem os cidadãos de todos os três países.

3. Revitalizar a Nova Parceria Estratégica África-Ásia (NAASP) como um veículo relevante para a cooperação Sul-Sul e esforçar-se para garantir que os desafios de implementação dos projetos estabelecidos na Conferência Afro-Asiática em 2005 sejam debatidos. 
4. Empenhar-se e apoiar os esforços da União Africana e das Nações Unidas (ONU) em encontrar uma solução douradora para situações de conflitos no continente africano, assim como em conflitos em qualquer lugar, incluindo o conflito Israel-Palestina.

Na esfera da cooperação Sul-Sul, há um evidente ethos de continuidade entre as posições políticas emergentes do governo Zuma e aquelas adotadas pela administração de Mbeki. Importa lembrar que os fóruns do Sul que o governo Zuma escolheu priorizar foram os mesmos em que o governo Mbeki desempenhou um papel central na revitalização e no fortalecimento, incluindo o IBAS, a NAASP, o MNA e o G77 mais a China (C. Landsberg, 2010, pp. 227-228). De fato, a nova administração já não tinha a intenção de negar os fortes laços políticos e econômicos que Mbeki cultivou com a Índia, Brasil e China, ao prover oportunidades de diversificar as relações internacionais, especialmente na esfera política.

Mesmo que desejasse cumprir a sua promessa de romper com o passado, a administração rapidamente descobriu que, na frente Sul-Sul pelo menos, o governo de Mbeki definiu e consolidou a política externa à medida que havia pouco espaço para manobras. Assim não houve alternativa a não ser optar por continuar e focar na implementação e na operacionalização dessas direções e decisões políticas. O que é preciso agora é transferir a atenção nessas organizações e programas para a implementação de políticas e para garantir que se cumpram as metas imponentes estabelecidas. Os desafios nesse caso não deviam ser subestimados. Jacob Zuma assumiu as rédeas da política em um momento em que muitos companheiros Chefes de Estado da América Latina, do Caribe e da Ásia estavam começando a se desengajar de muitos desses processos. Um grande fardo cairá nos ombros da África do Sul caso tente resgatar e ressuscitar algumas dessas iniciativas, e o governo enfrenta enormes desafios na frente interna, que podem vir a obrigar o Presidente e seus Ministros a reduzirem o aventurismo na política externa e a focar nas prioridades internas. Isso pode significar que iniciativas como o IBAS e NAASP tenham de ser negligenciadas.

Novamente, houve continuidade entre as estratégias das duas administrações, mas o exame da prática e a implementação efetiva da política externa mostra poucos sinais que a sustentação ou o asseguramento da sobrevivência desses fóruns continuam sendo uma prioridade chave no governo de Zuma. É então a lacuna políticas-e-implementação, promovida pelo fracionalismo na aliança governante bem como pelas tensões no governo, que temos de olhar quando se trata do governo Zuma. Basta ressaltar que Zuma herdou de seu antecessor uma estratégia Sul-Sul muito bem definida e não havia necessidade de reinventar a roda; o foco deveria estar na implementação. 


\section{Relações Estratégicas com o Norte}

Envolver as potências industrializadas do norte e suas associações é o quarto pilar da política externa da nova administração de Zuma, e nesse sentido é possível ver novamente sinais de associação e dissociação em relação às políticas de Mbeki. A lógica por trás de uma estratégia para continuar a envolver as potências industrializadas foi apresentada quando a Ministra de Relações Internacionais e Cooperação declarou que os "países do Norte são inegavelmente um poder econômico estabelecido no mundo e continuam sendo essenciais para o bem-estar econômico do mundo em desenvolvimento". Dadas essas considerações econômicas, a África do Sul priorizou "o estabelecimento de parcerias com estes países no contexto do comércio, desenvolvimento e cooperação". O engajamento em direção ao Norte, afirmou-se, seria ainda feito para avançar a agenda de desenvolvimento da África do Sul, do continente e do resto do Sul. Em médio prazo, a política em relação ao Norte veria o governo Zuma continuar buscando uma abordagem para a região, particularmente a OCDE e o G8, orientada para o desenvolvimento e o investimento, bem como continuar a trabalhar para a consolidação da Agenda Africana através da implementação dos programas do NEPAD relevantes em todos os compromissos dessa natureza.

A visita em agosto de 2009 pela Secretária de Estado norte-americana Hillary Clinton confirmou o desejo da África do Sul de consolidar laços estreitos com Washington e as relações econômicas estratégicas em particular, desejando tirar "o máximo proveito do Ato de Crescimento e Oportunidade EUA-África ${ }^{13}$ (AGOA)", e neste aspecto pode-se dizer que Zuma foi mais ambicioso do que seu antecessor. Deve ser lembrado que, durante as eras presidenciais de Mbeki e George W. Bush na África do Sul e nos EUA, respectivamente, a relação bilateral entre os dois países esfriou significativamente devido a diferenças acerca da conduta unilateral global dos EUA e da invasão ilegal do Iraque liderada pelos Estados Unidos em 2003. Por outro lado, houve irritação americana devido à abordagem "silenciosa" da África do Sul para a crise no Zimbábue. O governo Zuma esteve comprometido a fortalecer-se para reconstruir essa relação e extrair o máximo de benefícios econômicos da superpotência mundial. A guerra da OTAN com a Líbia em 2011 levou a respostas furiosas de Pretoria-Tshwane, e a relação com o P-3 do Conselho de Segurança da ONU, França, Grã-Bretanha e os EUA, se deteriorou rapidamente.

Chegando à União Europeia, por outro lado, houve uma continuidade entre os governos Mbeki e Zuma, com ambos os presidentes determinados a reforçar as

${ }^{13}$ US Africa Growth and Opportunity Act. 
relações com os parceiros líderes em comércio com a África do Sul e transformar essa realidade em benefícios para si e para o continente Africano. A África do Sul comprometeu-se em avançar as relações UE-UA, colocando em prática o processo de implementação do Primeiro Plano de Ação UE-África. Nesse caso a administração Zuma arrancou uma folha do livro de seu antecessor, que tinha aprendido algumas lições difíceis das negociações do Acordo de Comércio, Desenvolvimento e Cooperação ${ }^{14}$ (TDCA) com a Europa, acima de tudo em não atuar de forma solitária. Assim, à medida que o governo considera a mentalidade UE-África, teria que levar em conta outros africanos e os seus medos.

Comparando a política geral de Zuma vis-à-vis o Norte, há uma semelhança geral na política, notavelmente no engajamento com o intuito de extrair compromissos para o desenvolvimento das prioridades Africanas e do Sul. Sob o mantra do "interesse nacional", os dois líderes procuraram avançar as agendas da África e da ampla comunidade para o desenvolvimento. Zuma tentou atingir um vínculo mais positivo com os americanos, mas a relação azedou na sequência dos abusos por parte dos EUA e da OTAN das resoluções 1970 e 1973 do Conselho de Segurança da ONU (CSNU), referentes ao conflito na Líbia em 2011, resoluções para as quais a África do Sul votou a favor. Quando a OTAN transformou um mandato de estabelecimento de uma zona de exclusão aérea (res. 1973) em uma agenda de mudança de regime houve grandes danos no relacionamento. $\mathrm{O}$ quão bem-sucedido será Zuma em firmar estreitas relações com as potências do Norte, ao mesmo tempo em que também introduz um elemento de independência vis-à-vis essas potências, é difícil de determinar.

\section{A Participação no Sistema Global de Governança}

O quinto pilar do governo Zuma envolvendo a política externa é o de "participação no sistema global de governança", muito semelhante às "estratégias de governança global" da administração de Mbeki. Na parte inicial deste texto, ao lidar com as estratégias de política externa do governo Mbeki, eu argumentei que o governo sul-africano, de 1999 a 2008, seguiu essencialmente uma política externa transformacional e o desenvolvimentista. Isso foi especialmente verdadeiro em relação às estratégias de governança global do governo Mbeki, uma dimensão da diplomacia que Zuma tomou emprestada assim que ele e o seu governo sustentaram as noções de transformação e desenvolvimentismo em sua política externa.

\footnotetext{
14 Trade, Development and Cooperation Agreement.
} 
Novamente, a questão aqui é que, no papel, revelou-se a continuidade entre a política externa do novo governo frente à do seu antecessor. As descontinuidades e dissociações aconteceram na prática.

A Ministra de Relações Internacionais e Cooperação declarou logo após as pesquisas de abril de 2009:

\begin{abstract}
Acreditamos que a transformação do sistema internacional não apenas dará à África uma grande voz, mas nos colocará em uma melhor posição para lidar com a condição de desenvolvimento do nosso continente. Continuaremos a trabalhar com outras nações e atores não-estatais progressistas para a reforma das Nações Unidas, incluindo as instituições de Bretton Woods. Nós não podemos alcançar os nossos objetivos de um mundo melhor enquanto as configurações atuais do Conselho de Segurança da ONU são informadas pelas preocupações de geopolítica e segurança dos anos 1950, quando grande parte da África estava sob o domínio colonial (Nkoana-Mashabane, 2009a).
\end{abstract}

As aspirações de transformação do governo tais como as aqui articuladas miravam reformas e transformações de instituições políticas e financeiras globais. Ao validar a ideia de uma política externa desenvolvimentista, o MTSF em 2009 declarou que, nas "relações estratégicas com o Norte", as estratégias de Zuma para o "sistema de governança global" estavam orientadas para garantir "que os objetivos desenvolvimentistas do mundo em desenvolvimento fossem debatidos". Este alvo seria atingido através de seis sub-objetivos (MTSF, 2009):

1. Participação ativa nos processos de reforma econômica global por meio do engajamento contínuo com as instituições econômicas e financeiras internacionais e regionais, tais como bancos multilaterais de desenvolvimento, o FMI e o G20.

2. Garantir que a dinâmica atual dentro do G20 seja mantida e que não se concentre apenas nos esforços para mitigar a crise global, mas também para chegar a um acordo sobre as reformas de governança nas instituições de Bretton Woods.

3. Utilizar os grupos e as alianças de negociação existentes para alcançar objetivos de países em desenvolvimento.

4. Trabalhar com países de mesma mentalidade na formação de um movimento coletivo para a transformação da governança global

5. Desempenhar um papel ativo no âmbito da OMC no sentido de garantir a conclusão das negociações da Rodada de Desenvolvimento de Doha e lutar pelos objetivos comuns com os parceiros que compartilham a mesma opinião.

6. Continuar a participação ativa no seio das instituições de governança global em assuntos políticos, econômicos e de segurança, incluindo a reforma das Nações Unidas, o desenvolvimento sustentável e o desarmamento. 
Aqui também não se viu muita novidade. Vale lembrar que o governo Mbeki havia buscado uma dupla estratégia de governança global, uma destinada a questões político-securitárias e a outra focada no desenvolvimento socioeconômico. Embora o governo Zuma não tenha estabelecido uma distinção específica entre estratégias político-securitárias e de desenvolvimento, torna-se claro que as estratégias emergentes de governança global enfatizaram, na prática, ambas as dimensões. De fato, Mbeki colocou grande ênfase em desempenhar um "papel proeminente nos assuntos globais" e, numa "forma ativa e proposital [, em perseguir] os seus interesses na ONU" (DFA, 2005, p.20). Para o ex-chefe de Estado, isso dizia respeito ao uso injusto de poder pelas potências ocidentais e outras dentro das Nações Unidas e de outras instituições de governança global. A despeito do tropeço sul-africano no voto da Líbia e de sua perda de prestígio entre as fileiras do Ocidente, BRICS e África, o governo Zuma persistiu mantendo a reforma das Nações Unidas como uma prioridade-chave. Assim, a Ministra Nkoana-Mashabane dedicou-se a “... assegurar que a $\mathrm{ONU}$ continue sendo central para tratar da paz global e questões de segurança. Enquanto estamos no Conselho de Segurança como membros não-permanentes", ela afirmou, "ficamos preocupados que nós estamos lá como cidadãos de segunda classe, quando deveríamos ser todos representados igualmente na ONU". Ela ressaltou aos seus colegas do IBAS que “... o momento é oportuno, dada a nossa representação conjunta no Conselho de Segurança, para avançar de forma conclusiva na reforma do Conselho de Segurança da ONU (CSNU)". A Ministra não limitou suas observações à ONU e ao CSNU, também ofereceu recomendações a outras instituições multilaterais: "Em questões de comércio internacional", opinou a Ministra, "a conclusão da Rodada de Desenvolvimento de Doha da OMC tem levado tempo demais e é tempo de darmos uma finalidade, mas isso certamente não será feito ao custo de alcançar um resultado equilibrado para os países em desenvolvimento" (Nkoana-Mashabane, 08 de março de 2011). Tal como acontece com Mbeki, o governo de Zuma se comportou como porta-voz para o Sul em desenvolvimento, pelo menos, como manifestado na política.

As semelhanças entre o que os governos de Zuma e Mbeki, pelo menos no papel, eram palpáveis, mas foi na prática que nós testemunhamos as divergências. Diferenças acentuadas surgiram, por exemplo, no comportamento das duas administrações nas votações no âmbito da ONU. Ao passo que o governo Mbeki adotou posições consistentes vis-à-vis questões controversas como o Irã, Zimbábue, Mianmar e outros, sempre se abstendo ou votando não, o governo Zuma, como dito anteriormente, demonstrou muita inconsistência em seu comportamento de voto em relação a questões como Líbia (resoluções 1970 e 1973) e Síria em 2011 e 2012. 
Marcados pela sua experiência sobre a votação relativa à Líbia e a interpretação seletiva da OTAN das resoluções 1970 e 1973, os representantes sulafricanos em Nova York optaram por se abster em uma votação crucial contra a Síria em outubro de 2011, afirmando que "estávamos preocupados que a resolução não deveria ser parte de uma agenda oculta para estabelecer novamente a mudança de um regime" (Sowetan Live, 6 de outubro de 2011). O porta-voz do DIRCO, Clayson Monyela foi mais longe e argumentou que "... estamos preocupados pois os patrocinadores dessa resolução rejeitaram uma a linguagem que claramente excluísse a intervenção militar na resolução da crise síria" (Sowetan Live, 06 de outubro de 2011).

Para além destes votos controversos no CSNU, a administração Zuma prometeu continuar a trabalhar para alcançar os Objetivos de Desenvolvimento do Milênio (ODMs), cuja concretização nos países africanos, de acordo com a MTSF 2009, a África do Sul continuará a defender. Nesse ponto a África do Sul enfatizou uma estratégia de vinculação que sugeriu que "democracia anda de mãos dadas com a justiça econômica e a prosperidade" e, como tal, era importante:

assegurar que a África permaneça No curso de sua busca para atingir os ODMs. A tática que o novo governo definiu para empregar é a de trabalhar com as forças progressistas do mundo para rogar à comunidade internacional para desempenhar um papel construtivo complementando os nossos esforços.

Ao participar de sua primeira Sessão Africana do G8 em Aquila na Itália em 2008, Zuma conclamou os países do G8 a se comprometerem em "apoiar os esforços africanos para promover a governança, o bom desenvolvimento e alcançar os ODMs". O problema até agora tem sido que os objetivos estabelecidos para perseguir essas estratégias de governança global, incluindo a promessa de garantir que os ODMs não caiam no esquecimento, ou assegurar que as questões de reforma da ONU não sejam varridas para debaixo do tapete, não foram acompanhados com a liderança prática. A África do Sul não mostrou a liderança necessária para forjar coalizões com outros Estados de mentalidade semelhante, de modo a assegurar que estas questões ficassem na dianteira, não manteve os pés das potências industrializadas presos a estas questões. Enquanto a África do Sul é único membro da África no G20, e até mesmo no Comitê de Desenvolvimento do G20, não tem usado a sua influência para garantir que o G20 venha ser um plano de desenvolvimento crível que atenda às necessidades especiais do continente ou de outros países em desenvolvimento. Novamente, o problema foi a falta de ação (Landsberg, "potências emergentes e o G-20, setembro de 2011). 
Muita coisa aconteceu desde que a África do Sul articulou esses objetivos. O país é agora um membro do Fórum Brasil-Rússia-Índia-China-África do Sul (BRICS), um bloco econômico de contestação nos assuntos mundiais. O BRICS ainda tem de esclarecer a sua agenda, tanto política quanto econômica, e as diferenças econômicas entre essas potências, sobretudo as desigualdades entre elas, poderiam se tornar uma fonte de tensão. Na verdade, esses países não só terão que resolver esta potencial fonte de conflito entre eles, mas eles também estão sob pressão para garantir que suas respectivas regiões se beneficiem de sua presença, ao contrário de se tornarem novas fontes de exploração e neoimperialismo na África e em outras regiões em desenvolvimento. A África do Sul já está sob pressão para garantir a representação dos interesses africanos de uma forma robusta e legítima dentro dos BRICS. De fato, a proposição de que os interesses da África do Sul estão em linha com os interesses africanos é contestada por muitos.

Devemos também lembrar que os dois membros dos BRICS, China e Rússia, são membros do Conselho de Segurança da ONU, e os outros três não são. Isso contribui para uma maior divergência ao invés de convergência entre os membros do BRICS, e faz-se necessário uma gestão cuidadosa das relações.

\section{O fortalecimento das relações políticas e econômicas}

As trajetórias de política externa da jovem administração de Jacob Zuma não se centraram apenas em dimensões e instituições multilaterais, mas também colocaram ênfase sobre a necessidade de reforçar as relações bilaterais políticas e econômicas. Aqui também teve seu curso influenciado pelas prioridades da política externa do governo de Mbeki, à medida que ele colocou grande ênfase na diplomacia econômica, e reforçou as relações econômicas com o maior número possível de Estados. Em seu discurso para a Conferência dos Chefes de Missões em agosto de 2009, a Ministra de Relações Internacionais lembrou os chefes de missões e aos diplomatas que:

Entre os nossos principais desafios na busca de nossos objetivos de política externa está o alinhamento e a coordenação da diplomacia econômica da África do Sul em todas as esferas de governo; o reforço das capacidades diplomáticas econômicas em nossas missões; e o incremento de esforços direcionados à melhoria da comercialização das marcas África do Sul e África no exterior (Nkoana-Mashabane, 2009a).

A política declarada estabeleceu que a estratégia da diplomacia econômica da África do Sul continuaria a se concentrar no fortalecimento das relações econômicas 
com os parceiros econômicos tradicionais; na ampliação das relações comerciais com os mercados emergentes na Ásia, América Latina e Europa Oriental; e na promoção do comércio intra-africano, de modo a incrementar o desenvolvimento econômico no continente.

As dimensões de política externa do MTSF 2009 identificaram como vital o objetivo de "reforço das relações políticas e econômicas", em particular, reforçar a "diplomacia econômica", e o foco seria em nove pontos nodais (MTSF, 2009):

(1) Promoção e expansão de parcerias bilaterais que visem à promoção dos interesses econômicos da África do Sul através de mecanismos estruturados;

(2) Continuar a se concentrar na consolidação das relações econômicas com os parceiros econômicos tradicionais e estabelecidos;

(3) Ampliar as relações comerciais com os mercados emergentes na Ásia, no Oriente Médio, na América do Sul, na Europa Oriental, bem como a promoção do comércio intra-africano com o intuito de reforçar o desenvolvimento econômico na África;

(4) Fortalecer a cooperação entre povos através de organizações da sociedade civil e de outras partes interessadas;

(5) Garantir que haja alinhamento e coordenação dos compromissos internacionais da África do Sul entre todas as esferas de governo e entre os setores público e privado;

(6) Fortalecer a capacidade diplomática econômica em missões sul-africanas no exterior, através da formação eficaz e intensa para todos os representantes;

(7) Continuar a envolver a China na finalização da Parceria para o Crescimento e Desenvolvimento (PGD);

(8) Melhorar os esforços destinados ao marketing da África do Sul e da África no exterior;

(9) Tratar das insuficiências identificadas na comunicação das posições sobre política externa da África do Sul, tanto na arena externa quanto na interna.

Este ênfase na diplomacia econômica veio sem nenhuma surpresa já que o novo governo estabeleceu desde o início que buscava acabar com o afastamento entre política interna e externa e introduzir estratégias que tornariam mais fácil para 
o DIRCO contribuir de forma mais eficaz para o alcance dos objetivos estratégicos nacionais identificados pelo governo.

Em outubro de 2009, o DIRCO lançou o seu tão esperado documento, o Quadro Conceitual para a Identificação dos Estados Âncora nas Cinco Regiões Geográficas Reconhecidas pela União Africana ${ }^{15}$ (DIRCO, Outubro 2009). Trata-se de uma declaração política em busca de "Estados-âncora", isto é, aqueles Estados que “... são influentes nas suas próprias regiões devido ao fato de que possuem fortes economias, grandes populações, amplo território, força militar, habilidade de projetar política externa, paz, segurança e estabilidade, e cujo colapso resultaria em um "caos transfronteiriço, mas cuja prosperidade e estabilidade reforçariam a vitalidade econômica da região". Esse documento alinha-se à ideia que "... os principais países [africanos] devem ter capacidade de atuar como catalisadores para o desenvolvimento, a boa governança, a paz e a segurança em suas respectivas regiões". Os "países âncora", continua o documento, "devem usar a sua influência para conduzir a agenda de desenvolvimento através da integração, coesão política, para consolidar a paz, segurança e estabilidade no continente" (DIRCO, outubro 2009, p.8).

\section{Conclusão}

No papel, houve muitas semelhanças e um elevado grau de associação entre os aspectos gerais da política externa dos governos Zuma e Mbeki. Na prática, porém, muitos desvios e dissociações surgiram e a política externa de Zuma mostrou muitos graus de dispersão e falta de foco. Enquanto o novo governo afirmou que o "interesse nacional" seria o cimento que daria coesão para a sua política externa, é menos claro como tais interesses vinculam-se com outras estruturas macro, tais como o Avanço Africano, a cooperação Sul-Sul, o diálogo Norte-Sul, a participação ativa no sistema global de governança, e o fortalecimento das relações políticas e econômicas. Há, portanto, uma necessidade de colocar os pontos nos is e os riscos nos ts para promover sinergia entre as várias vertentes da política externa. $O$ pressuposto que assume que essas diferentes estratégias de política externa possuem necessariamente coerência precisa de ponderação. A própria ideia do interesse nacional da África do Sul precisa ser enriquecida e até mesmo transformada em uma verdadeira doutrina que orientaria a política externa da República.

15 Conceptual Framework on Identification of Anchor States in the Five Geographical Regions Recognised by the African Union. 
Há um desafio igualmente grave enfrentado pela política externa do governo de Zuma, uma lacuna entre a política externa declarada no papel e as ações tomadas pelo governo na prática. Há então um gap entre política e operações que se revela na medida em que a política externa do governo Zuma é analisada. Em suma, enquanto o governo Zuma goza de uma política externa clara articulada no papel, na realidade, existe uma lacuna em duas vertentes que precisa urgentemente ser abordada: a lacuna entre os interesses nacionais declarados e os grandes estratagemas de política externa, e uma lacuna entre a política externa e as ações embarcadas pelo governo. Em última análise, a política externa de qualquer país é tão boa quanto for o seu resultado.

\section{REFERÊNCIAS}

Adekeye Adebajo, "SA made three key blunders in AU poll fiasco", Business Day, 9 February 2012.

Chris Landsberg, "South African foreign policy formulation, 1989-2010", in Albert Venter and Chris Landsberg (eds.), Government and Politics in South Africa, Fourth Edition, Van Schaik Publishers, 2011, pp. 231-256.

ASIA Focus, CEOs Corner, November-December 2011.

The Africa Report, No. 37, February 2012.

Centre for Conflict Resolution, South Africa, Africa, and the United Nations Security Council, Policy Brief 10, Somerset West, 13-14 December 2011.

Chris Landsberg, "Rising powers and the G20: A need for Leadership on Africa", The Stanley Foundation, Courier, http://www.stanleyfoundation.org/resources.cfrm?id=702\&article $=1$, accessed 21 March 2011.

Chris Landsberg and Candice Moore, "South Africa's Libya Vote: How is foreign policy decided?", In New Agenda, Issue 44, Fourth Quarter 2011, pp. 72-76.

Chris Landsberg, "Thabo Mbeki's Legacy of Transformational Diplomacy", in Daryl Glaser (eds.), Mbeki and After, Reflections on the Legacy of Thabo Mbeki, Wits University Press, 2010, pp. 209-241. 
Chris Landsberg, "An African 'concert of powers"? Nigeria and South Africa's construction of the AU and NEPAD", in Adekeye Adebajo and Abdul Raufu Mustapha (eds.), Gilliver's Troubles, Nigeria's Foreign Policy after the Cold War, UKZN Press, 2008.

Department of Foreign Affairs, Enhancing the African Renaissance and International Co-operation Fund (ARF), Presentation to the Foreign Service Institute, ARF Secretariat, 17 August 2008.

Department of International Relations and Co-operation (DIRCO), Conceptual Framework on Identification of Anchor States in the Five Geographical Regions Recognised by the African Union, Pretoria-Tshwane, October 2009.

Department of International Relations and Co-operation (DIRCO), Media briefing by the Director-General Dr. Ayanda Ntsaluba at the new International Relations and Co-operation Building, Pretoria-Tshwane, 13 October 2009.

Mail\&Guardian Online, "The Special Browse mole report: The veiled truth within", posted 5 may 2009.

Medium-Term Strategic Framework (MTSF), Guide to Government's Programme for the Electoral Mandate Period 2009-2014, Treasury, Pretoria-Tshwane, August 2009.

Minister Maite Nkoana-Mashabane, Opening Remarks by the Minister of International Relations and Co-operation, $7^{\text {th }}$ IBSA Tri-lateral Commission Meeting, New Delhi, 8 March 2011.

Minister Maite Nkoana-Mashabane, Speech by the Minister of International Relations and Co-operation, Heads of Mission Conference, 13 August 2009a.

Minister Maite Nkoana-Mashabane, Speech by the Minister during the Ministerial Outreach Programme, University of Limpopo, 16 October 2009b.

Minister Maite Nkoana-Mashabane, Address by the Minister of International Relations and Co-operation on the Occasion of the Gala Dinner with the Diplomatic Corps, Emperor's Palace, Kempton Park, 20 May 2009c.

Recebido em 23 de março de 2012. Aprovado em 30 de março de 2012.

*Este artigo foi traduzido por Gabriela Perin e revisado por Analúcia Danilevicz Pereira e Igor Castellano. 


\section{RESUMO}

Na tentativa de dar coerência e previsibilidade para a política externa da África do Sul, o governo de Jacob Zuma, desde que assumiu o cargo em maio de 2009, colocou ênfase no estabelecimento de relações com países e regiões, e outras questões e preocupações principais das relações internacionais. De acordo com a política, a procura do interesse nacional estava no centro das estratégias internacionais da República, com o "interesse nacional" sendo utilizado como um cimento para unir o edifício da política externa pós-governo de Mbeki. No papel, o governo parece ter ido longe em articular essa política externa ambiciosa, no entanto uma série de perguntas surgem. Essas políticas foram postas em prática e, se sim, elas seguem a agenda declarada ou existem graves desvios? Houve associação com as políticas de Mbeki no papel e uma dissociação de tais políticas na prática?

Como os vários princípios da política externa se relacionam com o epicentro do interesse nacional e com algum outro? Será que eles representam uma mudança acentuada na "Agenda Africana” do governo Mbeki ou são uma mera cópia? Este artigo procura responder a estas questões, em particular investigando se uma lacuna se desenvolveu entre a política pronunciada, ou expressa, e como ela foi posta em prática, através da sua implementação.

\section{PALAVRAS-CHAVE}

África do Sul; Jacob Zuma; Política Externa; 


\title{
COOPERAÇÃO SUL-SUL E A MUDANÇA DO PAPEL DOS ESTADOS DO GOLFO
}

\author{
Kristian Coates Ulrichsen ${ }^{l}$
}

Esse artigo avalia o papel dos estados membros do Conselho de Cooperação do Golfo (CCG) - Bahrein, Kuwait, Omã, Qatar, Arábia Saudita e Emirados Árabes Unidos - no âmbito da cooperação Sul-Sul. Ele traça as diferentes fases de engajamento entre os Estados do Golfo e outros países em desenvolvimento, e a mudança das dinâmicas que os sustentam.

Essas fases demonstram profundas mudanças que refletiram ajustes na formulação de políticas em resposta a catalisadores domésticos, regionais e internacionais. Quando analisadas em conjunto, as forças internas e externas que pressionam os Estados do CCG moldam a perspectiva de análise deste artigo. Além disso, essas pressões internas e externas moldaram as contribuições dos Estados do Golfo para a Cooperação Sul-Sul, e definiram os realinhamentos intra-regionais e internacionais nos quais o CCG se engajou.

A primeira parte do artigo examina as dinâmicas históricas profundamente acentuadas, que inicialmente limitavam as relações dos Estados do Golfo com o Sul global. Essas dinâmicas incluíam tendências conservadoras de seus sistemas de governo pós-tradicionais e o "mergulho" dos Estados do Golfo nas esferas de influência ocidentais, política e militarmente. Isso definiu a política internacional dos Estados do Golfo e isolou suas políticas de muitas forças que varreram o mundo em desenvolvimento durante as décadas de 1950 e 1960.

Esse período, contudo, testemunhou o início de interconexões transnacionais que ligavam os Estados do Golfo à outras nações em desenvolvimento, inicialmente através da prestação de assistência ao desenvolvimento no exterior e do patrocínio de organizações internacionais islâmicas. Nos anos 1980 e 1990, essas crescentes ligações transnacionais se tornaram interligadas com processos globalizantes extremamente rápidos. Contemporaneamente, o fim da Guerra Fria facilitou a

\footnotetext{
${ }^{1}$ Especialista em Kuwait, London School of Economics and Political Science. (austral@ufrgs.br)
} 
normalização com a China e com os estados pós-comunistas que migraram para economias de mercado.

Na segunda parte, o artigo avalia a ascensão dos Estados do CCG como atores globais significantes dos anos 2000 e mede os fatores estruturais responsáveis pela sua ascensão. Esse crescimento não só aprofundou e ampliou o papel dos Estados do CCG no contexto Sul-Sul, mas ocorreu em meio à dinâmica de mudança que reorganizaram as relações de poder ao redor do mundo e que posicionaram os Estados do Golfo para serem pivôs na mudança da ordem global. Coalizões de economias emergentes desafiaram e reformularam a arquitetura política e econômica da governança global. A crise econômica e financeira mundial, que alcançou o pico inicial em 2008-2009, impulsionou essas tendências e levou a realinhamentos significantes na governança financeira e energética.

Padrões recentes de cooperação fornecem uma clara indicação dos novos valores que os formuladores de políticas do CCG e suas elites adquiriram no Sul geográfico. Esses padrões recentes, os quais ainda complementam as relações políticas e securitárias com os EUA e os países europeus, são típicos da abordagem multifacetada de elaboração da política externa nos Estados do Golfo, que busca equilibrar as questões domésticas, regionais e internacionais ${ }^{2}$. As respostas dos Estados do Golfo ao início da Primavera Árabe refletem tanto os desafios quanto as oportunidades, com as tentativas da Arábia Saudita de implantar sua "generosidade financeira" para minimizar o impacto desestabilizador das transições regionais, enquanto o Qatar aproveitou a oportunidade para impulsionar suas credenciais como um ator internacional responsável, reunindo apoio árabe para a intervenção multinacional na Líbia.

Analiticamente, a terceira parte, que vai da diacrônica à temática, aborda as aplicações práticas das interações dos Estados do Golfo no contexto Sul-Sul. Essas aplicações incluem mudanças nos padrões de fluxos de comércio e investimento, modificando provisões para assistência ao desenvolvimento e mediação diplomática em ambientes afetados por conflitos, e uma reformulação das relações internacionais e da governança global num mundo onde o poder está crescentemente refratado através de diversos nós de influência.

\footnotetext{
2 Gerd Nonneman, "Determinants and Patterns of Saudi Foreign Policy: 'Omnibalancing' and 'Relative Autonomy' in Multiple Environments,", In: Saudi Arabia in the Balance: Political Economy, Society, Foreign Affair, eds. Paul Aarts and Gerd Nonneman. (London: Hurst \& Co., $2005), 315$.
} 
Coletivamente, essas mudanças revelam um reforço qualitativo e quantitativo das redes que ligam os Estados do Golfo ao Sul geográfico, e que operam bilateralmente nos níveis institucional, nacional e multilateral. Esses padrões de mudança têm implicações importantes para mudanças sem precedentes na ordem global vigente. A parte final explorará as trajetórias prováveis dos laços entre os Estados do Golfo e o Sul, bem como seus impactos em um ambiente internacional multipolar.

\section{Limitações de engajamento, 1945-1991}

As relações sociais e comerciais entre o Golfo e o resto do mundo remontam à antiguidade tardia e à era pré-islâmica. Uma densa rede de laços transoceânicos conectava os povos do Golfo a uma região mais ampla do Oceano Índico. Construtores navais e marinheiros locais construíram e navegaram seus navios (dhows e booms) que partiam do Golfo todos os anos para o subcontinente indiano e ao longo da costa leste da África. Tendências poderosas na migração e aculturação aumentaram esse fluxo e deram uma dimensão social particular ${ }^{3}$. Troca, comércio e liquidações formavam uma teia de interconexões que ligavam o comércio e as pessoas da região em comunidades maiores e sobrepostas. ${ }^{4}$

A mistura de povos e culturas influenciou o desenvolvimento de Estados e sociedades no Golfo. Essa história geográfica desmente qualquer noção da região como periférica na história mundial da era pré-petróleo, ou qualquer definição da região apenas pela sua posse de algumas das maiores reservas de energia do planeta. No entanto, a integração dos sheikhdoms da península árabe aos protetorados britânicos entre 1835 e 1916, influenciou fortemente o desenvolvimento político subsequente da região ${ }^{5}$. As entidades proto-estatais se emaranharam em uma unidade sub-regional orientada para dentro, para a qual a "proteção" britânica foi estendida em troca de relações políticas e econômicas exclusivas ${ }^{6}$.

\footnotetext{
${ }^{3}$ Lawrence Potter, The Persian Gulf in History (New York: Palgrave Macmillan, 2009), 10-11.

4 Thomas Metcalf, Imperial Connections: India in the Indian Ocean Arena (Berkeley: University of California Press, 2007), 9.

5 Após a assinatura do Tratado Geral, em 1820, e de uma Trégua Marítima, em 1835, o Império Britânico concluiu tratados individuais com os Trucial States (mais tarde Emirados Árabes Unidos) em 1835, Bahrain, em 1861, Kuwait, em 1899 e novamente em 1914, e Qatar, em 1916.

6 James Onley e Suleyman Khalaf. "Shaikhly Authority in the Pre-oil Gulf: An HistoricalAnthropological Study," History and Anthropology 17 (2006): 202-4.
} 
A proteção britânica e as legiões de soldados anexados elevaram e formalizaram os nichos da família em cada sheikhdom ${ }^{7}$. Essa proteção externa também deu à elite dominante da península uma participação considerável na manutenção de um status quo conservador ${ }^{8}$. Na Arábia Saudita uma teia de laços políticos e militares com os EUA dava proteção similar para a família governante AlSaud depois de 1945, enquanto, no Omã, a influência britânica, que era informal, ainda que incisiva, mantinha certo controle sobre o regime do Sultão Bin Taimur (governo entre 1932-70) ${ }^{9}$.

Apesar de não serem monolíticos e capazes de incluir politicamente indivíduos progressistas, como Abdullah al-Tariki ${ }^{10}$ (o "Xeique Vermelho") na Arábia Saudita, os regimes dos Estados do Golfo desenvolveram uma reputação de cautela política que contrastava fortemente com os movimentos populares e radicais de libertação nacional em outras partes do mundo em desenvolvimento. A aplicação pragmática de estratégias de sobrevivência lhes permitiu gerir o impacto da transformação sócioeconômica das receitas do petróleo em suas políticas. Isso desafiou a opinião prevalecente entre os cientistas políticos, como Karl Deutsch e Samuel Huntington, que previu o seu fim nas décadas de 1950 e 1960. A teoria do "Dilema do Xeique" argumentava que a maioria das monarquias tradicionais remanescentes colapsaria por pressão por reformas políticas e de forças modernizadoras, que oprimiriam políticas tradicionais "fracas"11.

Considerações internas e externas reforçaram uma posição política conservadora, que distinguiu os Estados do Golfo da maioria dos Estados póscoloniais em outras regiões do mundo. A divergência de visões de mundo se tornou clara durante a rebelião marxista na província de Dhofar, no Omã, entre 1965 e 1975. Oficiais da República Democrática Popular do Iêmen, que apoiava a Frente Popular para a Libertação de Omã e do Golfo Pérsico, retrataram a campanha como uma "guerra de libertação contra a ocupação estrangeira" dos "fantoches do colonialismo no Omã" e seu "governo cliente", apoiado pela assistência política e militar britânica ${ }^{12}$.

\footnotetext{
${ }^{7}$ Regime governado por um Xeque.

${ }^{8}$ Lisa Anderson, "Absolutism and the Resilience of Monarchy in the Middle East," Political Science Quarterly 106 (1991): 9.

${ }^{9}$ Marc Valeri, Oman: Politics and Society in the Qaboos State. (London: Hurst \& Co., 2009), 64-6.

${ }^{10}$ Diretor Geral de Assuntos de Petróleo e Minerais (1954-60) e Ministro do Petróleo e Recursos Minerais (1960-62).

${ }^{11}$ Christopher Davidson, The United Arab Emirates: A Study in Survival (London: Lynne Riener, $2005), 66$.

12 Carta do Representante Permanente da República Popular Democrática do Iêmen ao SecretárioGeral das Nações Unidas, 26 de novembro de 1973. London: The National Archives, file FCO 8/2037.
} 
O Omã eventualmente derrotou a rebelião em Dhofar, mas com altos níveis de apoio político e militar britânico, que se estendeu bem além da retirada britânica do Golfo em 1971. A campanha visivelmente demonstrava a extensão da divergência dos Estados do Golfo de trajetórias políticas dominantes no mundo em desenvolvimento em uma época em que oficiais na Arábia Saudita não apenas lideravam o caminho com pronunciamentos anticomunistas, mas encorajavam a formação de organizações islâmicas conservadoras para balancear grupos de esquerda ou alternativas de oposição secular. ${ }^{13}$

Além disso, essa dependência complicou e atrasou a emergência de elos tangíveis com as principais economias emergentes, como a China, as quais apoiaram ativamente o movimento revolucionário anti-imperialista de Dhofar ${ }^{14}$. Quando o Kuwait estabeleceu relações diplomáticas com a China, em 1971, ele agiu contra o fluxo da diplomacia do Golfo. Em outras partes (do Golfo), a normalização das relações não aconteceu até o anúncio de Deng Xiaoping, em 1978, de que a China moderaria suas políticas. Omã estabeleceu relações com a China em 1978, os Emirados Árabes em 1984, o Qatar em 1988, o Barein em 1989 e a Arábia Saudita em $1990^{15}$.

No entanto, as décadas de 1960 e 1970 testemunharam as ligações iniciais entre os Estados do Golfo e outros países e regiões do Sul geográfico. Isto ocorreu, primeiramente, no Kuwait e na Arábia Saudita, com embasamentos bastante diferentes. $\mathrm{O}$ estabelecimento precoce de relações do Kuwait com a China espelhou-se na troca de representantes diplomáticos com a União Soviética, em 1963. Ambas as decisões consideravelmente anteciparam movimentos similares de outros Estados do Golfo, e refletiram o equilíbrio das relações do Kuwait com as superpotências durante a Guerra Fria ${ }^{16}$.

Uma abordagem internacionalista semelhante marcou o início da política do Kuwait de ajuda externa ao desenvolvimento, como o Fundo para o Desenvolvimento Econômico Árabe do Kuwait (FDEAK), formado em dezembro de 1961 - apenas seis meses após a independência. Uma combinação de fatores políticos, econômicos e militares está por trás de sua criação. Esses fatores incluíam um

\footnotetext{
13 Fred Halliday, The Middle East in International Relations: Power, Politics and Ideology (Cambridge: Cambridge University Press, 2005), 122-3.

${ }^{14}$ Steve Yetiv e Chunlong Yu, "China, Global Energy and the Middle East," Middle East Journal 61 (2007): 201.

15 Christopher Davidson, "Persian Gulf-Pacific Asia Links in the 21 $1^{\text {st }}$ Century: A Marriage of Convenience?" LSE Kuwait Programme Working Paper 7 (2010), 5.

${ }^{16}$ Até meados dos anos 1980, o Kuwait foi o único Estado do Golfo que manteve uma relação política, financeira e militar ativa com a URSS.
} 
sentimento de responsabilidade entre os responsáveis pela política do Kuwait de que uma parcela de sua riqueza advinda do petróleo recém-descoberto devesse ser redistribuída para comunidades árabes mais pobres, através da provisão de educação, saúde e de outros serviços sociais e essenciais. ${ }^{17}$ Isso também institucionalizou exemplos precoces de apoio pan-árabe, antecipando tanto a independência do Kuwait quanto a criação do FDEAK, quando o Kuwait financiou a dragagem do canal de Dubai, entre 1958 e 1960, após um apelo do governante de Dubai para o seu rico homólogo do norte ${ }^{18}$.

A partir do exemplo do Kuwait, o governo de Abu Dhabi fundou o Fundo para o Desenvolvimento Econômico Árabe de Abu Dhabi (agora chamado Fundo de Abu Dhabi para o Desenvolvimento - ADFD, em inglês) em 1971, enquanto o Fundo Saudita para o Desenvolvimento foi formado em 1974. Essas três agências governamentais foram seguidas pela criação de agências de ajuda mútua, na metade dos anos 70. O Kuwait foi fundamental para a formação do Fundo Árabe para o Desenvolvimento Econômico e Social (FADES), em 1974, e Abu Dhabi estabeleceu o Fundo Monetário Árabe em 1975. Também em 1975, o Banco Islâmico de Desenvolvimento formado em Jeddah como uma instituição multilateral de desenvolvimento que promovia as finanças Islâmicas. Em 1980, o príncipe Saudita Talal bin Abdul Aziz, que recomendou a formação do Programa do Golfo para a Organização das Nações Unidas para o Desenvolvimento, tornou-se seu presidente.

Esse conjunto de canais de assistência bilateral e multilateral significou que as contribuições de ajuda dos Estados do Golfo excederam em muito as dos países desenvolvidos: entre 1974 e 1979, durante um período contínuo de altos preços do petróleo, as contribuições do Kuwait, Qatar, Arábia Saudita e Emirados Árabes Unidos totalizou entre seis e oito por cento de seus respectivos PIBs, em comparação com um terço de um por cento para os países do Comitê de Assistência ao Desenvolvimento da OCDE 19 .

Esses fundos, focados inicialmente em países árabes e islâmicos, foram ampliados, como forma de fornecer assistência aos países em desenvolvimento, como um todo. Assim, o Banco Árabe para o Desenvolvimento Econômico na África (BADEA), fundado em Cartum, em 1974, cobria países que eram membros da Organização da União Africana, mas não da Liga Árabe. Semelhante ao FADES, ele

17 Abdul-Reda Assiri, Kuwait's Foreign Policy: City-State in World Politics (Boulder: Westview Press, 1990), 26.

${ }^{18}$ Christopher Davidson, Dubai: The Vulnerability of Success (London: Hurst \& Co., 2008), 86.

19 Sultan Barakat e Steve Zyck. "Gulf State Assistance to Conflict-Affected Environments." LSE Kuwait Programme Working Paper 10 (2010, 7-11). 
expandiu-se para além do mundo Árabe para financiar projetos em outros lugares; em 2006, o BADEA e o FADES co-financiaram uma ferrovia de $264,5 \mathrm{~km}$ na Namíbia ${ }^{20}$.

A segunda maior instância da interação dos Estados do Golfo com o Sul global durante este período ocorreu com a criação de instituições e redes islâmicas internacionais, facilitadas pelos fluxos de receitas do petróleo na Arábia Saudita. Isto ampliou o "Soft Power" transnacional da Arábia Saudita e alimentou a criação da Liga do Mundo Muçulmano (1962), da Organização da Conferência Islâmica (1972), da Assembleia Mundial da Juventude Muçulmana (1972) e da Organização Internacional da Libertação Islâmica $(1975)^{21}$. Ironicamente, esses programas de extensão reforçaram a defesa conservadora que afastou os Estados do Golfo dos conflitos políticos e ideológicos prevalecentes daquele período. O rei Faisal bin Abdul Aziz criou esses programas de extensão para combater a influência tanto do nacionalismo pan-Arabista quanto do comunismo ${ }^{22}$.

Ao lado dos corpos institucionalizados listados anteriormente, seja no Estado saudita ou através de mais esforços privados, investimentos nas redes internacionais de caridade e organizações de bem-estar social, mesquitas, escolas teológicas e ONGs, mudaram o quadro político de referência do Islã, de suas raízes em nível estatal para um âmbito transnacional. Esta "virada" islâmica aconteceu primeiramente durante o reino do rei Faisal (1964-1975). Ela diferiu da articulação pan-árabe de alcance saudita, durante o reinado do antecessor de Faisal, Saud (1953-1964). Indiscutivelmente, os investimentos em redes de caridade também esboçaram as formas da sociedade civil mundial, mais comumente associadas aos conceitos ocidentais de globalização nos anos 1990 e $2000^{23}$.

A dispersão do Islã patrocinado pela Arábia Saudita se tornou um importante veículo para reforçar e projetar a legitimidade do reino em comunidades islâmicas em todo o mundo. Ela salientava que o transnacionalismo havia sido concebido para ser tanto uma estratégia política quanto uma obrigação religiosa, e como ele tentava cooptar e abrir canais com vertentes potencialmente divergentes do Islã, em direção

\footnotetext{
20 Ibid. 11.

21 Roger Hardy, "Ambivalent Ally: Saudi Arabia and the "War on Terror'," In Kingdom without Borders: Saudi Arabia's Political, Religious and Media Frontiers, ed. Madawi Al-Rasheed. )London: Hurst \& Co., 2008), 101.

${ }^{22}$ Morten Valbjorn and Andre Bank, "Signs of a New Arab Cold War: The 2006 Lebanon War and the Sunni-Shi'i Divide," Middle East Report 242 (2007): 7-8.

23 Marc Lynch, "Globalization and Arab Security," in Globalization and National Security, ed. Jonathan Kirshner. (New York: Routledge, 2006), 191-2.
} 
à aquisição do reconhecimento muito desejado por al-Saud como guardião dos lugares sagrados do Islä ${ }^{24}$.

Os Estados do Golfo também participaram de coalizões embrionárias de países em desenvolvimento. Como um dos dois únicos Estados independentes no Golfo, à época - o Omã sendo o outro - a Arábia Saudita participou da Conferência Ásia-África em Bandung, em 1955. Todos os seis aderiram posteriormente ao Movimento dos Não-Alinhados, quando conquistaram suas independências nos anos após sua criação, em 1961. No entanto, as prioridades da Arábia Saudita voltaram-se para o engajamento pan-islâmico, seguindo a ascensão de Faisal, em 1964, e a criação da Organização da Conferência Islâmica, em 1972.

A Arábia Saudita e o Kuwait estavam entre os membros fundadores do G77, uma coalizão na ONU de países em desenvolvimento, da qual Bahrein, Omã, Qatar e Emirados Árabes Unidos vieram a fazer parte. O envolvimento nesses grupos "frouxos" de países em desenvolvimento deu certa estrutura para as interações do Golfo com o Sul Global, no período pré-1991, embora as relações bilaterais com países importantes, inclusive a China, como mencionado antes, começaram a aquecer somente na década de $1980^{25}$.

\section{A internacionalização do Golfo e o aprofundamento da cooperação Sul-Sul}

A Guerra do Golfo, em 1991, foi um divisor de águas na postura internacional dos Estados do Golfo. A libertação do Kuwait por uma coalizão multinacional composta por 34 nações ocorreu em um momento de profundas mudanças no sistema internacional. Ela coincidiu com o fim da Guerra Fria e com a aceleração da mudança política global ${ }^{26}$.

A globalização aprofundou e ampliou as relações entre os Estados do Golfo e o sistema internacional. Ela expandiu essas preocupações conjuntas para além do setor de hidrocarbonetos. A energia manteve-se importante para as velozes economias emergentes, como Índia e China, que, em 1993, tornaram-se importadores líquidos de produtos petrolíferos ${ }^{27}$. Essas considerações sobre o petróleo foram aumentadas por

\footnotetext{
${ }^{24}$ Em 1986, o rei Fahd (reinou de 1982-2005) se tornou o primeiro rei da Arábia Saudita a adotar o título de "Gaurdião das Duas Mesquitas Sagradas".

25 Entrevista pessoal, Londres, maio de 2010.

${ }^{26}$ Ver, por exemplo, David Held and Anthony McGrew, com David Goldblatt e Jonathan Perraton, Global Transformations (Cambridge: Polity Press, 1999).

${ }^{27}$ Mahmoud Ghafouri, "China's Policy in the Persian Gulf," Middle East Policy 16 (2009), 80.
} 
novos alinhamentos geopolíticos e econômicos, que se aceleraram nos anos 2000, sustentando altos preços do petróleo entre 2002 e 2008 - e a presença do próprio recurso - lançaram os Estados do Golfo como importantes atores globais.

Embora os Estados do Golfo possuíssem um perfil internacional complexo e multifacetado bastante enraizado, um processo de mudança de gerações entre as elites dominantes no final dos anos 1990 e início dos anos 2000, interagiu com um período de rápido acumulo de capital a partir do segundo boom dos preços do petróleo. Além disso, uma combinação de suas reservas de hidrocarbonetos e recursos financeiros, e as decisões críticas sobre como utilizá-los, testemunhou a transformação dos Estados do CCG no centro de gravitação geoeconômico na Ásia Ocidental $^{28}$.

Laços aprofundados com o Sul e o Leste da Ásia, com a África e, posteriormente, com os países sul-americanos, simultaneamente internacionalizaram o Golfo e promoveram seu realinhamento com a ordem global. Ligações Sul-Sul ressurgentes se encaixam nesse padrão de reposicionamento dos Estados do Golfo através de novos acordos bi e multilaterais, parcerias e iniciativas, e através de possibilidades oferecidas pelo acumulo de maiores receitas dos hidrocarbonetos.

As relações políticas e de segurança dos Estados do Golfo com o Ocidente sobreviveram ao estresse colocado sobre eles, no rescaldo dos atentados terroristas de 11 de setembro de 2001 nos Estados Unidos. Essas relações permanecem como uma parte integrante para a estabilidade e a segurança da região. No entanto, a internacionalização do Golfo sutilmente reformulou as relações internacionais. Esta reformulação combinou decisores políticos do GCC com uma convergência cada vez mais global de até então discordantes tendências políticas e ideológicas em grande parte do Sul Global. Assim, os laços da Índia com o Golfo reapareceram desde os anos 1990, centrados, mas não limitados, a mais de 4,5 milhões de expatriados indianos no Conselho de Cooperação do Golfo ${ }^{29}$. Uma série de visitas bilaterais de alto nível, progressivamente alargou o leque de ligações para cobrir a segurança, defesa, econômia e arenas de energia.

Após um congelamento profundo que começou durante a liderança de Indira Gandhi e que continuou na década de 1990, os laços foram descongelados após a

\footnotetext{
28 Ver David Held e Kristian Coates Ulrichsen, eds., The Transformation of the Gulf: Politics, Economics and the Global Order (London: Routledge, 2011).

29 John Willoughby, "Ambivalent Anxieties of the South Asian-Gulf Arab Labour Exchange," In Globalization and the Gulf, eds. John Fox, Nada Mourtada-Sabbah and Mohammed Al-Mutawa (London: Routledge, 2006), 228.
} 
visita do Ministro das Relações Exteriores indiano Jaswant Singh, em 2001, à Arábia Saudita e a visita do rei Abdullah bin Abdul Aziz, em 2006, à Índia. Estas ligações culminaram, em fevereiro de 2010, na atualização da relação bilateral em uma Parceria Estratégica, com promessas de "uma nova era baseada no envolvimento econômico e nas oportunidades emergentes" ${ }^{n 0}$.

As relações bilaterais desempenharam e continuam desempenhando um papel importante nas Relações Internacionais dos Estados do CCG. No entanto, a proliferação de instituições regionais e globais e a formação de novas camadas de governança abrem novos caminhos e canais para a Cooperação Sul-Sul. Ao mesmo tempo, a crise financeira e econômica global e as intervenções militares caóticas no Iraque e Afeganistão expuseram as falhas do Consenso de Washington e da doutrina de segurança liderada pelos EUA. Estas debilidades nos dois principais pacotes de políticas que definiram a agenda global nos anos 1990 e 2000 constituiram uma oportunidade para reavaliar parcialmente a natureza e as formas de governança regional e global ${ }^{31}$. A posição da Arábia Saudita no G20 e no conselho do FMI, visivelmente representando os realinhamentos emergentes das potências emergentes não-ocidentais na remodelação da arquitetura de governança internacional.

O Ministro das Finanças, Ibrahim Abdulaziz Al-Assaf juntou-se aos seus homólogos de Brasil, Rússia, Índia e China, na sua defesa de que os países em desenvolvimento do FMI deveriam ter maiores poderes de voto, dada a "sobrerepresentação" dos Estados desenvolvidos ${ }^{32}$. Em 2011, Al-Assaf voltou a levantar a questão com Christine Lagarde, quando ela procurou o apoio das economias emergentes em sua (bem sucedida) campanha para suceder Dominique Strauss-Kahn como chefe do FMI $^{33}$.

Os Oficiais do Golfo começaram a delinear suas visões sobre o reequilíbrio global. Durante o auge da crise financeira, o Kuwait organizou e sediou, em janeiro de 2009, a Cúpula Árabe de Desenvolvimento Econômico e Social ${ }^{34}$. Mais tarde, em 2009, o Primeiro Ministro e Ministro das Relações Exteriores do Qatar, Sheikh Hamad bin Jasim bin Jabr Al-Thani, reclamou uma remodelação "[d]os quadros de

\footnotetext{
${ }^{30}$ Entrevistas pessoais, Abu Dhabi (Outubro de 2009) e Londres (maio de 2010).

${ }^{31}$ David Held. "Global Challenges: Accountability and Effectiveness." Open Democracy 17 January 2008.

32 "Saudi Says IMF Reforms Should Not Be at its Expense." The Peninsula, 5 de setembro de 2009.

33 "Saudi Arabia to Seek Greater Role in IMF," Gulf Daily News, 12 de junho de 2011.

34 “Arab Summit in Kuwait to Discuss Gaza Reconstruction.” Arab News, 19 de janeiro de 2009.
} 
organização do sistema político dominante", e para refletir a emergência de uma ordem multipolar, em que "o Ocidente não era o único ator no mundo"35.

Na preparação para a segunda reunião do G20 em Londres, em abril de 2009, os contornos de um novo e frouxo alinhamento de economias emergentes voltaram-se para a correção de um desequilíbrio de representação na arquitetura financeira internacional. Al Assaf deixou claro que o Reino defendia um aumento nas ações e poderes de voto nas instituições financeiras internacionais ${ }^{36}$. Em paralelo, o movimento em direção à coalizões emergentes de "Potências Médias" deu um passo adiante em junho de 2009, com a criação do Fórum BRIC, em Ecaterimburgo, na Rússia. Esta nova cúpula anual das quatro principais economias emergentes (que posteriormente se reuniram em Brasília, em 2010, e Sanya, na China - com a participação da África do Sul - em 2011) criou uma plataforma destinada a contrabalançar a liderança dos EUA percebida no sistema global ${ }^{37}$. Antes da terceira reunião do G20, em Pittsburgh, em setembro de 2009, Al Assaf juntou-se aos BRICs no apoio a uma proposta para aumentar a representação dos países emergentes no FMI, para refletir com maior precisão o seu peso na economia global ${ }^{38}$.

Oficiais do CCG também participaram plenamente, em julho de 2009, da cúpula trienal do Movimento dos Países Não-Alinhados sobre como reestruturar a governança global para incorporar a participação dos países em desenvolvimento em processos decisórios. A cúpula reclamou a reforma das instituições internacionais que, nas palavras do Primeiro Ministro indiano Manmohan Singh, "continuam a se basear em cartas escritas a mais de sessenta anos, embora o mundo tenha mudado muito desde então" 39 . As autoridades do Kuwait também aproveitaram a ocasião para anunciar doações de US\$500 milhões para um fundo de apoio a pequenos e médios projetos de desenvolvimento em economias emergentes, e US\$300 milhões para um fundo de combate à pobreza na África ${ }^{40}$.

Esses contornos emergentes adquiriram uma dimensão multilateral com a decisão, em 2009, de instalar a recém-criada Agência Internacional de Energias Renováveis(IRENA), em Abu Dhabi. Da mesma forma, o papel do Qatar na hospedagem e transformação do Fórum dos Países Exportadores de Gás em uma organização intergovernamental que inclui líderes mundiais (e não-ocidentais) em

35 “Qatari PM Stresses Rule of Law to Face Challenges." Gulf Times, 31 de maio de 2009.

36 Saudi Gazette, 15 de março de 2009.

37 Russia Today, 15 de junho de 2009.

38 The Peninsula, 5 de setembro de 2009.

39 “NAM Leaders Call for "New Economic Order.” Oman Daily Observer, 16 de julho de 2009.

40 "Developing Countries Concerned Over Economic Crisis: Kuwait." Kuwait News Agency, 13 de julho de 2009. 
produção de gás, é outro exemplo do papel importante na governança regional, não regional e internacional dos Estados do Golfo ${ }^{41}$.

A importância crítica de questões relacionadas a energia na condução e aprofundamento das relações multilaterais entre os Estados do CCG e outros blocos de economias emergentes tornou-se evidente na primeira reunião ministerial entre CCG e Associação de Nações do Sudeste Asiático (ASEAN), em junho de 2009. Oficiais discutiram os planos para a transição rumo à construção de um bloco comercial, de acordo com os requisitos de segurança energética dos Estados da ASEAN em equilíbrio com os requisitos de segurança alimentar dos Estados do CCG. O Secretário-Geral da ASEAN, Suring Pitsuan, observou que "você tem o que nós não temos, e nós temos em abundância o que você não tem, por isso precisamos uns dos outros" 42 .

No entanto, os investimentos agricolas dos Estados do CCG na Ásia e África expôs as alegações do "agro-imperialismo" e de "apropriação fundiária" neocolonialista. Após a primeira entrega de uma carga de arroz de uma fazenda na Etiópia, financiada pela Arábia Saudita, em 2009, um artigo do Financial Times apontou que falhas nas plantações já tinham deixado 11 milhões de etíopes na dependência do Programa Mundial de Alimentos para o seu sustento. A cobertura da mídia focada na falta de normas internacionais ou nas garantias legais para proteger os agricultores locais, acusou a Arábia Saudita e os Emirados Árabes de "uma corrida frenética para devorar as terras agrícolas em todo o mundo"43.

O panorama geral é mais sutil, e tem sido reconhecido como tal pela Organização para a Agricultura e Alimentação da ONU. Embora reconhecendo os "complexos e controversos temas econômicos, políticos, institucionais, legais e éticos", observou também que os Estados do Golfo estão investindo no desenvolvimento agrícola e nos ganhos de produtividade. Este é o tratamento que as iniciativas do Golfo, como a do rei Abdullah para a Iniciativa Árabe para o Investimento Estrangeiro e o Programa Nacional de Segurança Alimentar do Qatar priorizam. No entanto, o potencial de auto-prejuízo ${ }^{44}$ tornou-se evidente quando o governo pós-Mubarak no Egito congelou um grande negócio agrícola que o regime deposto tinha alcançado com holdings do Reino da Arábia Saudita ${ }^{45}$.

41 "Doha gears up to host Gas Exporting Countries' Forum." The Peninsula, 29 de Junho de 2009.

42 "Gulf States and ASEAN Eye New Trade Bloc Based on Food, Oil." The Peninsula, $1^{\circ}$ de julho de 2009.

43 Thomas Lippman, "Saudi Arabia's Quest for 'Food Security'," Middle East Policy 17 (2010): 92-3.

${ }^{44} \mathrm{O}$ termo usado em ingles é Blowback

45 "Egypt Freezes Saudi Arabian Farm Land Deal," The National, 12 de Abril de 2011. 
Assim, as coalizões emergentes entre os Estados do Golfo e outras grandes economias emergentes injetam uma nova dinâmica no sistema internacional. No entanto, estes novos alinhamentos diferem significativamente dos modelos anteriores de Cooperação Sul-Sul como a Nova Ordem Econômica Internacional na década de 1970. Este conjunto de propostas dos países em desenvolvimento tentou revisar o sistema econômico de Bretton Woods promovendo coletivamente seus interesses em questões como a melhoria dos seus termos de troca e a redução das tarifas dos países desenvolvidos ${ }^{46}$.

Diferentes motivações guiam os Estados do Golfo no seu envolvimento atual com o sistema internacional. Ao invés de tentar mudar a estrutura da economia global, eles estão tentando maximizar a sua própria influência dentro dela. Liderados pela posição da Arábia Saudita no G20, eles formaram coalizões de conveniência com outras grandes economias emergentes para defender uma mudança na representação. Assim, o presidente chinês Hu Jintao visitou a Arábia Saudita em fevereiro de 2009, e prometeu trabalhar em conjunto "com vistas a reformar as instituições financeiras globais"47. Mas isso também levanta a possibilidade de de que países em desenvolvimento possam começar a ver os Estados do Golfo menos como um contrapeso no sistema internacional, e mais como uma potência exploradora de seu próprio direito.

\section{Modalidades dos Estados do Golfo - Cooperação Sul-Sul}

Esta interligação entre segurança alimentar e energética reflete uma série de decisões políticas tomadas pelos Estados do CCG para terceirizar a produção de alimentos através de agro-investimentos estratégicos. Em janeiro de 2009, o rei Abdullah, da Arábia Saudita, criou um fundo de investimento (Iniciativa para Investimento Agrícola no Exterior) de SR 3 bilhões (cerca de US\$ 800 milhões) para apoiar o investimento do setor privado nas empresas da Arábia Saudita em projetos agrícolas no exterior. Em fevereiro, a Companhia de Desenvolvimento Agrícola Hail anunciou um investimento de mais de US\$ 4 milhões e meio, ao longo de dois anos, para desenvolver 9 mil hectares de terras no Sudão. Outra empresa Saudita (Companhia Star de Desenvolvimento Agrícola) investiu no cultivo de arroz e outras culturas em 1,2 milhões de acres na Etiópia ${ }^{48}$. No Qatar, a Companhia de Alimentos

\footnotetext{
46 Robert Cox, "Ideologies and the New International Economic Order: Reflections on Some Recent Literature," International Organization 33 (1979): 260-3.

47 “China to Boost Relations with GCC: President Hu," Arab News, 12 de fevereiro de 2009.

${ }^{48}$ Lippman, "Saudi Arabia's Quest,." 92.
} 
Hassad lançou, em julho de 2008, uma subsidiária de US\$ 1 bilhão: a Qatar Investment Authority. Em 2009, ela chegou a um acordo de US\$ 500 milhões para plantar trigo e arroz no Sudão e, em 2010, continuou, finalizando a compra de uma fábrica de açúcar no Brasil. Esta compra foi notável, porque era capaz de atender toda a demanda do Qatar para o açúcar bruto e refinado ${ }^{49}$.

O exemplo dos agro-investimentos na Ásia, África e em outros lugares demonstra como as modalidades específicas de cooperação reformulam as relações internacionais dos Estados do CCG, especialmente com parceiros emergentes. A mesma tendência é observada nas estratégias de investimento baseados em fundos soberanos do CCG. Mudanças significativas nas estratégias de investimento ao longo dos últimos dez anos diversificaram os fluxos de dinheiro, de sobre-representação na América do Norte e nos mercados europeus, em direção a um maior investimento nas economias emergentes. Esta diversificação respondeu, em parte, aos eventos do $11 \mathrm{de}$ setembro de 2001 e a temores de uma repercussão política, como foi o caso quando o Congresso dos EUA impediu a Dubai Ports World de assumir o controle dos portos estadunidenses, em 2006. Essa mudança também reflete a crescente atratividade dos mercados emergentes, particularmente na China, Índia, Malásia, Hong Kong, Taiwan e Cingapura.

A Abu Dhabi Investment Authority e o Qatar Investment Authority ditam o caminho na busca de oportunidades de investimento em mercados emergentes. Maiores fluxos de investimento direto estrangeiro em outros países do Oriente Médio e Norte da África (MENA) impulsionaram os mercados de capitais regionais e criaram novas sinergias entre os investidores do Golfo (particularmente em instituições financeiras islâmicas) e empresas locais ${ }^{50}$. Em 2010, a região da ÁsiaPacífico atraiu a maior proporção de investimentos diretos feitos por Fundos Soberanos - até $60 \%$ do total. A Qatar Investment Authority, por exemplo, investiu US\$ 6 bilhões no Banco Agrícola da China ${ }^{51}$.

Os fluxos de investimento aumentaram as transferências existentes através de remessas e da ajudas ao desenvolvimento dos países ricos em petróleo paraos Estados pobres em recursos. Além dos Estados do Golfo, a prestação histórica de Ajuda Oficial ao Desenvolvimento (ODA) para o mundo árabe e islâmico (como descrito na primeira seção deste artigo), a assistência mais recententemente tem sido focada em

\footnotetext{
49 "In Bid for Food Security, Qatar Grows Seeds Globally." The National, 2 de setembro de 2010.

${ }^{50}$ Gawdat Bahgat, "Sovereign Wealth Funds: Dangers and Opportunities," International Affairs 84 (2008): 1195-8.

51 "Investing at Home," The Gulf Business News and Analysis, August 2011, pp.14-5.
} 
projetos ligados diretamente à Cooperação Sul-Sul, e em projetos de prestação de ajuda humanitária aos Estados frágeis.

O Kuwait e os Fundos Sauditas, que foram os mais focados globalmente, financiaram projetos na Europa, América Latina e para países pobres na África Subsaariana e no sudeste asiático. O Banco Árabe para o Desenvolvimento Africano (BADEA), o Fundo Árabe para o Desenvolvimento Económico e Social (AFESD) e o Banco Islâmico de Desenvolvimento (BIsD) voluntariamente ofereceram apoio a projetos que promovessem a integração econômica regional e a cooperação Sul-Sul. Assim, o BADEA financiou projetos rodoviários para promover o comércio entre Burkina Faso, Chade, Serra Leoa, Ruanda e Camarões, em 2007, enquanto o AFESD, em parceria com o Banco Islâmico de Desenvolvimento, apoiou a integração regional na África através das rodovias Trans-Sahariana e Trans-Sahel ${ }^{52}$.

Os principais beneficiários da ODA do Golfo para as áreas afetadas pelo conflito, entre 2000 e 2007, incluiram Paquistão, Afeganistão, Iraque, Sudão, Eritréia, Mauritânia, Níger e Ilhas Salomão ${ }^{53}$. Os Estados do CCG também levaram assistência ao Iêmen em novembro de 2006, na Conferência de Doadores em Londres onde, entretanto, o "constrangimento de capacidadess" restringiu a real distribuição à apenas $7 \%$ dos US\$4 bilhões prometidos aos Estados do Golfo ${ }^{54}$.

Não obstante, os Estados do CCG assumiram posições de liderança no renovado compromisso internacional com o Iêmen, em 2010, tanto dentro do Fórum de Amigos do Iêmen quanto na organização da renião de alto nível de Riyadh de doadores regionais e internacionais, em fevereiro de 2010. Além disso, as promessas de Ajuda Oficial ao Desenvolvimento do CCG ao Iêmen diminuiram as doações ocidentais, tendo a Arábia Saudita prometido US\$ 1,25 bilhão em 2009, em comparação com a participação americana de US\$ 63 milhões ${ }^{55}$.

A assistência a Estados frágeis e afetados por conflitos se interliga ao envolvimento do Qatar com a mediação de conflitos. Impulsionado pelo seu sucesso inicial no Acordo de Doha, que terminou com um impasse político de dezoito meses entre facções rivais no Líbano, em 2008, o Qatar foi, desde então, o mediador diplomático entre o governo sudanês e o Movimento Justiça e Igualdade de Darfur,

\footnotetext{
52 “Arab Development Assistance: Four Decades of Cooperation." Washington, D.C.: The International Bank for Reconstruction and Development/The World Bank, julho de 2010.

${ }^{53}$ Habiba Hamid, “Overseas Development Assistance from the UAE: Structuring Donor Relations in the Context of the Arab League's Fragile States," Dubai School of Government Working Paper 09-03 (2009): 4 .

54 "Gulf States Key to Resolving Yemen's Ills." Agence France-Presse, 29 de janeiro de 2010.

${ }^{55}$ Ginny Hill, "What is Happening in Yemen?" Survival 52.(2010): 2-3.
} 
em 2009, e entre o governo iemenita e os líderes da rebelião Houthi, em 2010, se oferecendo, também para intermediar negociações entre o governo das Filipinas e a Frente Moro de Libertação Islâmica em 2008-956 .

Outros mecanismos que facilitam o envolvimento dos Estados do Golfo com a Cooperação Sul-Sul, incluem a expansão e transformação de questões até então predominantemente bilaterais em assuntos multilaterais e marcos regulatórios. Um exemplo notável disto ocorreu na implementação do Diálogo de Abu Dhabi sobre o Trabalho Contratual para a Cooperação entre os Países de Origem e Destino na Ásia.

Este diálogo oficial reuniu os onze países exportadores do Colombo Process (Afeganistão, Bangladesh, China, Índia, Indonésia, Nepal, Paquistão, Filipinas, Sri Lanka, Tailândia e Vietnã), com nove países importadores de mão-de-obra (Bahrain, Kuwait, Malásia, Omã, Qatar, Arábia Saudita, Cingapura, Emirados Árabes Unidos e Iêmen). Organizada e sediada pelos Emirados Árabes Unidos, em janeiro de 2008, essa reunião constituiu um marco na cooperação regional, com base nos interesses mútuos dos países de origem e destino de mão de obra ${ }^{57}$. Deu atenção especial ao desenvolvimento, compartilhamento de informações, capacitação e cooperação interestatal $^{58}$. Ela também demonstrou como exemplos existentes de Cooperação Sul-Sul nece caso o Colombo Process, podem ser transformados em estruturas maiores, interregionais e inter-setoriais de cooperação e diálogo.

\section{Conclusão}

A rápida emergência recente dos Estados do CCG à posições de liderança internacional representa um momento de grande oportunidade para a Cooperação Sul-Sul. Em parte, isso é baseado em interesses econômicos e comerciais comuns. Enquanto as considerações sobre segurança energética não são novas, a escala e as múltiplas dimensões das iniciativas recentemente anunciadas, são inovadores.

\footnotetext{
56 "Yemen Opens Talks with Shia Rebels on Peace Deal in Doha." Agence France-Presse, 25 de agosto de 2010; "The Philippines: Running in Place in Mindanao." International Crisis Group Policy Briefing 88, 16 de Fevereiro de 2009.

57 Informações sobre o Diálogo de Abu Dhabi podem ser encontradas no sita da Organização Internacional do Trabalho, http://www.ilo.org/sapfl/News/lang--en/WCMS_090660/index.htm (acessado em 14 de março de 2012).

${ }^{58}$ Ibid: 'Abu Dhabi Dialogue on Contractual Labour for Cooperation between Countries of Origin and Destination in Asia,' http://www.ilo.org/sapfl/News/lang--en/WCMS_090660/index.htm (acessado em 14 de março de 2012).
} 
Essas inovações incluem acordos substanciais de joint ventures entre Kuwait e China (simbolizado pela criação da Companhia de Investimento Kuwait-China, em 2005). Essas inovações também incluem acordos entre a empresa saudita Aramco e a Sinopec, para a construção de refinarias e usinas petroquímicas na China. Significativamente, essas relações comerciais, diversificadas para além da sua base de hidrocarbonetos, tem se ramificado em interdependências dinâmicas mútudas com parceiros em toda a África e (sobretudo) na Ásia ${ }^{59}$.

Mesmo que a Coréia do Sul que não seja membro do Sul geográfico, uma troca de energia, em agosto de 2010, entre a Corporação Nacional de Petróleo da Coréia e a Companhia Nacional de Petróleo de Abu Dhabi, exigiu um empreendimento conjunto para a exploração de petróleo e gás, para a construção de um estoque coreano de petróleo e para a construção de uma instalação de armazenamento em Abu Dhabi. O crescimento e a evolução de um simples acordo em um grande projeto bilateral, mostra que as relações econômicas podem se transformar em interdependências estratégicas, e até mesmo políticas, com outros países ${ }^{60}$.

Outros possíveis caminhos frutíferos para a Cooperação Sul-Sul em relação aos Estados do CCG incluem a energia/segurança alimentar descrita acima e a colaboração em programas civis de energia nuclear e a pesquisa de formas renováveis de energia. Na verdade, o acordo 'bilateral 123', de 2009, para a cooperação nuclear pacífica que os Emirados Árabes Unidos firmaram com os Estados Unidos constitui um modelo arquetípico.

Este modelo arquetípico serve como um exemplo que atende às necessidades dos estados nucleares fornecedores e de seus potenciais destinatários, n o qual os países que outrora buscavam capacidade energética nuclear civil podem basear suas estratégias ${ }^{61}$. A medida que os Estados do CCG assumem a liderança global em pesquisa de energias renováveis e nuclear (simbolizadas pelo anúncio da Arábia Saudita da Cidade do Rei Abdullah para Energia Nuclear e Renovável em Riyadh), os laços de cooperação em pesquisa e desenvolvimento de questões de energia podem gerar um impulso significativo no futuro do quadro de cooperação Sul-Sul.

O reequilíbrio global, conforme descrito neste capítulo, tem implicações profundas para o futuro da Cooperação Sul-Sul e para os Estados do Golfo, nesse

\footnotetext{
${ }^{59}$ Davidson, "Persian Gulf-Pacific Asia," 5, 17.

60 "South Korea, UAE to Cooperate on Energy Exploration, Stockpiling of Oil." Bloomberg, 2 de agosto de 2010.

${ }^{61}$ Bryan Early, "Strategies for Acquiring Foreign Nuclear Assistance in the Middle East: Lessons from the United Arab Emirates," Dubai School of Government Working Paper 09-11 (2009),: 4.
} 
contexto. Entre outras coisas, este reequilíbrio cria modelos alternativos de desenvolvimento econômico e esculpe caminhos para compromissos com as camadas de governança global e instituições internacionais. Os líderes políticos nos Estados do CCG têm mostrado entusiasmo particular com o modelo de "Estado desenvolvimentista" aplicado na Ásia Oriental. Isto caracteriza uma mistura pragmática do dirigismo estatal e da iniciativa privada, sendo Cingapura frequentemente citada como um modelo a seguir ${ }^{62}$.

No entanto, as novas pressões geradas pela Primavera Árabe de 2011 criaram a possibilidade de futuras divergências nas trajetórias de engajamento dos Estados do Golfo à Cooperação Sul-Sul. Por um lado, a Arábia Saudita surgiu como líder protetor do status quo, tentando proteger seus principais interesses regionais e de segurança. Apesar de ter apoiado a substituição de líderes que perderam sua legitimidade ou autoridade moral na Líbia e no Iêmen, ela interveio para esmagar os protestos pró-democracia no Bahrein e esbanjou assistência financeira ao Egito à e Jordânia $^{63}$.

A Arábia Saudita também lançou um anúncio surpresa ao CCG, dizendo que iria oferecer formas de associação para a Jordânia e o Marrocos. Juntamente com a implantação do Peninsula Shield Force do CCG, para restaurar a estabilidade no Bahrein, o movimento foi interpretado por alguns como revelador das "verdadeiras cores' dos Estados do CCG, como um clube de monarcas se unindo ${ }^{64}$. Essa interpretação mais negativa abrange também o ceticismo sobre os "agroinvestimentos $^{66}$ dos Estados do Golfo. Ela levanta a possibilidade de que o envolvimento global dos Estados do CCG é motivado pelas ambições dos Estados de maximizar a sua posição na ordem global em transformação, ao invés de qualquer apego normativo ao grupo dos países em desenvolvimento, do qual eles antigamente pertenciam.

Por outro lado, Qatar e Emirados Árabes Unidos estiveram ativamente envolvidos em reunir apoio árabe para a intervenção multi-nacional na Líbia, em março de 2011. Além de fornecer apoio aéreo à operação, os dois países sediaram diversas reuniões multilaterais de cúpula do Libya Contact Group. O Qatar também estendeu a assistência prática ao opositor Conselho Nacional de Transição, fornecendo assistência financeira e ajudando o país a comercializar e vender petróleo

\footnotetext{
${ }^{62}$ Martin Hvidt, "The Dubai Model: An Outline of Key Development-Process Elements in Dubai," International Journal of Middle East Studies 41 (2009): 399.

${ }^{63}$ F. Gregory Gause, "Is Saudi Arabia Really Counter-Revolutionary?" Foreign Policy, 9 de agosto de 2011.

${ }^{64}$ Mohammed Ayoob, "The GCC Shows its True Colors," Foreign Policy, 16 de março de 2011.
} 
nos mercados internacionais ${ }^{65}$. Nesse cenário mais otimista, os Estados do Golfo tornam-se atores globais mais ativos e responsáveis e utilizam sua influência para o benefício dos países em desenvolvimento de forma mais ampla. O padrão de investimentos, a mediação diplomática e o perfil de crescimento do Qatar sugerem um nível plausível, em termos individuais. É, no entanto, duvidoso que questões específicas do Qatar sejam representativas do CCG como um todo.

Este realinhamento de potências, portanto, tem consequências importantes para a evolução contínua da tomada de decisõs multilateral, em uma matriz de mudanças sistêmicas na arquitetura internacional do pós-Segunda Guerra Mundial. Em 2020, o amadurecimento de um sistema internacional verdadeiramente multipolar proporcionará múltiplas aberturas para coalizões de potências emergentes a fim de maximizar a influência e conexões. Os Estados do CCG desempenharão um papel significativo neste reequilíbrio global de formas, tanto positivas como negativas, tal como evidenciado pelas diferentes respostas à Primavera árabe.

Assim, é provável que a participação futura dos Estados do Golfo na Cooperação Sul-Sul estará longe de ser perfeita. A concorrência agressiva para o acesso aos territórios agrícolas na África e Ásia, por exemplo, carrega as sementes da tensão potencial com outros países que possuem estratégias de "agro-investimento", como a China; ou caso os preços das commodities continuem a subir, deixando as populações locais sem garantia de preços acessíveis para alimentos básicos. Essa mudança, portanto, tem o perigo de uma série de retrocessos sociais, se os termos de compromisso forem considerados desiguais para os produtores locais do país em questão.

Independentemente de ser positiva ou negativa, a trajetória global da participação dos Estados do Golfo na Cooperação Sul-Sul é, decididamente, crescente, com a multiplicação de conexões levando ao aumento das interdependências. Com a dissolução gradual de grande parte da relação estagnda pré-1991, um padrão mais amplo emerge, em que os Estados do Golfo projetam uma maior influência global, no qual o poder é mais difuso e refratado do que nunca.

65 “Qatar Takes a Bold Diplomatic Risk in Supporting Benghazi's Transitional Government," Gulf States Newsletter, 8 de abril de 2011. 


\section{REFERÊNCIAS}

Al-Rasheed, Madawi. Contesting the Saudi State: Islamic Voices From a New Generation. Cambridge: Cambridge University Press, 2007.

Anderson, Lisa. "Absolutism and the Resilience of Monarchy in the Middle East." Political Science Quarterly 106 (1991): 1-15.

Assiri, Abdul-Reda. Kuwait's Foreign Policy: City-State in World Politics. Boulder: Westview Press, 1990.

Bahgat, Gawdat. "Sovereign Wealth Funds: Dangers and Opportunities." International Affairs 84 (2008): 1189-1204.

Barakat, Sultan. and Steve Zyck, "Gulf State Assistance to Conflict-Affected Environments." London: LSE Kuwait Programme Working Paper 10 (2010).

Cox, Robert. "Ideologies and the New International Economic Order: Reflections on Some Recent Literature." International Organization 33 (1979): 257-302.

Davidson, Christopher. The United Arab Emirates: A Study in Survival. London: Lynne Riener, 2005.

Davidson, Christopher. Dubai: The Vulnerability of Success. London. London: Hurst \& Co., 2008.

Davidson, Christopher. "Persian Gulf-Pacific Asia Links in the 21 ${ }^{\text {st }}$ Century: A Marriage of Convenience?" London: LSE Kuwait Programme Working Paper 7 (2010).

Early, Bryan. "Strategies for Acquiring Foreign Nuclear Assistance in the Middle East: Lessons from the United Arab Emirates." Dubai: Dubai School of Government Working Paper 09-11 (2009).

Ghafouri, Mahmoud. "China's Policy in the Persian Gulf." Middle East Policy 16 (2009): 80-92.

Halliday, Fred. The Middle East in International Relations: Power, Politics and Ideology. Cambridge: Cambridge University Press, 2005.

Hamid, Habiba. "Overseas Development Assistance from the UAE: Structuring Donor Relations in the Context of the Arab League's Fragile States." Dubai: Dubai School of Government Working Paper 09-03 (2009).

Hardy, Roger. "Ambivalent Ally: Saudi Arabia and the "War on Terror'." In Kingdom without Borders: Saudi Arabia's Political, Religious and Media 
Frontiers, edited by Madawi Al-Rasheed. London: Hurst \& Co., 2008. 99112.

Held, David. and Kristian Ulrichsen, editors. The Transformation of the Gulf: Politics, Economics and the Global Order. London: Routledge, 2011.

Held, David and Anthony McGrew, Goldblatt, David and Jonathan Perraton, Global Transformations. Cambridge: Polity Press, 1999.

Hill, Ginny. "What is Happening in Yemen?" Survival 52 (2010): 105-116.

Hvidt, Martin. "The Dubai Model: An Outline of Key Development-Process Elements in Dubai." International Journal of Middle East Studies 41 (2009): 397-418.

Lippman, Thomas. "Saudi Arabia's Quest for 'Food Security'." Middle East Policy 17 (2010): 90-98.

Lynch, Marc. "Globalization and Arab Security." In Globalization and National Security, edited by Jonathan Kirshner. New York: Routledge, 2006. 171200.

Metcalf, Thomas. Imperial Connections: India in the Indian Ocean Arena. Berkeley: University of California Press, 2007.

Nonneman, Gerd. "Determinants and Patterns of Saudi Foreign Policy: 'Omnibalancing' and 'Relative Autonomy' in Multiple Environments.' In Saudi Arabia in the Balance: Political Economy, Society, Foreign Affairs, edited by Paul Aarts and Gerd Nonneman. London: Hurst \& Co., 2005. 315351.

Onley, James and Suleyman Khalaf. "Shaikhly Authority in the Pre-oil Gulf: An Historical-Anthropological Study." History and Anthropology 17 (2006): 189-208.

Potter, Lawrence. The Persian Gulf in History. New York: Palgrave Macmillan, 2009.

Valbjorn, Morten and Andre Bank. "Signs of a New Arab Cold War: The 2006 Lebanon War and the Sunni-Shi'i Divide." Middle East Report 242 (2007): $6-11$.

Valeri, Marc. Oman: Politics and Society in the Qaboos State. London: Hurst \& Co., 2009.

Willoughby, John. "Ambivalent Anxieties of the South Asian-Gulf Arab Labour Exchange." In Globalization and the Gulf, edited by John Fox, Nada 
Mourtada-Sabbah and Mohammed Al-Mutawa. London: Routledge, 2006. 223-243.

Yetiv, Steve and Chunlong Lu. "China, Global Energy and the Middle East." Middle East Journal 61 (2007): 199-218. 


\section{RESUMO}

Esse artigo avalia o papel dos estados membros do Conselho de Cooperação do Golfo (CCG) - Bahrein, Kuwait, Omã, Qatar, Arábia Saudita e Emirados Árabes Unidos - no âmbito da cooperação Sul-Sul. Ele traça as diferentes fases de engajamento entre os Estados do Golfo e outros países em desenvolvimento, e a mudança das dinâmicas que os sustentam.

Essas fases demonstram profundas mudanças que refletiram ajustes na formulação de políticas em resposta a catalisadores domésticos, regionais e internacionais. Quando analisadas em conjunto, as forças internas e externas que pressionam os Estados do CCG moldam a perspectiva de análise deste artigo. Além disso, essas pressões internas e externas moldaram as contribuições dos Estados do Golfo para a Cooperação Sul-Sul, e definiram os realinhamentos intra-regionais e internacionais nos quais o CCG se engajou.

\section{PALAVRAS-GHAVE}

Conselho de Cooperação do Golfo; Cooperação Sul-Sul; Estados do Golfo. 


\title{
A CRISE FINANCEIRA E A HEGEMONIA DO DÓLAR
}

\author{
Marcelo Milan ${ }^{l}$
}

\section{Introdução}

Os anos 70 trouxeram várias mudanças para a economia global. Além dos choques do petróleo, que trouxeram forte desorganização econômica, o abandono do padrão dólar-ouro criou um potencial desestabilizador ainda maior (Block, 1977). Neste período, dados o tamanho e a importância da economia norte-americana, o dólar se consolidou como a moeda-chave do novo padrão monetário não-oficial que se seguiu ao declínio dos arranjos de Bretton Woods, constituindo-se em uma reserva global de valor e fonte da liquidez internacional dos mercados financeiros (Morgan, 2009). A adoção do padrão dólar-flexível deu aos Estados Unidos o poder de determinar os termos do desempenho econômico da economia global, por meio de variações nos fluxos de capitais (Serrano, 2003). As transações comerciais e financeiras tem no dólar norte-americano uma referência, o que tem implicações para a própria manutenção da posição hegemônica dos EUA. Fiori (1999) mostra as complexas relações entre rivalidade estatal, moeda e riqueza. No mesmo sentido, Vasudevan (2009b) argumenta que o padrão dólar flutuante representa uma inversão de um aspecto central do imperialismo, na medida em que agora a hegemonia é exercida por meio da absorção de capitais, mais do que exportação. Apesar das reações esperadas dentro de um sistema de concorrência e rivalidade intercapitalista, como a criação do Euro em 1999, e dos muitos obstáculos enfrentados pela economia norte-americana e pelo dólar, as suas respectivas posições dentro da hierarquia mundial permaneceram sólidas, pelo menos até a eclosão da crise financeira em 2007.

Este trabalho procura discutir em que medida esta crise representa um ponto de inflexão, que acelera tendências antagônicas pré-existentes, quanto ao papel do dólar enquanto reserva internacional. A crescente literatura sobre o assunto aponta para a existência de duas perspectivas: aquelas que argumentam em defesa da manutenção da hegemonia norte-americana e manutenção do status do dólar, e aquelas que apontam um declínio da hegemonia e surgimento de substitutos ou

${ }^{1}$ DECON-UFRGS e PPGEEI-UFRGS. (milan.econ@gmail.com) 
contestadores potenciais para os próximos anos. $\mathrm{O}$ artigo analisa estas questões sem pretender exauri-las. Após esta introdução, a ascensão e hegemonia do dólar americano na economia global são consideradas. Em seguida se discute como a crise financeira afetou o funcionamento global dos mercados financeiros e monetários. A próxima seção discute a possibilidade de rupturas neste padrão hegemônico e o potencial para um declínio do papel do dólar. Em seguida algumas considerações acerca dos impactos do destino do dólar sobre os países em desenvolvimento. A seção final conclui, enfatizando os aspectos que apontam para um declínio lento da hegemonia norte-americana na economia mundial e para a crescente contestação do padrão dólar-flexível.

\section{Ascensão, resiliência e hegemonia do dólar americano}

Fred Block (1977) discute a evolução do sistema monetário internacional enfatizando as relações entre Estados nacionais, com uma polarização entre Europa, principalmente a Grã-Bretanha, e os EUA. O padrão-ouro do final do século XIX e início do século XX criou uma ordem monetária internacional relativamente estável. Esta ordem foi substituída pelo padrão ouro-dólar que se seguiu ao acordo de Bretton Woods no pós-II Guerra, marcando o fim da hegemonia inglesa e a ascensão da hegemonia mundial norte-americana. Nos anos 1970 esta ordem foi destruída a partir dos crescentes déficits externos norte-americanos, inaugurando um período de consolidação do domínio dos EUA. O dólar se converteu na moeda de reserva internacional, conferindo uma grande vantagem e uma fonte de poder para a economia norte-americana.

Por outro lado, a passagem de um regime de câmbio fixo mas ajustável a um regime de flutuação cambial tornou os mercados de moeda e os mercados internacionais de crédito mais voláteis. A resposta dos mercados financeiros ocorreu em seguida, com a criação dos instrumentos derivativos, cujas transações são denominadas em grande parte em dólares. Ao mesmo tempo, a crescente importância dos mercados e instrumentos financeiros, sob controle norte-americano, se traduziu em um descasamento entre economia real e economia financeira, contribuindo para um aumento da especulação em escala global e aumento da fragilidade financeira (Le Monde Diplomatique, 2011, Sweezy, 1987). Por exemplo, houve um rápido crescimento dos instrumentos derivativos em comparação com o produto interno bruto mundial, principalmente nos anos 1980. Esta e outras inovações contribuíram para aumentar a vulnerabilidade e a fragilidade financeira global, com repercussões para o papel do dólar enquanto referência mundial de valor e liquidez, na medida em que o dólar representa um ponto de fuga durante períodos de instabilidade. 
Morgan (2009) discute diversas razões para a resiliência do dólar americano como reserva internacional apesar das frequentes turbulências nos mercados financeiros. Esta robustez se explica, entre outras causas, pela capacidade desta moeda em mitigar os diversos tipos de risco com quais se defronta a economia global, além do papel desempenhado pelas corporações multinacionais originárias dos EUA em utilizar o dólar em suas transações globais. Períodos de crise são acompanhados de fluxos de capitais para o dólar e outros investimentos denominados na moeda norte-americana. A crescente procura por liquidez internacional em dólares, por sua vez, exige saídas de dólares dos EUA, na forma de déficits nas transações correntes com o resto do mundo. E a vantagem de emitir a moeda de reserva internacional permite aos EUA manter estes desequilíbrios crônicos no balanço de pagamentos. Ao mesmo tempo, este mecanismo ilustra uma nova dimensão financeira do imperialismo. Os autores clássicos que elaboraram este conceito deram ênfase à exportação de capital como instrumento de expansão dos países imperialistas. Vasudevan (2009b) aponta para uma reversão recente desta tendência, principalmente pela necessidade norte-americana de financiar seus déficits internos e externos. Morgan também discute as vantagens deste sistema para os EUA, apontadas por Serrano, como a capacidade de determinar as taxas de juros da dívida do país, a possibilidade de desvalorizar a dívida externa por meio de reduções no valor do dólar comparado com outras moeda e o isolamento de flutuações nos preços das commodities, que são fixados em dólares. Outros países teriam então um incentivo em manter o dólar apreciado, e quanto mais comércio e investimentos em dólares, maiores as pressões por comprar dólares e evitar que a moeda norteamericana se desvalorize, em um círculo vicioso que enfraquece os rivais dos EUA e fortalece a posição deste país (Hudson, 2010).

Obviamente, os aspectos monetários e financeiros não são os únicos a sustentarem o domínio norte-americano. Visentini (2004) discute a recente proposta de área de livre comércio das Américas (ALCA) como um dos mecanismos de dominação estadunidense da América e no mundo. Teixeira (1999) descreve o papel dos conflitos bélicos internos (Guerra Civil) e externos (I e II Guerras Mundiais) como parte do processo progressivo de construção e consolidação da hegemonia norte-americana, a partir da mobilização dos enormes potenciais produtivos do país. Todavia, o aspecto monetário e financeiro parece desempenhar um instrumento central no poder norte-americano. Assim, em argumentação similar a Fiori (1999), Hudson (2003) enfatiza o imperialismo monetário com um dos fundamentos da dominação americana. $O$ autor considera as instituições internacionais, principalmente o Fundo Monetário Internacional, como instrumentos de dominação do dólar, com empréstimos denominados nesta moeda, refletindo a situação privilegiada dos EUA no gerenciamento e governança desta instituição. Mas o imperialismo monetário norte-americano, segundo o autor, não se processa, no 
período pós-II guerra, apenas como um padrão-dólar, centrado na moeda, mas um padrão-título do tesouro norte-americano, centrado na dívida pública derivada do financiamento das despesas militares. Tavares e Melin (1997) argumentam no mesmo sentido ao propor o conceito de dólar financeiro como distinto do dólar monetário. Segundo Hudson, entre 1964 e 1968, os EUA financiaram guerras com recursos dos outros países. Induziram falências em outros estados de 1968 a 1970, e provocaram crises monetárias de 1970 a 1972, a partir dos crescentes déficits em transações correntes. No novo século, a antiga estratégia de negligência benigna, onde a potência hegemônica impõe o custo do ajuste de seus próprios desequilíbrios aos demais países, foi adotada novamente. Os déficits tendem a desvalorizar o dólar e prejudicar as exportações mundiais para os EUA. Cerca de $60 \%$ das reservas internacionais são mantidas em dólares ou em ativos denominados (comprados, vendidos e liquidados) em dólares. Os países com dólares então reciclam-nos por meio de compras de títulos do tesouro norte-americano, reforçando o círculo vicioso.

Este padrão sugere uma reduzida sensibilidade do papel do dólar a grandes perturbações na ordem monetária e financeira internacional, sobretudo por meio de mecanismos que se auto-reforçam e se retro-alimentam. Esta resiliência, porém, pode ter sido transformada pela profundidade da crise atual, discutida na próxima seção.

\section{A crise financeira e o papel do dólar}

A crise financeira de grandes proporções que se inicia em 2007, e suas repercussões nos diversos mercados, é comparável apenas à Grande Depressão dos anos 30 (Allen e Moessner, 2011 e Moessner e Allen, 2010). Em função dos mecanismos de funcionamento do padrão-dólar flexível, e a transição do dólar monetário para o dólar financeiro, os mercados de moedas e de derivativos estão fortemente ligados. Baba e Packer (2009) e Baba e Shim (2011) sugerem que a crise financeira gerou turbulência e deslocamentos no mercado de permutas (swaps) de moeda, mercados derivativos intrinsecamente frágeis e voláteis, capazes de transmitir desequilíbrios rapidamente para os ativos (divisas) transacionados nos mercados à vista. $\mathrm{O}$ aprofundamento da crise foi evitado por meio da cooperação entre os bancos centrais, utilizando permutas ou transferências, com a Reserva Federal dos EUA aceitando fluxos de pagamentos em Euros e outras moedas e os demais bancos centrais recendo pagamentos em dólares (Allen e Moessner, 2010). A utilização destes instrumentos pelos bancos centrais novamente reforça e legitima os mecanismos de funcionamento dos mercados financeiros desregulamentados e instáveis, fortalecendo o papel do dólar na economia mundial.

Mesmo que a crise atual tenha diferenças significativas com o evento definidor do capitalismo no século XX, e tenham sido feitos ajustes pelos bancos 
centrais e pelos governos que temporariamente evitaram um colapso similar, existe uma pressão sobre o mercado global de moedas e de ativos financeiros. O papel fundamental desempenhado pelo dólar nos mercados financeiros globais ficou claro novamente durante a crise financeira de 2007. McGuire e Von Peter (2009) discutem a escassez de dólares no mercado bancário internacional que se seguiu à crise, ilustrando a enorme dependência dos mercados financeiros e da economia global dos dólares norte-americanos. Por outro lado, como as transações financeiras têm uma grande sensibilidade às modificações no valor da moeda norte-americana, o que pode vir a desafiar o papel hegemônico do dólar. Ou seja, sendo o dólar a principal fonte de liquidez destes mercados, a escassez desta moeda pode conduzir a uma ruptura completa no funcionamento dos mesmos. Mas a própria manutenção desta assimetria repõe os problemas que conduzem às crises, e a resolução dos mesmos pode vir a transformar radicalcamente o papel do dólar na economia mundial.

Talvez ainda mais importante, a crise financeira abalou tanto o neoliberalismo enquanto regime ideológico informando as políticas econômicas nacionais quanto o sistema financeiro mundial que se sustentou e se expandiu com base na adoção destas medidas. Qualquer tentativa de manter a hegemonia norteamericana sustentada por esta ideologia e na operação global das grandes instituições financeiras norte-americanas, e em menor escala européias, vai encontrar grandes dificuldades. Principalmente pelo fato de os países da periferia capitalista terem condições de operarem em condições de relativa autonomia frente ao centro. Mas em que sentido a crise financeira representa uma transição para uma ordem mundial onde o dólar e a economia norte-americana desempenhariam um papel diferente ou menos importante?

\section{Continuidade e ruptura na hegemonia norte-americana}

Tavares (1997) e Tavares e Melin (1997) discutem a retomada e a reafirmação da hegemonia norte-americana. Os autores não se detém no poder político e econômico dos EUA, ainda que a diplomacia do dólar forte tenha desempenhado um importante papel nos anos 1980, mas principalmente na capacidade do país em moldar as opções políticas e econômicas dos demais países. Por exemplo, as políticas neoliberais, impostas como única opção de política criaram as condições para evitar o desafio alemão e japonês e o surgimento de um mundo policêntrico. Permitiram também a formação de uma nova divisão internacional do trabalho baseada na internacionalização do capital norte-americano. Contudo, os autores não consideram a ascensão da China e o potencial desestabilizador daqueles arranjos, principalmente sobre a possibilidade de desafios ao papel do dólar em função da severidade da crise de 2007. 
Os desequilíbrios financeiros refletem problemas estruturais da economia norte-americana (Morgan, op. cit. e Vasuvedan, 2009a). Neste sentido, a crise simplesmente acelera o declínio e não representa um desequilíbrio conjuntural sem conexão com os profundos problemas estruturais da economia norte-americana, como crescente endividamente, déficits externos e internos, desigualdade e perda da base manufatureira, que conduzem ao círculo vicioso referido acima. Se a crise reflete assimetrias entre os países pela forma como a economia mundial está estruturada, a solução para a mesma, qualquer que seja, não modifica essencialmente as relações econômico-financeiras entre as nações e a assimetria de poder mundial. Particularmente com relação ao dólar, quando o sistema econômico mundial entra em colapso a moeda de reserva internacional é questionada em função desta assimetria entre credores e devedores (The Economic Times, 2012). Isto levanta uma questão acerca da possível existência de alguma independência entre o padrão monetário e o papel do dólar na economia internacional, por um lado, e o poder econômico norte-americano por outro. Seria importante, por meio de um exercício de história financeira, comparar o declínio da libra esterlina nos mercados mundiais com o declínio da hegemonia econômica inglesa. Qualquer que seja a velocidade do declínio, se o mesmo for uma possibilidade, a mudança na estrutura econômica mundial deve conduzir necessariamente a uma transformação no papel do dólar.

Como os estudos de Tavares e Melin avançam a discussão até meados da década de 1990, seria importante entender como a crise pode representar um desajuste que não coloca em questão a hegemonia norte-americana e o papel do dólar. Aqui a referência é o estudo de Fiori (2008). Ele argumenta que o colapso do poder norte-americano é um mito. Os EUA dominam e controlam a economia global, o regime monetário, o sistema financeiro, a tecnologia, as comunicações e o poder militar. Segundo Fiori o sistema mundo se encontra em contínua em expansão em termos de incorporar novos Estados no núcleo de poder, intensificando a concorrência imperialista entre EUA, China e Rússia, mas criando interdependências que unificam os países no núcleo dominante da economia mundial. Fiori considera o papel da China e postula a possível fusão entre o capital financeiro chinês e o norteamericano. Há mesmo a possibilidade de criação de poderes regionais centrados na Índia, Brasil, Irã e África do Sul. Fiori rejeita a existência dos ciclos hegemônicos, onde um Estado substitui um outro na irradiação do dinamismo capitalista. O sistema-mundo se expanse continuamente, gerando episódios de crise, guerra, desaceleração econômica mas também estabilidade, paz e crescimento. A crise, assim como a guerra, é gestada pela expansão bem sucedida da potência hegemônica, com a incorporação de novas potências econômicas mundiais.

Se se entende o colapso no sentido de uma crise abrupta, de fato a hegemonia norte-americana seria improvável. Porém, o declínio, mais lento e gradual, poderia 
ser uma possibilidade. O poder central pode ser desafiado, reduzindo a hegemonia mas mantendo a posição no núcleo duro da economia global, que declina lentamente. O controle da economia, da política, da força militar também caracterizaram a hegemonia de outros países em outros períodos, como por exemplo a Inglaterra no século XX, Espanha e Portugal no século XVII. E todos estes impérios perderam força e foram substituídos por um novo poder. Da mesma forma, a II Guerra reduziu o poder da Alemanha e do Japão, e aumentou o poderio norte-americano e dos aliados, sem devolvar à Inglaterra e à libra esterlina o privilégio da hegemonia mundial. Não houve expansão balanceada do núcleo de poder, e o crescimento e recuperação da Europa se deu de forma subordinada aos EUA, principalmente por meio do Plano Marshall. A data de publicação do estudo de Fiori sugere que os efeitos plenos da crise, e o prolongamento da mesma, ainda não haviam sido sentidos. A crise neste caso também pode reforçar o crescente dinamismo da economia chinesa. A fusão entre os capitais nacionais discutida por Fiori só ocorreria com liderança norte-americana, dado o veto explícito à compra de ativos estratégicos dos EUA por parte da China. Dificilmente a China aceitaria a posição subordinada quando os EUA se encontram enfraquecidos e a China tem recursos excedentes. Mais provável seria a fusão de capitais asiáticos e a formação de um conglomerado financeiro oriental que pudesse dar sustentação à expansão econômica chinesa e dos tigres asiáticos sem depender do veto norte-americano. A perspectiva de Fiori é ampla e não permite visualizar o papel específico do dólar. Fica implícito que a manutenção do poder norte-americano, ainda que transformado pela concorrência interestatal, deve se refletir na manutenção do dólar como reserva internacional.

Stephen Cohen e Brad Delong (2009) levantam dúvidas sobre a validade do ceticismo com relação à perda de supremacia pelos EUA. Eles argumentam, assim como Teixeira (op. cit.), que a segunda guerra mundial foi instrumental na consecução dos objetivos norte-americana. $O$ governo procurou enfraquecer o papel da Grã-Bretanha e só então entrou no conflito e promoveu auxílio para os aliados. Ao final do conflito, os EUA tinham o dinheiro e a Grã-Bretanha não. Os empréstimos feitos pelos EUA para a reconstrução européia tinham de ser repagos em dólares. $O$ dinheiro norte-americano ajudou a solidificar um ideário neoliberal como o modelo norte-americano, influenciando sutilmente o comportamento de outras nações e reduzindo a necessidade do uso da força militar. $O$ domínio cultural foi financiado com a pujança econômica e o controle da moeda internacional. Hoje em dia a situação se inverteu, e os outros países têm o dinheiro, o que conduzirá ao fim de influência dos EUA, tal como existira antes da crise.

Segundo os autores, na conjuntura atual os EUA ainda mantém uma posição relativamente privilegiada do ponto de vista econômico, financeiro, tecnológico, comercial e militar. Mas a situação de aperto financeiro persistirá em função do 
elevado endividamento público e privado. Investidores estrangeiros adquirem ativos nos EUA, mas os títulos da dívida estão nas mãos de governos asiáticos, principalmente fundos de riqueza soberana: China com US\$ 2,5 trilhões, Japão comUS\$ 1 trilhão e Taiwan, Hong Kong, Cingapura e Coréia do Sul com US\$700 bilhões. Os ativos considerados estratégicos, como recursos naturais, energéticos e minerais permanecem bloqueados para investidores de outros países, principalmente a China. Estas reservas em ativos atrelados ao dólar modificariam o balaço de poder em favor da Ásia. Contudo, os autores notam que qualquer variação significativa nas taxas de câmbio vão afetar o valor dos ativos e também a balança comercial entre os países, criando uma interdependência. Da mesma forma, o neoliberalismo ficou desacreditado e há mais espaço para política industrial do tipo perseguido pelos países Asiáticos.

Morgan (2009) discute as vunerabilidades associadas ao padrão dólar flexível em função da estrutura econômica dos EUA e também das relações entre EUA e China. Somadas à instabilidade financeira que deriva da própria economia norteamericana, mais desigual e mais produtiva, com a diferença sendo paga na forma de dívida, estas vulnerabilidades tendem a contribuir para uma crise de confiança e a perda de poder do dólar. Morgan nota que o dólar americano tem experimentado um longo período de desvalorização. $O$ crescente endividamento norte-americano é visto por Morgan como uma fonte de vulnerabilidade, além da crescente dependência de importações e da China enquanto fonte de fundos. A China possui o segundo maior estoque de títulos da dívida pública norte-americana e o maior estoque de dólares como reserva internacional. Há conflitos sobre as relações comerciais, problemas geoestratégicos sobre fontes energéticas, a taxa de câmbio desvalorizada do Yuan e questões sobre a própria estabilidade econômica e social da China. A possibilidade de canalizar fundos para o desenvolvimento de um mercado financeiro robusto na Ásia não está descartada, segundo o autor.

Mesmo que os argumentos de Cohen, Delong e Morgan apontem para uma mudança na hegemonia norte-americana e no papel do dólar na economia mundial, Teixeira (op. cit.), escrevendo antes da crise, argumenta que um possível enfraquecimento dos EUA não conduz necessariamente à formação de uma nova ordem internacional ou de um novo centro cíclico hegemônico, mas à instabilidade e crise. O autor considera a possibilidade de um quarto estágio na retomada da hegemonia, depois que a elevação da taxa de juros no final dos anos 70 deu sobrevida ao domínio norte-americano a partir da valorização do dólar e dos desequilíbrios financeiros que provocou nos demais países desenvolvidos. Teixeira reconhece que os desequilíbrio que surgiram nos anos 60 e 70 enfraqueceram a posição externa do país e que houve apenas um fortalecimento temporário nos anos 80 e 90. 
O argumento que fundamenta o declínio do dólar e da economia norteamericana foi fornecido por Giovanni Arrighi (1999). Em sua interpretação, a história sugere a existência de ciclos sistêmicos de acumulação, onde Estados nacionais assumem um papel de liderança na condução da economia global a partir de um centro hegemônico. $O$ ciclo tem uma fase ascendente caracterizado por uma expansão da produção e uma fase de declínio quando as finanças passam a predominar. $O$ ciclo explica a sucessão de potências hegemônicas na economia global: Holanda, Grã-Bretanha, EUA e Ásia. Ou seja, o declínio do ciclo hegemônico norteamericano, após um período de expansão produtiva, passaria por uma crise financeira, ao mesmo tempo em que um novo centro surge com uma fase ascendente de expansão material da produção. A ascensão da China como centro dinâmico da economia global e os desafios ao domínio norte-americano depois da crise de 2007 tornam os argumentos de Arrighi mais fortes, ainda que a história não tenha um padrão de regularidade e repetição linear tão preciso quanto o sugerido por sua interpretação. E a recente pressão chinesa para a substituição do dólar como reserva internacional é um outro aspecto a ser considerado.

\section{Os impactos nos países do Sul}

A evidência empírica sobre padrões de produção e comércio sugerem que o centro dinâmico da economia mundial parece se deslocar cada vez mais para a Ásia, apesar da relativa estagnação da economia japonesa. A economia dos países do Sul segue sendo mais dinâmica, acentuando a estagnação relativa dos países avançados, ainda que a instabilidade financeira no centro tenha repercussões reais na periferia. Por exemplo, a economia brasileira encolheu em 2009 e o ritmo de crescimento na periferia como um todo foi reduzido. Contudo, do ponto de vista geo-estratégico, Fiori (2008) argumenta que a crise vai intensificar a competição entre Brasil e EUA na América do Sul. Um outro fator que sugere um enfraquecimento relativo da posição norte-americana é a crescente rejeição, por parte de muitos países periféricos, aos programas de ajuste do FMI e do Banco Mundial² ${ }^{2}$

Uma outra mudança se apresenta nos fluxos mundiais de capital. Segundo Vasudevan (2009a), houve três ondas de fluxos de capital privado para os países em desenvolvimento: nos anos 1960 com o desenvolvimento dos Euromercados e a reciclagem dos petrodólares, até a crise da dívida dos anos 1980. A segunda com as reformas neoliberais de liberalização e desregulamentação nos anos 1990, até a crise Asiática de 1997-98, e a terceira no período que se inicia em 2002. Nos dois primeiros

\footnotetext{
2 Mas ao contrário do que aconteceu no imediato pós-Guerra com relação aos países devedores, primariamente periféricos, não se exige dos EUA um ajuste similar, com contração e austeridade.
} 
os fluxos eram compatíveis com saídas líquidas de capital dos EUA, mantendo a liquidez internacional, mas exportando fragilidade e crises para a periferia (95 crises ao todo), ao mesmo tempo em que o papel hegemônico do dólar era preservado quando a crise impunha o dólar como um porto seguro. Na última onda houve reciclagem dos excedentes comerciais dos países periféricos, ajudando na formação da bolha especulativa e na crise das hipótecas nos EUA. A crise alterou a direção dos fluxos e completou a terceira onda. Herrmann and Mihaljek (2010) mostram uma redução no fluxo de empréstimos bancários para os países menos desenvolvidos durante a crise financeira internacional.

As evidências sugerem que é o conflito com a China que vai redefinir a ordem econômica mundial pós-crise e o papel do dólar com instrumento de manutenção da hegemonia norte-americana. $\mathrm{O}$ principal desafio à hegemonia do dólar vem da China, seguida pela Rússia (NYT, 2009). A oposição é justificada em função da fragilidade dos arranjos monetários internacionais e da possibilidade de desvalorização do dólar em função dos elevados déficits externos dos EUA. O presidente do banco central chinês defende a criação de uma nova moeda de reserva internacional. O país defende a adoção dos direitos especiais de saque gerenciados pelo Fundo Monetário Internacional. Já se discute mesmo a possibilidade de o Yuan substituir o dólar (The Economic Times, 2012). A razão apresentada é que na configuração atual o sistema apresenta muitas fragilidades e tendência ao desequilíbrio, criando riscos sistêmicos. De fato, a quantidade de crises financeiras de diversos tipos tem acelerado nas últimas décadas. Por outro lado, o problema com o gerenciamento pelo FMI é que esta instituição não é necessariamente neutra, mas reflexo da estrutura e hierarquia do poder econômico e militar mundial, conforme argumenta Hudson (op. cit.). As negociações para a criação do fundo refletiram a ascensão norte-americana e o declínio britânico na economia mundial. A reforma da governança das instituições internacionais no sentido da uma maior participação e representatividade dos países menos desenvolvidos seria um passo necessário para que a influência norteamericana fosse reduzida e a China tivesse um papel mais importante.

O ajuste da economia global tem desafios que refletem a atual hierarquia de poder. Resgatar a idéia original de Keynes, onde tanto os países credores como os países devedores deveriam se ajustar, com os primeiros cortando a dependência externa e voltando-se para dentro e o últimos reduzindo o endividamento, exige um equilíbrio de poder político e econômico que não existe atualmente. Porém, na medida em que estas instituições sejam um espaço de conflito e contestação, a crise financeira pode facilitar o processo de reforma e fortalecimento da multilateralidade para além da retórica. Da mesma forma, os direitos especiais de saque são calculados tendo por base o valor do dólar norte-americano, do euro, da libra esterlina e do iene, ou seja, reflete o valor da moeda dos países do centro de poder. Uma possível fuga do 
dólar teria fortes implicações para o financiamento da economia norte-americana, tanto para o setor público como para o privado, e qualquer medida implementada neste sentido será um componente adicional na aceleração do declínio da potência. (The Guardian, 2010). Da mesma forma, a reciclagem dos dólares adquiridos pela China no mercado de ativos nos EUA pode ter contribuído para a bolha especulativa, seguindo um padrão experimentado por outras crises recentes (Vasudevan, 2009a). Ou seja, a crise também reflete a expansão chinesa, levantando dúvidas sobre o argumento de Fiori que a crise é gestada pela potência hegemônica.

Isso sugere que a economia global não pode abrir mão dos déficits norteamericanos, mas também não pode se ajustar sem maiores problemas ao mesmo, já que o ajuste exigiria uma redução dos excedentes chineses que, de um ponto de vista contábil, requerem déficits em alguma outra parte do mundo, configurando o assim chamado 'Bretton Woods renovado'. Medidas protecionistas podem ser uma resposta, da mesma forma que a Lei Smoot-Hawley elevou as tarifas para defender a produção doméstica norte-americana no início da Grande Depressão dos anos 1930. E mesmo uma valorização da moeda chinesa não teria um impacto muito forte na economia norte-americana, dado o desmantelamento industrial produzido por três décadas de neoliberalismo. Ainda, segundo Hudson (2010) a valorização do Yuan não resolve o problema do elevado endividamento das principais economias, principalmente os EUA, que está na origem da fragilidade monetária dos demais países, bem como os problemas estruturais da economia norte-americana, derivados do financiamento dos gastos militares e dos fluxos de capitais para o exterior em função da baixa remuneração doméstica durante períodos de normalidade. Além disso, argumenta Hudson, a balança comercial chinesa só responderia a uma desvalorização massiva do dólar. Outras respostas incluem ampliar o crédito doméstico chinês, com o risco de criar bolhas especulativas, comprar ativos estrangeiros no exterior, que enfrenta restrições nacionalistas, ou comprar ativos estrangeiros na China. Hudson defende a última opção como defesa contra uma possível intensificação protecionista e as proibições de aquisição chinesa de ativos considerados estratégicos nos EUA. Mas Hudson também argumenta que a acumulação de reservas na China resulta não apenas de superávits comerciais, mas de um influxo especulativo para valorizar o Yuan e desvalorizar os ativos em moeda estrangeira, com a diferença sendo embolsada pelos especuladores. Novamente a predominância financeira recolocando a centralidade do dólar, mas de forma contraditória e com sinais de crescente insatisfação com o status quo.

O jornal the economic times (2012) relata a existência de uma inércia na manutenção do dólar em função do emprego massivo desta moeda como instrumento de transações internacionais ou mesmo como unidade de conta utilizada nos contratos internacionais. Essa inércia impediria a substituição da moeda americana 
no curto prazo. Como resposta, uma guerra cambial se seguiu à cooperação durante os períodos de maior severidade da crise (Financial Times, 2010). A guerra cambial foi a resposta dada até o momento para solucionar os problemas derivados da crise e dos desequilíbrios gerados pela assimetria de poder na economia global. Os bancos centrais dos EUA, Japão e Grã-Bretanha adotam medidas de facilitação quantitativa, com expansões monetárias que desvalorizam as moedas nacionais. Medidas não enfrentam os problemas estruturais e que mantém o problema central: a assimetria de poder que mantém o dólar como reserva internacional ao preço de desequilíbrios e crises financeiras crescentes, mas que ao mesmo temo sugerem um enfraquecimento gradual do poder do dólar na medida em que os desequilíbrios desestruturam a economia norte-americana e um novo pólo dinâmico se fortalece na Ásia.

\section{Conclusão}

O possível declínio do dólar, lento e gradual, como reflexo da perda de dinamismo da economia norte-americana e dos múltiplos desequilíbrios financeiros daí derivados, deve levar a uma lenta reconfiguração da estrutura econômica mundial. A ascenção da China e o dinamismo de algumas economia periféricas, em conjunto com o declínio do poder norte-americano apontam no sentido de um maior multilateralismo nas relações econômicas e modificações na estrutura da governança global. A possível existência de ciclos sistêmicos de acumulação sugere que eventualmente os centros dinâmicos da economia global são substituídos, após um ciclo sistêmico de acumulação onde as as crises financeiras desempenham um papel na perda de hegemonia da potência dominante. A crise financeira recente, ainda que reforce o papel do dólar enquanto reserva, pode representar uma inflexão, acelerando a transição para um ciclo sistêmico de hegemômia Asiática, onde processos de produção material ocorrem de forma acelerada. O dólar parece ser desafiado pela primeira vez, e o desafio tem o lastro de uma forte expansão material que se reflete em uma rápida acumulação de poder financeiro, até o momento ainda com base na moeda dominante. Existem evidências que, de fato, há perda de influência e um processo gradual de redução do poder americano paralelamente à ascensão da China. Esses dois aspectos, fundamentados por uma severa crise financeira, sugerem uma modificação estrutural na economia global. Como a ruptura financeira acelera a transição mas não deflagra uma crise econômica de maiores proporções no estilo da Grande Depressão, de uma única vez, mas ao invés, por meio de uma sucessão de crises de diversos graus de severidade, a perda de hegemonia se dá de forma lenta e gradual, permitindo que se sustente dúvidas sobre a perda da hegemonia americana no curto e médio prazos, mas dirimindo cada vez mais as dúvidas sobre a sua potencialidade no longo período. 


\section{REFERÊNCIAS}

Allen, William A. and Richhild Moessner (2010) Central bank co-operation and international liquidity in the financial crisis of 2008-9. Bank for International Settlements Working Paper $n^{\circ} 310$.

(2011) The international propagation of the financial crisis of 2008 and a comparison with 1931. Bank for International Settlements Working Paper $n^{\circ} 348$.

Arrighi, Giovanni (1999) The Long Twentieth Century - Money, Power, and the Origins of Our Times. New York: Verso.

Baba, Naohiko e Frank Packer (2009) From turmoil to crisis: dislocations in the FX swap market before and after the failure of Lehman Brothers. Bank for International Settlements Working Paper $n^{\circ} 285$.

Baba, Naohiko and Ilhyock Shim (2011) Dislocations in the won-dollar swap markets during the crisis of 2007-09. Bank for International Settlements Working Paper $n^{\circ} 344$.

Block, Fred (1977) The Origins of International Economic Disorder: A Study of United States International Monetary Policy from World War II to the Present. Berkerley e Los Angeles: University of California Press.

Cohen, Stephen e Brad Delong (2010) The End of Influence - What Happens When Other Countries Have the Money. Basic Books.

Financial Times (2010) IMF chief warns on exchange rate wars. 5 de outubro.

Fiori, José Luis (org.) (1999) Estados e moedas no desenvolvimento das nações. Petrópolis: Vozes.

(2008) O sistema mundial, no início do século XXI. In: José Luis Fiori, F. Serrano e C. Medeiros (orgs.) O Mito do Colapso do Poder Americano. Rio de Janeiro: Editora Record.

Herrmann, Sabine and Dubravko Mihaljek (2010) The determinants of cross-border bank flows to emerging markets: new empirical evidence on the spread of financial crises. Bank for International Settlements Working Paper $\mathbf{n}^{\circ} 315$.

Hudson, Michael (2010) Dollar Hegemony and the Rise of China. Disponível: http://michael-hudson.com/2010/07/dollar-hegemony-and-the-rise-ofchina/ Acesso em 9/2/2012.

(2003) Super Imperialism: the origin and fundamentals of U.S. world Dominance. $2^{\text {a }}$ Edição. Londres, Pluto Press. 
Le Monde Diplomatique (2011) Crise bancaire: le casse du siècle. Manière de voir $\mathrm{n}^{\circ}$ 119. Outubro/Novembro.

McGuire, Patrick and Goetz von Peter (2009) The US dollar shortage in global banking and the international policy response. Bank for International Settlements Working Paper $\mathbf{n}^{\circ} 291$.

Moessner, Richhild and William A. Allen (2010) Banking crises and the international monetary system in the Great Depression and now. Bank for International Settlements Working Paper $n^{\circ} 333$.

Morgan, Jamie (2009) How Should We Conceive the Continued Resilience of the U.S. Dollar as a Reserve Currency? Review of Radical Political Economics, March 2009; vol. 41, 1: pp. 43-61.

Serrano, Franklin (2003). From the static gold to the floating dollar. Contributions to Political Economy (22): 87-102.

Sweezy, Paul (1987) Stagnation and Financial Explosion. New York: Monthly Review Press.

Tavares, Maria da Conceição (1997) A retomada da hegemonia norte-americana. In: Tavares, Maria da Conceição e José Luís Fiori (orgs.) Poder e Dinheiro Uma Economia Política da Globalização. $3^{\text {a }}$ Edição. Petrópolis, Vozes.

Tavares, Maria da Conceição e Luiz Eduardo Melin (1997) Pós-escrito 1997: a reafirmação da hegemonia norte-americana. In: Tavares, Maria da Conceição e José Luís Fiori (orgs.) Poder e Dinheiro - Uma Economia

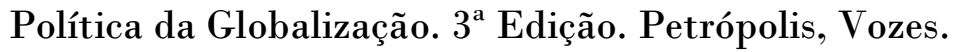

Teixeira, Aloisio (1999) Estados Unidos: A "Curta Marcha" para a Hegemonia. Em: José Luís Fiori (org.) Estados e Moedas no Desenvolvimento das Nações. Petrópolis: Editora Vozes.

The Economic Times (2012) Will Chinese yuan replace US dollar as the global reserve currency? 8 de Fevereiro de 2012.

The Guardian (2010) IMF annual meeting fails to halt slide to currency war. 11 de Outubro.

The New York Times (2009) China Urges New Money Reserve to Replace Dollar. 24 de Março, p. A5.

Vasudevan, Ramaa (2009a) Dollar Hegemony, Financialization, and the Credit Crisis. Review of Radical Political Economics, September 2009; vol. 41, 3: pp. 291-304. 
Vasudevan, Ramaa (2009b) From the Gold Standard to the Floating Dollar Standard: An Appraisal in the Light of Marx's Theory of Money. Review of Radical Political Economics, December 2009; vol. 41, 4: pp. 473-491.

Visentini, Paulo G. F. (2004) The FTAA and US Strategy: A southern point of view. Em: Paulo Visentini and Marianne Wiesebron (eds).Free Trade for the Americas? The United States' Push for the FTAA Agreement. Londres e Nova Iorque: Zed Books. 


\section{RESUMO}

Este artigo discute a hegemonia do dólar na economia mundial. A discussão é feita em três etapas. Em primeiro lugar, o trabalho analisa a evolução do dólar norte-americano na economia mundial, enfatizando a resiliência do mesmo em um cenário de aumento na frequência das crises financeiras. Em seguida o trabalho discute e compara as visões que confiam na manutenção do papel de reserva internacional do dólar com aquelas que assumem um declínio da economia e da moeda norte-americana após a crise financeira que se iniciou em 2007. Finalmente, o artigo levanta algumas consequências da manutenção ou declínio desta hegemonia para os países periféricos.

\section{PALAVRAS-CHAVE}

Dólar Norte-Americano; Hegemonia; Crise; Periferia; 


\section{PARCEIROS}

\section{NERINT}

O Núcleo Brasileiro de Estratégia e Relações Internacionais (NERINT) foi o primeiro centro voltado exclusivamente ao estudo e à pesquisa em Relações Internacionais no sul do Brasil. Foi estabelecido em 1999 junto ao Instituto LatinoAmericano de Estudos Avançados (ILEA) da Universidade Federal do Rio Grande do Sul (UFRGS), Porto Alegre (a cidade do Fórum Social Mundial), Brasil. Seu objetivo sempre foi o estudo crítico e inovador da transformação do sistema mundial após o fim da Guerra Fria. Buscou sempre contribuir para a retomada da discussão de um projeto nacional para o Brasil no plano da análise das opções estratégicas para a inserção internacional autônoma do país, a partir da perspectiva do mundo em desenvolvimento.

$O$ advento de uma "diplomacia ativa, afirmativa e propositiva" no Brasil no início do século XXI veio a convergir com as análises e projeções feitas nos seminários e publicações do NERINT (2 coleções, com 24 volumes). Os estudos exploratórios sobre os novos espaços dos países em desenvolvimento se revelaram acertados, e conheceram notável desenvolvimento. A Cooperação com instituições estatais, empresariais, acadêmicas e sociais foi intensificada, bem como o contato direto com centros na América Latina, África e Ásia, além dos já existentes com a Europa e a América do Norte.

Um dos resultados da nova realidade foi a implantação de um curso de graduação em Relações Internacionais (2004) e de um Programa de Pós-Graduação em Estudos Estratégicos Internacionais (2010), bom como da revista bimestral Conjuntura Austral e da semestral bilíngue Austral: Revista Brasileira de Estratégia e Relações Internacionais. Assim, além da pesquisa avançada, focada prioritariamente nos países emergentes, o NERINT deu origem ao ensino de graduação e pós-graduação diferenciado, além de propiciar intensa atividade editorial. 


\section{PPGEEI}

O Programa de Pós-Graduação em Estudos Estratégicos Internacionais (PPGEEI) iniciou suas atividades em 2011, com cursos de Mestrado e Doutorado. Ele é resultado dos avanços obtidos nas áreas de pesquisa e ensino (Graduação e PósGraduação) na Universidade Federal do Rio Grande do Sul (UFRGS). Possui um corpo de Docentes-Pesquisadores especializado e com experiência Internacional.

Pesquisa: Em 1999 foi criado na UFRGS o Núcleo Brasileiro de Estratégia e Relações Internacionais (NERINT), que realiza pesquisas, seminários e edição de duas coleções de livros e de dois periódicos. Conta também com o apoio do Núcleo de Estudos em Tecnologia, Indústria e Trabalho (NETIT/FCE) e do Centro de Estudos Internacionais de Governo (CEGOV), sediados no Instituto Latino-Americano de Estudos Avançados (ILEA/UFRGS). Em 2004, foi iniciado um curso de Graduação em Relações Internacionais na FCE/UFRGS, em 2005 foi formado o Centro de Estudos Brasil-África do Sul (CESUL) e em 2012 este transformou-se em Centro Brasileiro de Estudos Africanos (CEBRAFRICA). Tudo isto permitiu a formação de uma massa crítica, apoiada em ampla biblioteca especializada.

A tradição de pesquisa que deu origem ao PPGEEI baseou-se numa análise prospectiva das tendências mundiais dos anos 1990. A notável expansão da diplomacia e da economia brasileiras a partir do início do século XXI confirmou a perspectiva adotada, que permitiu a intensa cooperação com os organismos diplomáticos e econômicos internacionais do Brasil. O curso já é uma referência na análise estratégica da inserção das potências emergentes e das relações internacionais Sul-Sul.

A Visão diferenciada do PPGEEI diz respeito, ainda que partindo de fundamentos rigorosamente científico-acadêmicos, à ênfase na dimensão estratégica, teórica e aplicada. Por esta razão, tem sido procurado por estudantes de todo o Brasil e de vários países e tem estabelecido parcerias em todos os continentes. Enfim, um curso focado na compreensão das rápidas transformações pela qual passa o sistema internacional. Publica em parceria com o NERINT as revistas Conjuntura Austral (bimestral) e Austral: Revista Brasileira de Estratégia e Relações Internacionais (semestral e bilíngue). 
O PPGEEI possui três linhas de pesquisa:

\section{Economia Política Internacional:}

Enfoca a Inserção internacional da economia brasileira e de outros grandes países em desenvolvimento na América do Sul, Ásia e África; aborda as características e os efeitos da globalização; e desenvolve estudos comparados e setoriais preocupados com os efeitos da internacionalização de empresas e segmentos produtivos. Especial atenção é dada às crises financeiras internacionais e seus reflexos no Brasil e nos demais países do Sul.

\section{Política Externa e Integração Regional}

Enfatiza a análise do processo de formação, implementação e avaliação de política externa. Procura confrontar padrões de inserção internacional de países estratégicos da América do Sul, África e Ásia, considerando padrões institucionais, política comercial, estruturas de intermediação de interesses e atuação de atores da sociedade civil no eixo Sul-Sul das relações internacionais contemporâneas.

\section{Tecnologia, Estado e Segurança Internacional}

Aborda os principais problemas de segurança no sistema internacional a partir de uma perspectiva que leva em conta os Estados mais poderosos no nível global, mas que introduz de maneira sistemática o problema das balanças regionais de poder, o eixo Sul-Sul, a existência de complexos regionais de segurança e o impacto das tecnologias de informação na Era Digital. 


\section{CENTRO BRASILEIRO DE ESTUDOS AFRICANOS (CEBRAFRICA)}

O Centro Brasileiro de Estudos Africanos (CEBRAFRICA) tem suas origens no Centro de Estudos Brasil-África do Sul (CESUL), um programa estabelecido em 2005 através de um convênio entre a Universidade Federal do Rio Grande do Sul (UFRGS) e a Fundação Alexandre de Gusmão (FUNAG), do Ministério das Relações Exteriores do Brasil. Suas atividades de pesquisa são desenvolvidas junto ao Núcleo Brasileiro de Estratégia e Relações Internacionais (NERINT), localizado no Instituto Latino-Americano de Estudos Avançados da UFRGS.

Em março de 2012 o CESUL foi ampliado para abranger o conjunto geográfico do continente africano, transformando-se em CEBRAFRICA, enquanto a Série Sul-Africana, que publicou cinco livros, foi transformada em Série Africana, com novas obras no prelo. O objetivo segue sendo o mesmo: realizar pesquisas, apoiar a elaboração de teses, dissertações e trabalhos de conclusão, congregar grupos de pesquisa em temas africanos, realizar seminários, promover intercâmbio de professores e estudantes e estabelecer redes de pesquisa e projetos conjuntos com instituições africanas e africanistas, publicar obras produzidas no Brasil ou traduzidas e ampliar a biblioteca especializada fornecida pela FUNAG.

As pesquisas têm por objetivo o conhecimento do continente africano e de suas relações com o Brasil, nas seguintes áreas: Relações Internacionais, Organizações de Integração, Segurança e Defesa, Sistemas Políticos, História, Geografia, Desenvolvimento Econômico, Estruturas Sociais e sua Transformação e Correntes de Pensamento. São parceiros do CEBRAFRICA conceituadas instituições do Brasil, Argentina, Cuba, México, Canadá, África do Sul, Angola, Moçambique, Senegal, Cabo Verde, Egito, Nigéria, Marrocos, Portugal, Reino Unido, Holanda, Suécia, Rússia, Índia e China. As pesquisas em andamento versam sobre a "A presença do Brasil, da China e da Índia na África”, "A África na Cooperação SulSul", "Conflitos africanos", "Integração e desenvolvimento na África", "As relações da África com as Grandes Potencias" e "As relações interafricanas". 


\section{NORMAS DE SUBMISSÃO}

1. A revista AUSTRAL publica artigos científicos e resenhas bibliográficas;

2. A revista está dividida em duas seções: Artigos e Resenhas

3. Os artigos de pesquisa devem limitar-se a 50 mil caracteres (incluindo espaços e notas de rodapé)

e as resenhas bibliográficas devem conter cerca de 4,5 mil caracteres (incluindo espaços) e não devem conter notas de rodapé;

4. As notas de rodapé restringem-se a esclarecimentos adicionais ao texto;

5. A bibliografia deve ser citada de acordo com o sistema Chicago (Autor, data), referenciando a literatura citada ao final do texto;

6. As contribuições devem ser inéditas e podem ser submetidas em português, inglês ou espanhol;

7. As contribuições devem conter o nome completo do autor, sua titulação, filiação institucional (com o nome completo da instituição) e e-mail para contato;

8. O completo preenchimento, pelo(s) autor(es), do formulário de submissão do artigo é

imprescindível;

9. Admite-se a publicação de estudantes de graduação, desde que em parceria com um professor orientador titulado, que constará como autor principal do trabalho.

10. No caso de resenhas bibliográficas, devem ser informados os dados completos e o ISBN da obra analisada;

11. As contribuições devem vir acompanhadas de: 3 palavras-chave em português ou espanhol e 3 key words em inglês; Título em português ou espanhol e em inglês; Resumo em português ou espanhol e Abstract em inglês, ambos com até 50 palavras.

12. As contribuições devem ser feitas através do website da Revista: www.seer.ufrgs.br/Austral.

\section{CONDIÇÕES PARA SUBMISSÃO}

Como parte do processo de submissão, os autores são obrigados a verificar a conformidade da submissão em relação a todos os itens listados a seguir. As submissões que não estiverem de acordo com as normas serão devolvidas aos autores.

1. A contribuição é original e inédita, e não está sendo avaliada para publicação por outra revista; caso contrário, deve-se justificar em "Comentários ao editor".

2. Os arquivos para submissão estão em formato Microsoft Word, Openoffice ou RTF (não possuindo tamanho maior do que $2 \mathrm{MB}$ )

3. URLs para as referências foram informadas quando possível.

4. O texto está em espaço simples; usa fonte Times New Roman de 12-pontos; emprega itálico em vez de sublinhado (exceto em endereços URL); as figuras e tabelas estão inseridas no texto, não no final do documento, como anexos.

5. O texto segue os padrões de estilo e requisitos bibliográficos descritos em Diretrizes para Autores, na página Sobre a Revista.

6. Em caso de submissão a uma seção com avaliação pelos pares (ex.: artigos), as instruções disponíveis em Assegurando a avaliação pelos pares cega foram seguidas. 